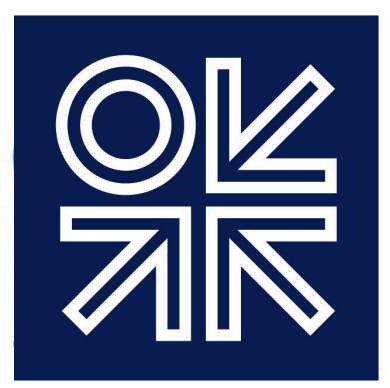

THE OXFORD INSTITUTE

FOR ENERGY STUDIES

February 2018

\title{
A Review of the Evolution of the Japanese Oil Industry, Oil Policy and its Relationship with the Middle East
}

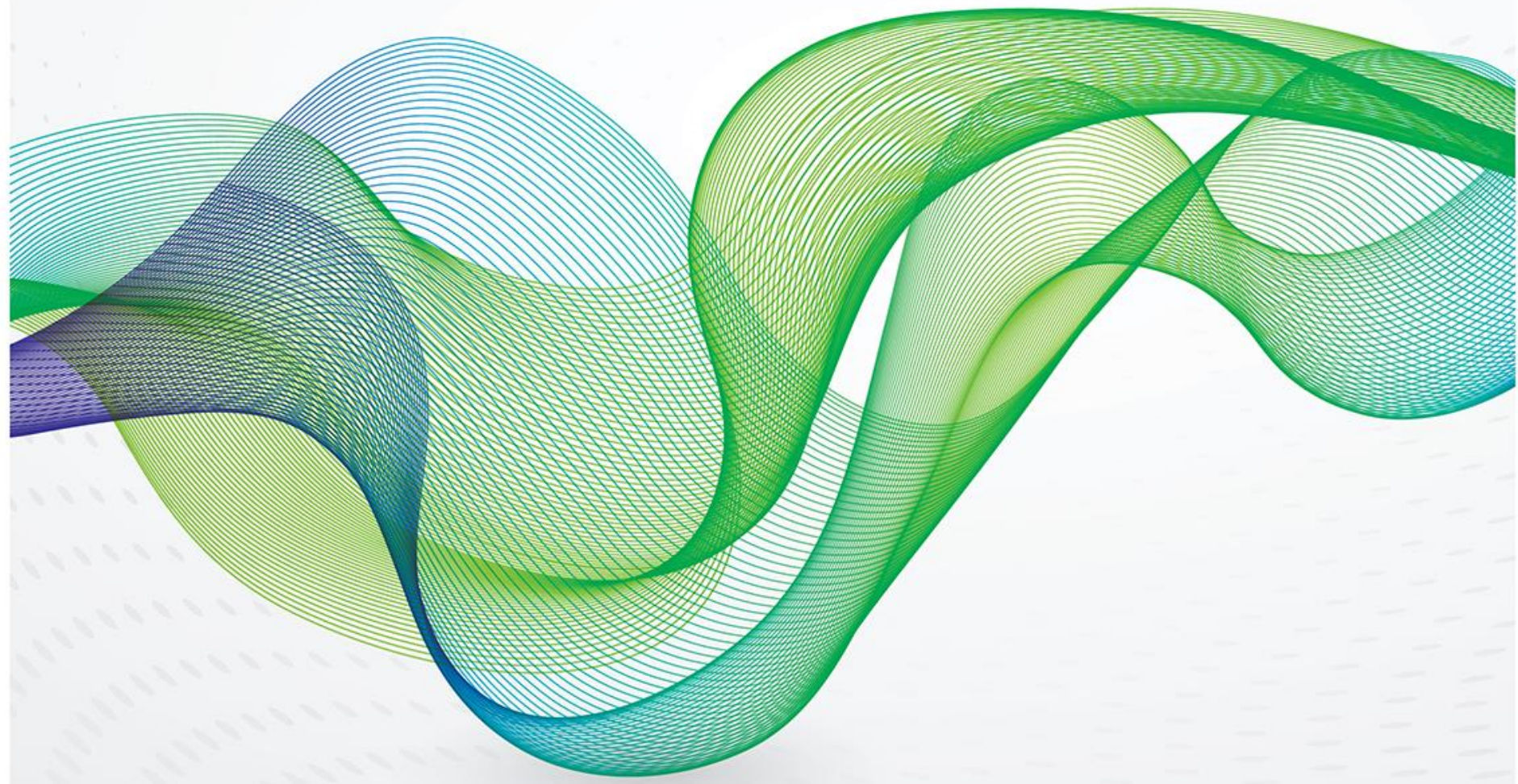



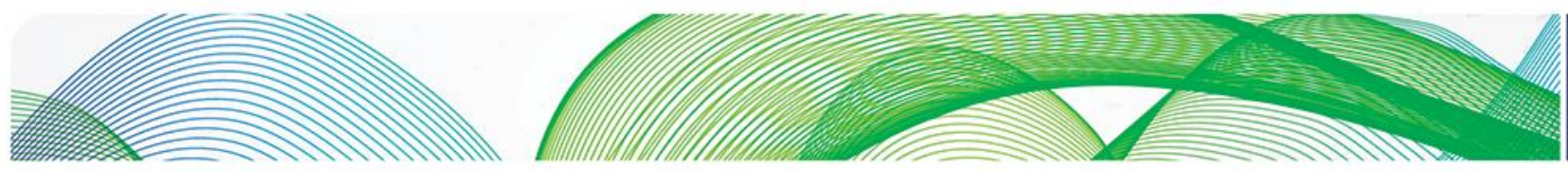

\section{잊조}

The contents of this paper are the authors' sole responsibility. They do not necessarily represent the views of the Oxford Institute for Energy Studies or any of its members.

Copyright (C) 2018

\section{Oxford Institute for Energy Studies}

(Registered Charity, No. 286084)

This publication may be reproduced in part for educational or non-profit purposes without special permission from the copyright holder, provided acknowledgment of the source is made. No use of this publication may be made for resale or for any other commercial purpose whatsoever without prior permission in writing from the Oxford Institute for Energy Studies.

ISBN 978-1-78467-102-0

DOI: https://doi.org/10.26889/9781784671020 

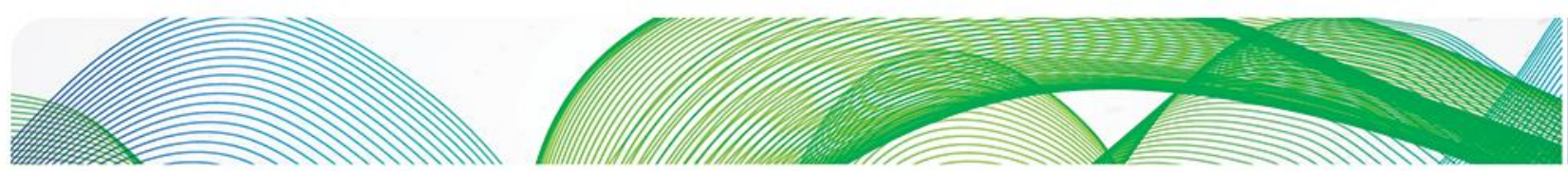

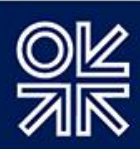

\section{Contents}

Contents. ii

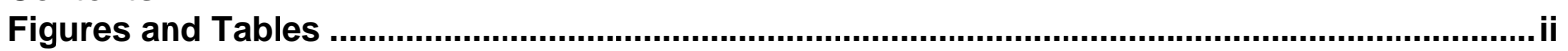

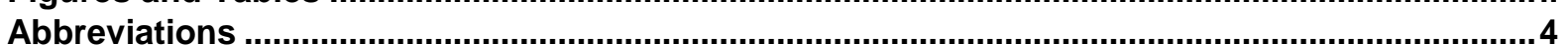

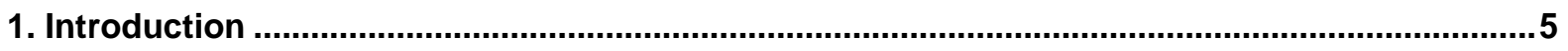

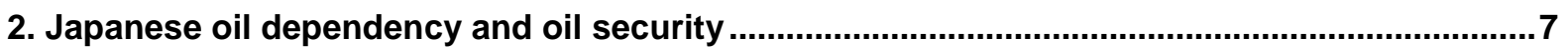

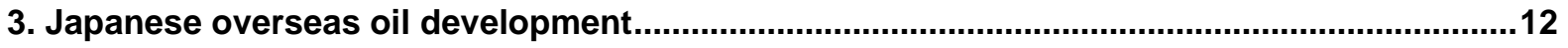

3.1 Support mechanism for overseas oil develop: Japan National Oil Corporation ........................ 13

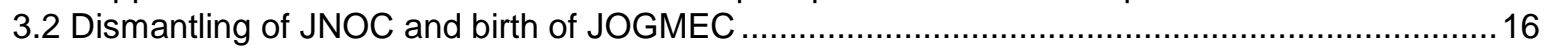

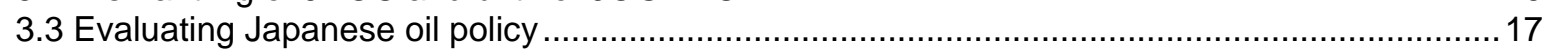

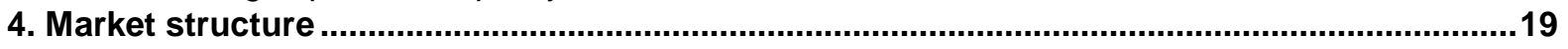

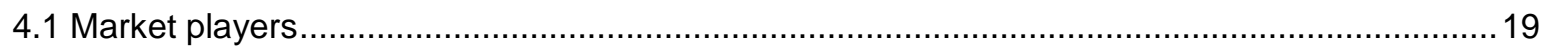

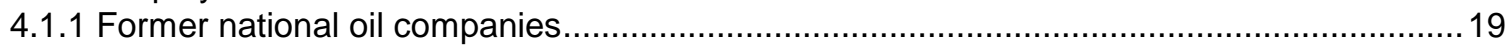

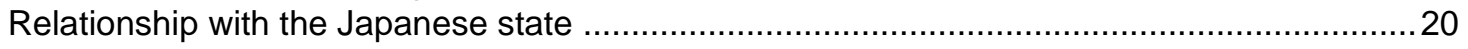

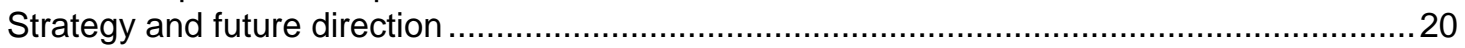

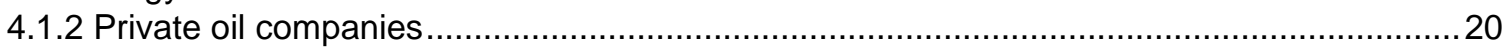

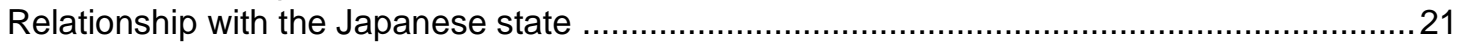

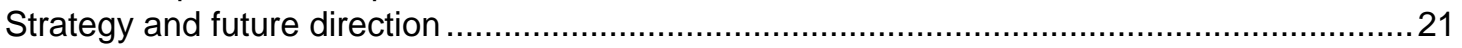

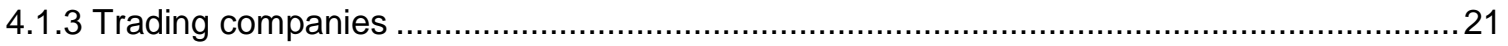

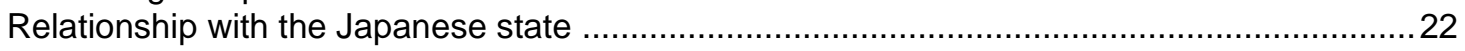

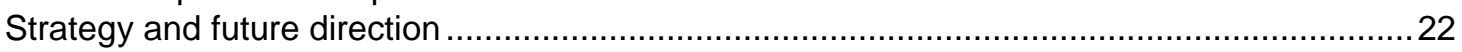

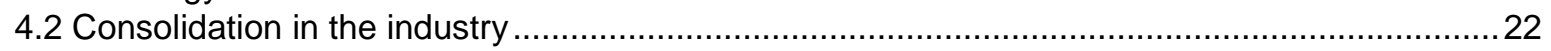

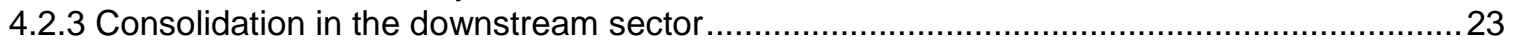

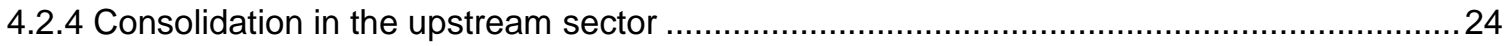

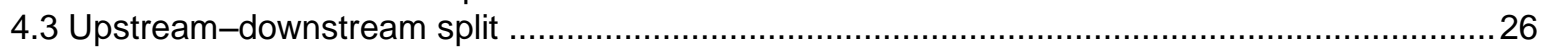

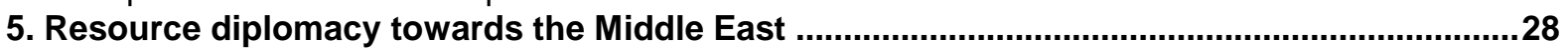

5.1 First phase of resource diplomacy towards the Middle East ..............................................28

5.2 Second phase of resource diplomacy towards the Middle East ..............................................29

5.3 Third phase of resource diplomacy towards the Middle East ............................................... 30

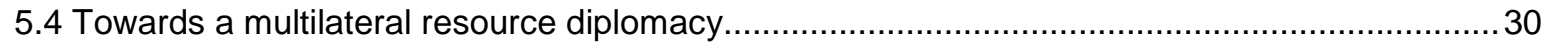

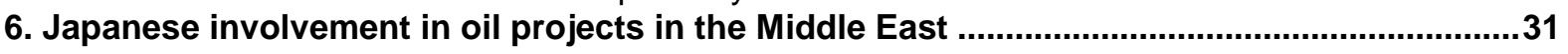

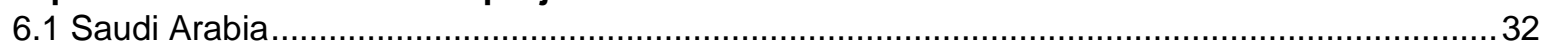

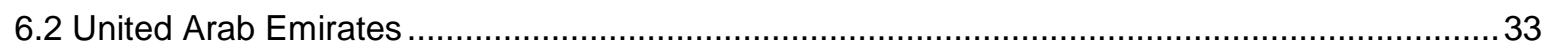

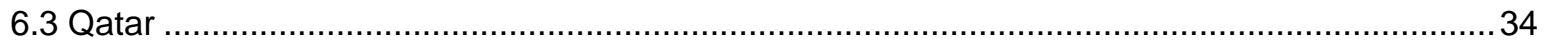

6.4 Other Gulf Cooperation States: Kuwait and Oman ............................................................... 36

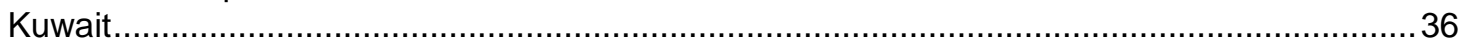

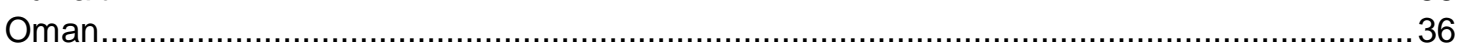

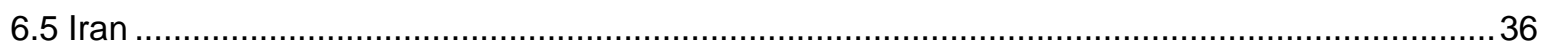

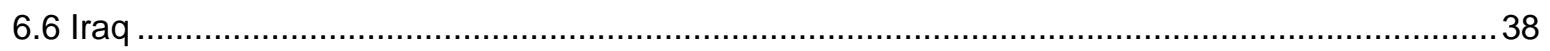

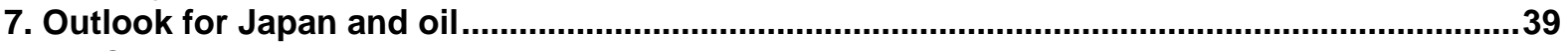

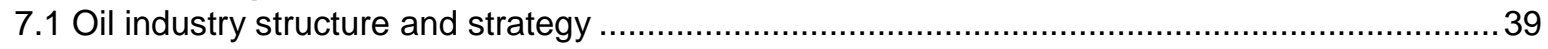

7.2 A more rational oil development policy and policy towards the Middle East .............................40

7.3 How will oil producers ensure their market share in Japan? ................................................. 41

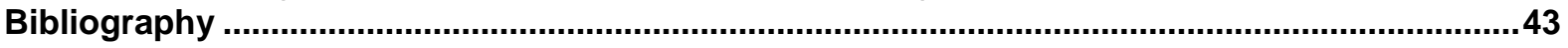

\section{Figures and Tables}

Figure 1: Energy Imports Net (\% of Total Primary Energy Use) - 1965-2015................................. 8

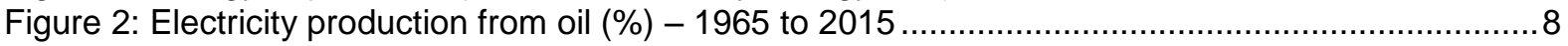

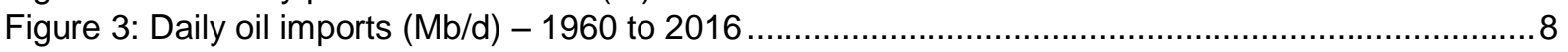

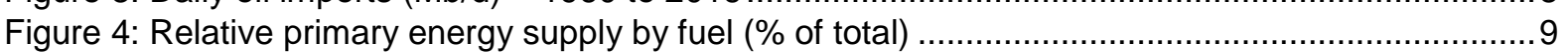

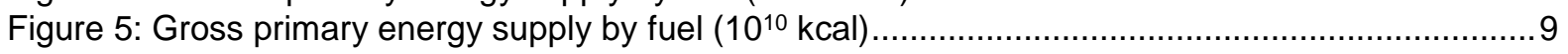



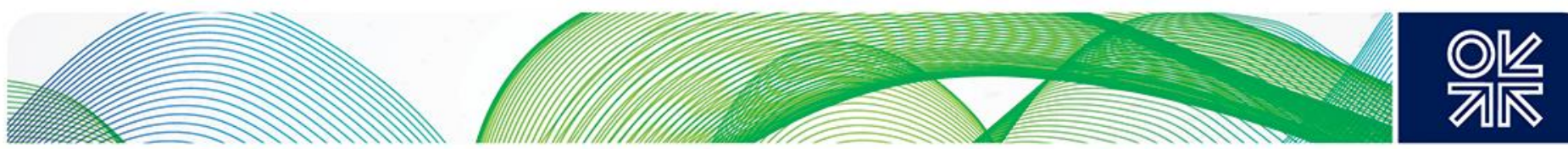

Figure 6: Crude oil imports to Japan (Mb/d) - 1965 to 2030 10

Figure 7: Sources of oil and gas imports in FY 2015 (\% of total gas and \% of total oil) ....................11 Figure 8: Oil imports and Middle East dependency 1960-2015 (million litres of oil per day and \% from the Middle East)

Figure 9: JNOC support in a One Project-One Company consortium .............................................14

Figure 10: Project concession/PCS share (\%) and number of projects $(\#)$................................... 15

Figure 11: Number (\#) of upstream oil and gas projects by region and number of operatorship

(horizontal black line)

Figure 12: JNOC: cumulative equity \& loan contribution and losses (JPY Billion) ...........................16

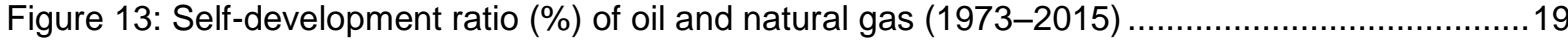

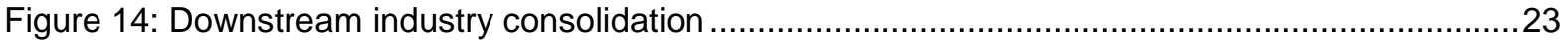

Figure 15: Downstream refining capacity (thousand b/d) and industry refining utilization rate $(\%) \ldots . .24$

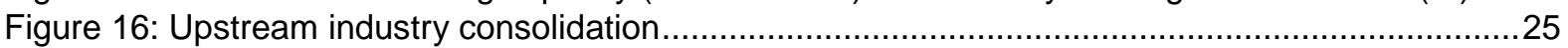

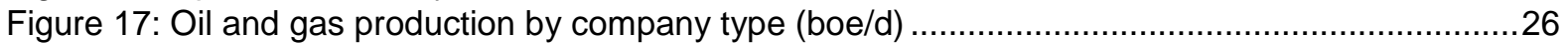

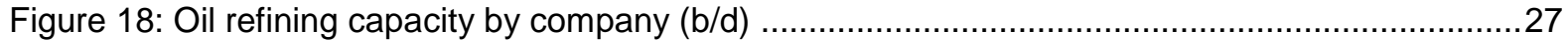

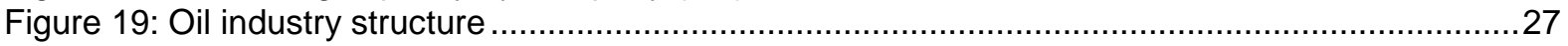

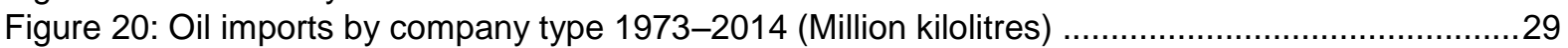

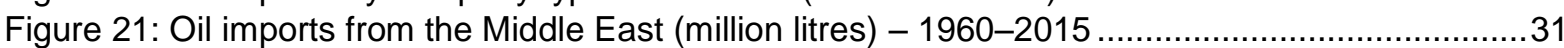

Table 1: Number of projects by acquisition stage based on company type (1979 to 2005) ...............16

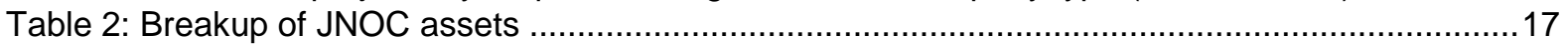

Table 3: Self-development ratio of oil targets and results.................................................... 18

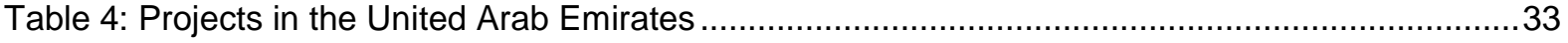

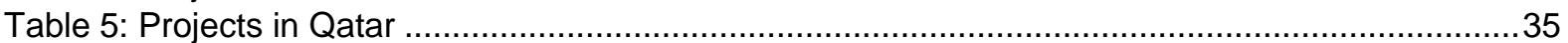

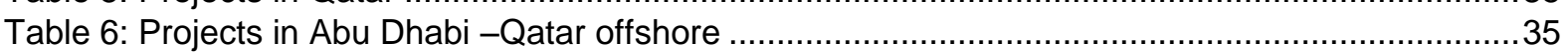

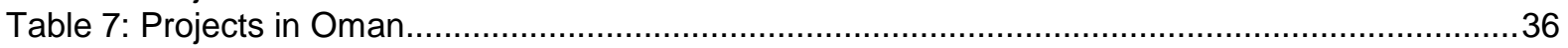

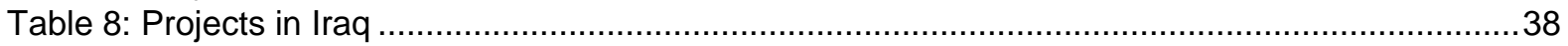




\section{Abbreviations}

\begin{tabular}{|c|c|c|}
\hline ADNOC & - & Abu Dhabi National Oil Company \\
\hline $\mathrm{AOC}$ & - & Arabian Oil Company \\
\hline$b / d$ & - & Barrels per day \\
\hline boe/d & - & Barrels of Oil Equivalent per Day \\
\hline GCC & - & Gulf Cooperation Council \\
\hline JAPEX & - & Japan Petroleum Exploration Co., Ltd. \\
\hline JBIC & - & Japan Bank for International Cooperation \\
\hline JNOC & - & Japan National Oil Company \\
\hline JOGMEC & - & Japan Gas, Oil and Metals National Corporation \\
\hline JPDC & - & Japan Petroleum Development Corporation \\
\hline IOC & - & International Oil Company \\
\hline IPIC & - & International Petroleum Investment Company \\
\hline METI & - & Ministry of Economy, Trade and Industry \\
\hline MENAT & - & Middle East, North Africa and Turkey \\
\hline $\mathrm{Mb}$ & - & Million Barrels \\
\hline $\mathrm{Mb} / \mathrm{d}$ & - & Million Barrels per Day \\
\hline Mboe/d & - & Million Barrels of Oil Equivalent per Day \\
\hline mtpa & - & Metric tonnes per annum \\
\hline MOFA & - & Ministry of Foreign Affairs \\
\hline NEXI & - & Nippon Export and Import Insurance \\
\hline $\mathrm{NIOC}$ & - & National Iranian Oil Company \\
\hline NOC & - & National Oil Company \\
\hline PSC & - & Production Sharing Contract \\
\hline SDR & - & Self-Development Ratio (of oil and/or gas) \\
\hline SPR & - & Strategic Petroleum Reserve \\
\hline
\end{tabular}



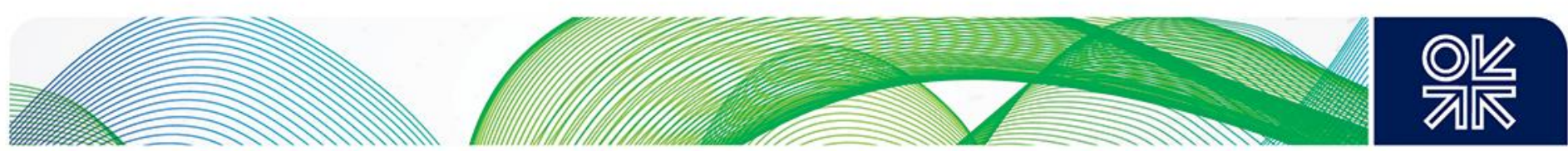

\section{Introduction}

In 2016, Japan was the fourth largest oil consumer in the world (4.037 million barrels per day (Mb/d)), and oil import dependency stood at 99.7 per cent. ${ }^{1}$ OPEC member states in the Middle East supplied 87.2 per cent of total oil imports, with Saudi Arabia (37.4 per cent) and the United Arab Emirates (23.7 per cent) as the primary suppliers. ${ }^{2}$ While Japan's overall import dependency is over 90 per cent for all types of fossil fuels, oil stands out due to the country's high dependence on the Middle East, the low rate of Japanese equity oil, and the lack of realistic short-to-medium term supply diversification options due to geopolitics, geographical isolation, and Japanese oil refinery configurations.

It is therefore not surprising that concerns over oil security and the relationship with the Middle East have impacted the Japanese oil industry and consistently rank high on the agenda of Japanese policymakers. To address these issues, policymakers - with Ministry of Economy, Trade, and Industry (METI) and the Ministry of Foreign Affairs (MOFA) in the forefront - have, since the late 1960s, pursued the following policy measures to enhance oil security and to strengthen the oil industry of Japan:

1) They have attempted to increase the self-development ratio (SDR) of oil, or the share of oil produced by Japanese firms as a proportion of total imports. ${ }^{3}$ This has predominately been done by providing financial support for the overseas exploration activities of Japanese oil companies, through government agencies such as the Japan Gas, Oil and Metals National Corporation (JOGMEC) and its predecessors - Japan National Oil Corporation (JNOC) and Japan Petroleum Development Corporation (JPDC) - and by supporting the so-called national oil projects.

2) Both vertical and horizontal integration in the Japanese oil industry have been encouraged to increase industry competitiveness and bargaining power vis-à-vis oil-producing countries. Industry fragmentation is a frequently cited weakness of the Japanese oil industry, and unlike the position in other major resource-scarce OECD countries, there is no integrated national oil champion in Japan. ${ }^{4}$ Rather the oil industry is vertically and horizontally fragmented and comprised of former national oil companies, private oil companies, and trading companies. ${ }^{5}$

3) A branch of foreign economic policy, referred to as resource diplomacy, ${ }^{6}$ has been practised towards the Middle East. Its goal is to deepen economic interdependency between Japan and oil-producing countries, with the objectives of securing the flow of oil and facilitating concession agreement extensions and the signing of new production sharing contracts (PSC).

The results of these policy measures have been mixed:

- Japan's SDR of oil increased from around 10 per cent in 1973 (447 thousand b/d) to more than 15 per cent (765 thousand b/d) in 2008. ${ }^{7}$ In 2009, METI stopped publishing the SDR of

\footnotetext{
1 BP, 'BP Statistical Review of World Energy,' (BP, 2017); Petroleum Association of Japan, 'Konnichi No Sekiyu Sangyo [in Japanese] [the Oil Industry Today],' (Petroleum Association of Japan, 2017).

${ }^{2}$ METI, 'Enerugi Ni Kan Suru Nenjihoukoku [in Japanese] [Annual Report on Energy],' (Tokyo: METI, 2017)

3 The self-development ratio of oil is defined as follows:

$$
\text { SDR of Oil }=\frac{\text { Total Yearly Oil Production by Japanese Companies }}{\text { Total Yearly Imports of Oil into Japan }}
$$

${ }^{4}$ E.g. Total, France; Eni, Italy; Repsol, Spain \& OMV, Austria. Germany is the only other major OECD country without a dominant domestic integrated oil company.

${ }^{5}$ Masanari Koike, Gento Mogi, and Waleed H. Albedaiwi, 'Overseas Oil-Development Policy of Resource-Poor Countries: A Case Study from Japan,' Energy Policy 36, no. 5 (2008).

6 (j. shigen gaikou)

${ }^{7}$ Author's calculations. In other resource-scarce countries, such as France and Italy, the corresponding oil self-development ratios are 98\% (France) and 55\% (Italy). Source: METI, 'Sogo Shigen Kansakai Bunkakai, Sekiyuseisaku Shoinkai [in Japanese] [Report of Policy Subcommittee of Petroleum Committee, Advisory Committee for Energy],' (Tokyo: METI, 2006).
} 

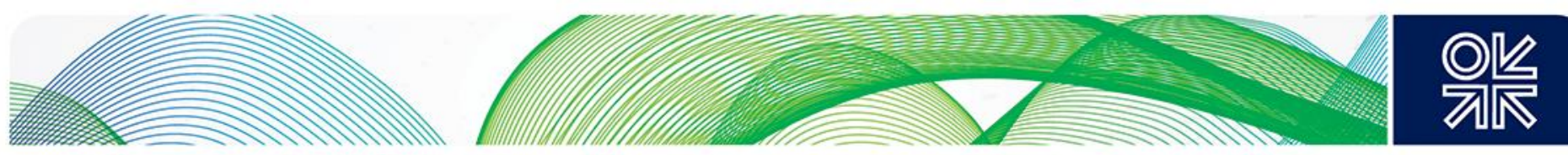

oil and started to jointly measure the SDR of oil and natural gas. In April 2016, this stood at 27.4 per cent (1.467 Million Barrels of Oil Equivalent per Day (Mboe/d)). ${ }^{8}$ Considering a forecasted decrease in oil demand in Japan, together with the start of operations of largescale Japanese-owned floating LNG projects (such as Ichthys, Australia), the SDR is expected to rise. $^{9}$

- Oil industry integration efforts started in earnest in the 1990s and the 2000s, but the upstream-downstream divide is still present. The number of downstream corporate groups consolidated from 17 in the 1970s to four in 2017, and refining overcapacity has been brought down through decommissioning. In the upstream sector, the partially government-owned upstream player INPEX has increasingly taken the role of a core company ${ }^{10}$ in the Japanese oil industry, and a future merger between INPEX and another smaller, partially governmentowned, player, Japan Petroleum Exploration Co. Ltd. (JAPEX), may also be on the table. ${ }^{11}$ Trading companies such as Itochu, Marubeni, Mitsubishi, Mitsui, and Sumitomo remain active in the upstream oil sector, but private oil companies are generally not engaged in new upstream activities.

- It is more difficult to measure the direct impact of Japanese resource diplomacy. Resource diplomacy has evolved from its origins in the immediate aftermath of the First Oil Crisis in 1973 (characterized by a pro-Arab diplomatic stance, loans to oil producers, and panic spot purchases of oil) to a more balanced act of dual dependency on Middle Eastern oil and on the Japanese security relationship with the USA. In recent years, the focus of resource diplomacy has especially been on the Kingdom of Saudi Arabia (KSA), Qatar, and the United Arab Emirates (UAE), and it is unlikely that this will change under current Japanese or US leadership. Rather stronger ties can be expected in particular with KSA and UAE, at the expense of other oil producers. ${ }^{12}$

The objective of this paper is to address an English literature gap on the fourth-largest oil market in the world, the policy determinants that drive it, and the country's relationship with the Middle East. When discussing the Japanese oil industry and the evolution of Japanese resource diplomacy towards the Middle East, together with its future direction, four key factors need to be recognized:

1) Oil security has been, and will remain, a key concern in Japan;

2) Government overseas oil policy and its mechanisms have played an important role in shaping the Japanese oil industry, largely centring on decreasing oil dependency by increasing selfdeveloped oil, sometimes at very high cost;

3) Japanese oil firms are historically fragmented and are, to a varying degree, independent actors with different objectives, capabilities, and relationships both with their own government and with those in oil-producing countries.

4) Resource diplomacy is constrained by the Japan-USA security relationship, but is primarily driven by practical Japanese national and corporate interests.

In the first part of this paper (sections 2 to 4), we will offer an overview of the drivers behind Japanese oil policy, changes in the oil development support mechanism, and the structure of the Japanese oil industry. In the second section (sections 5 and 6), we review the evolution of resource diplomacy and provide an overview of the involvement and investments of Japanese oil companies in the Middle

\footnotetext{
${ }^{8}$ BP; METI, 'Enerugi Ni Kan Suru Nenjihoukoku [in Japanese] [Annual Report on Energy].'

${ }^{9}$ The Ichthys project is expected to produce approximately 500 thousand boe/d.

10 The term 'core company' (j. chukakuteki kigyo) does not connote a national oil company but rather a nationally strategically important company.

Source: A view expressed by several insiders during interviews with the author in Tokyo on 29 September, 29 October, and 31 October 2017.

${ }^{12}$ EDMC, EDMC Handbook of Japan's \& World Energy \& Economic Statistics (Tokyo: The Energy Conservation Center, Japan, 2017); METI, 'Enerugi Ni Kan Suru Nenjihoukoku [in Japanese] [Annual Report on Energy].
} 

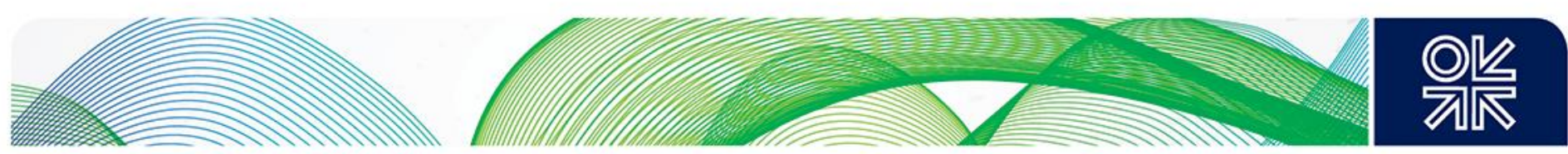

East (Gulf Cooperation Council (GCC), Iran, and Iraq). Lastly, we will discuss the impact of decreased oil demand on the future direction of the Japanese oil industry, its relationship with the Middle East, and how oil-producing countries are attempting to ensure their market share in a shrinking but premium market. ${ }^{13}$

This paper does not seek to provide an exhaustive review of the history of the Japanese oil industry or of the relationship between Japan and the Middle East. Rather, it seeks to provide an overview of the industry and its involvement in the Middle East for members of industry and academia alike.

\section{Japanese oil dependency and oil security}

Considering the long-term decrease in Japanese oil consumption and the current debate on peak oil demand, a preoccupation with oil and assertive resource diplomacy, or concerns about oil supply security, may come across as outdated concepts. Some observers have called energy security a national obsession in Japan. ${ }^{14}$ However, a series of episodes and disasters (such as the Fukushima nuclear accident and the absence of any oil pipeline connections) has enforced a view on the perceived vulnerability of energy supplies among the public and policymakers in Japan. The International Energy Agency also reflects these concerns, while recent Japanese policy briefs on energy call for the continuation of an assertive resource diplomacy, with the view that oil remains a strategic commodity. ${ }^{15}$ The Japanese media and government have also drummed up this view and have recently celebrated the partial extensions of oil concessions in the United Arab Emirates as an important step towards ensuring the future energy security of Japan. ${ }^{16}$

By comparing the case of Japan with other major resource-scarce OECD countries, Japan displays a number of features that justify concerns about oil security. Firstly, Japan's total energy imports as a share of its primary energy use are over 90 per cent; the only other country that comes close to this is Italy, and unlike Japan Italy is connected through a wide pipeline network (see Figure 1). Secondly, until 1975 more than 70 per cent of Japanese electricity was generated with oil, but this figure had fallen to 9 per cent by 2015 (see Figure 2). ${ }^{17}$ And thirdly, in absolute terms, Japanese oil imports are more than twice the French and Italian levels, and around 60 per cent higher than Germany's (see Figure 3).

\footnotetext{
${ }^{13}$ Reuters, 'Saudi Arabia Tightens Its Grip on Japan, Its Biggest Asian Oil Market,' (2017).

${ }^{14}$ Robert A. Manning, The Asian Energy Factor: Myths and Dilemmas of Energy, Security and the Pacific Future (London: Palgrave Macmillan, 2000), as cited in Duffield (2015).

15 The IEA highlights Japan's import dependency and encourages a continued policy of securing overseas oil supplies. IEA, 'Energy Policies of IEA Countries Japan 2016 Review,' (Paris: IEA, 2016).

${ }^{16}$ Sankei, 'Hi No Maru Yuden Keneki Koshin Motomeru - Keizaisho, Abu Dhabi Homon He Kakuryo to Kousho [in Japanese] [a Visit by PM Abe Being Arranged with the Aim of Securing Japanese Oil Rights],' Sankei, 14 January 2017; METI, 'METI and ADNOC Concluded a Basic Agreement on the Extension of Japanese Company's Oil Concessions on the Satah and Umm Al Dalkh Oilfields Offshore from Abu Dhabi That the Company Has Possessed for Forty Years,' METI, http://www.meti.go.jp/english/press/2017/0116_002.html.

17 The share of electricity generated by oil temporarily rose between 2011 and 2014 as oil-fired power plants were brought online following the Fukushima nuclear accident.
} 

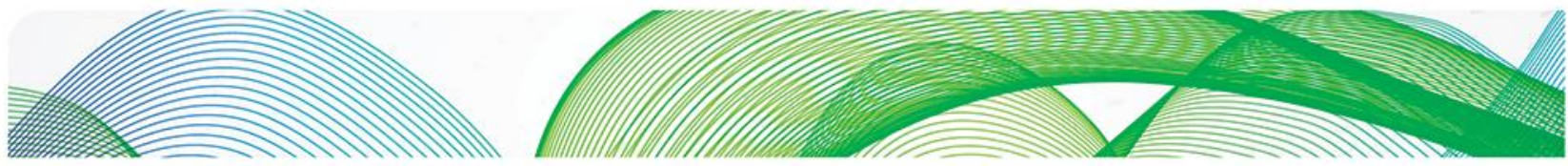

Figure 1: Energy Imports Net (\% of Total Primary Energy Use) - 1965-2015

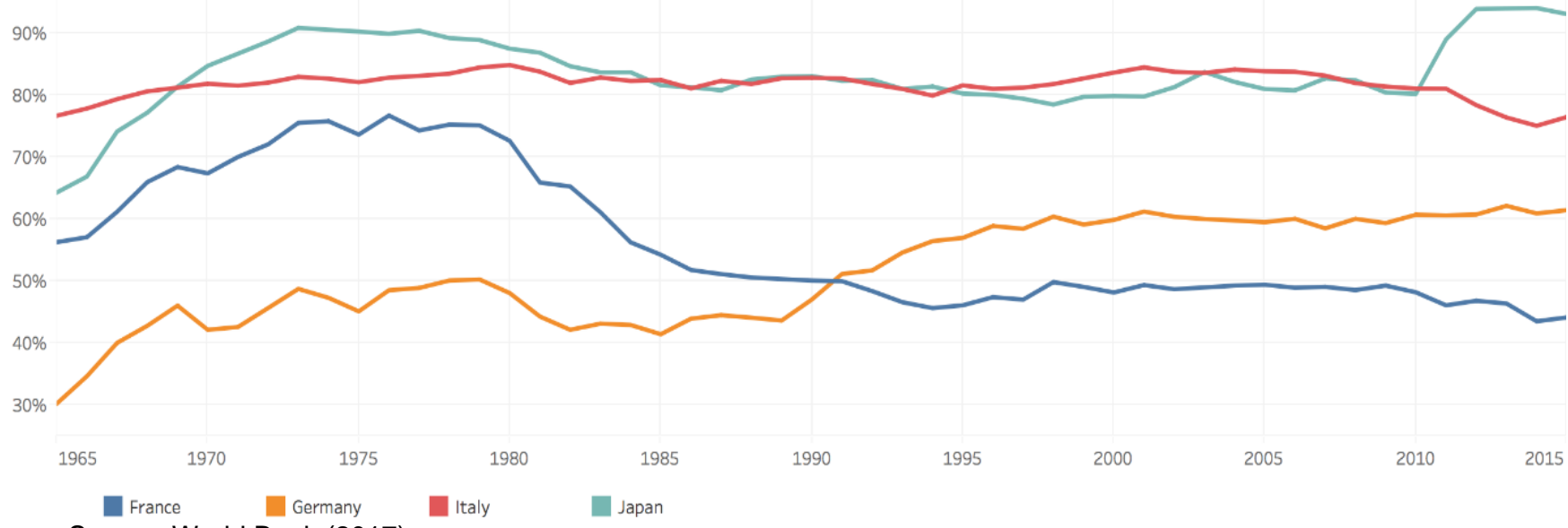

Source: World Bank (2017)

Figure 2: Electricity production from oil (\%) - 1965 to 2015

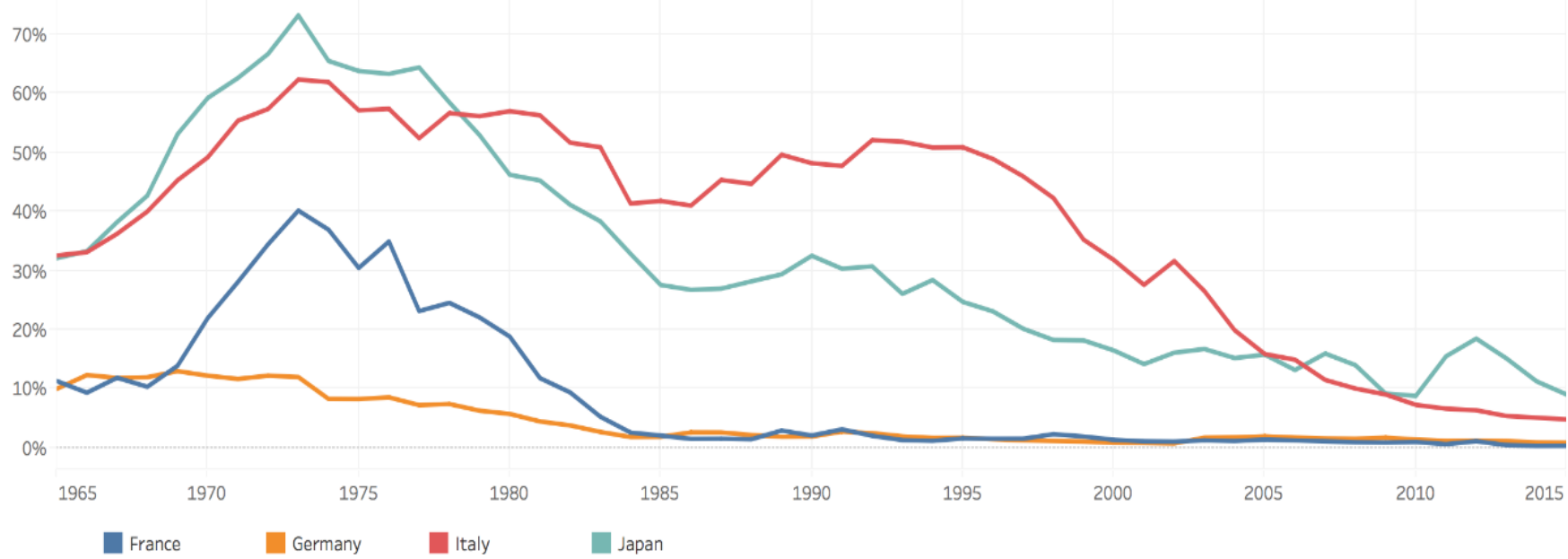

Source: World Bank (2017)

Figure 3: Daily oil imports (Mb/d) - 1960 to 2016

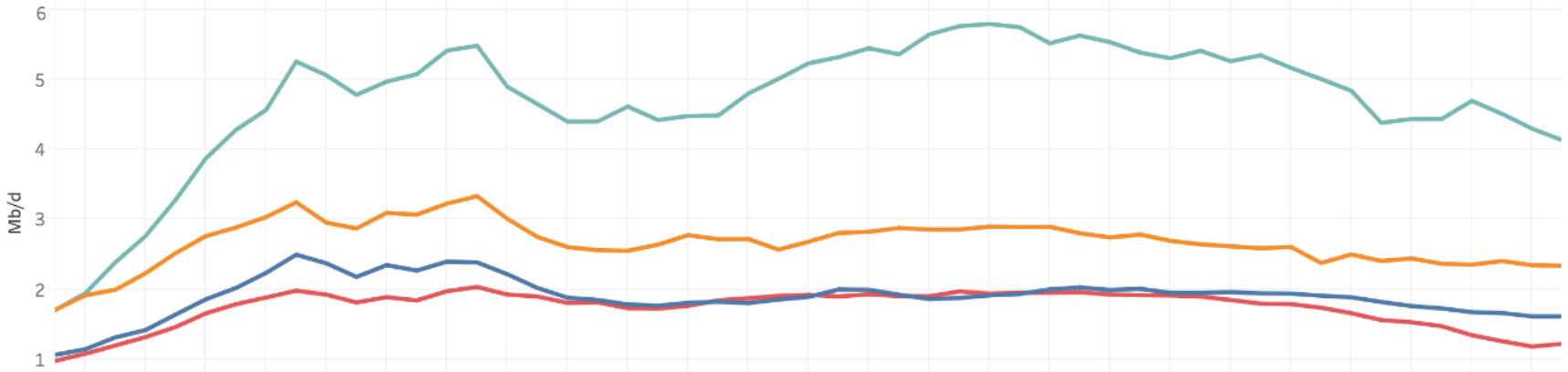

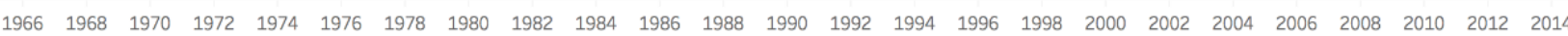

France $\quad$ Germany Italy Japan

Source: World Bank (2017) 

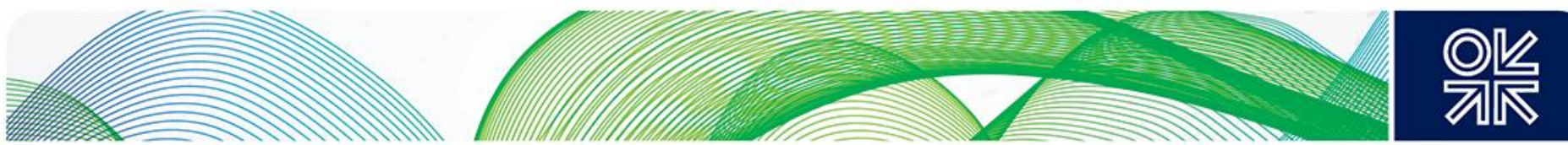

While total oil consumption and the reliance on oil for electricity generation have both decreased, the share of oil in the energy mix still stood at 41.4 per cent in 2016. The main users of oil were industry (38 per cent), transportation (37 per cent), electricity (10 per cent), and residential (6 per cent). Figures 4 and 5 shows how the relative and gross shares of coal, oil, natural gas, nuclear, hydro, and renewables have changed over time: ${ }^{18}$

Figure 4: Relative primary energy supply by fuel ( $\%$ of total)

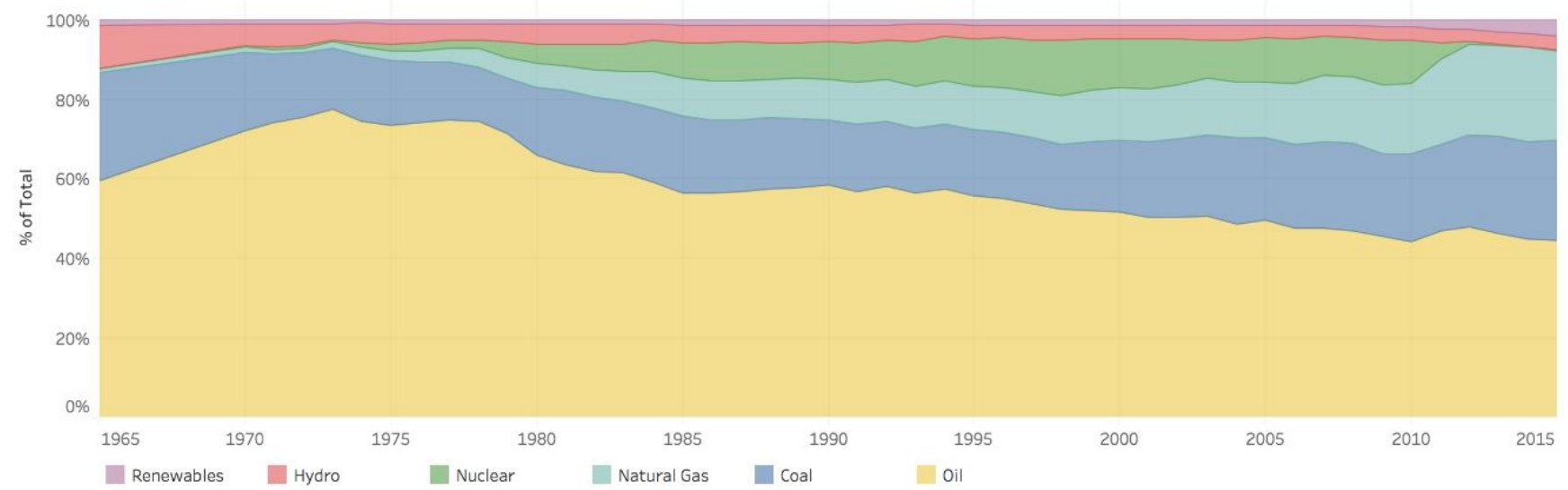

Source: EDMC (2017) - Data excludes energy trade

Figure 5: Gross primary energy supply by fuel $\left(10^{10} \mathrm{kcal}\right)$

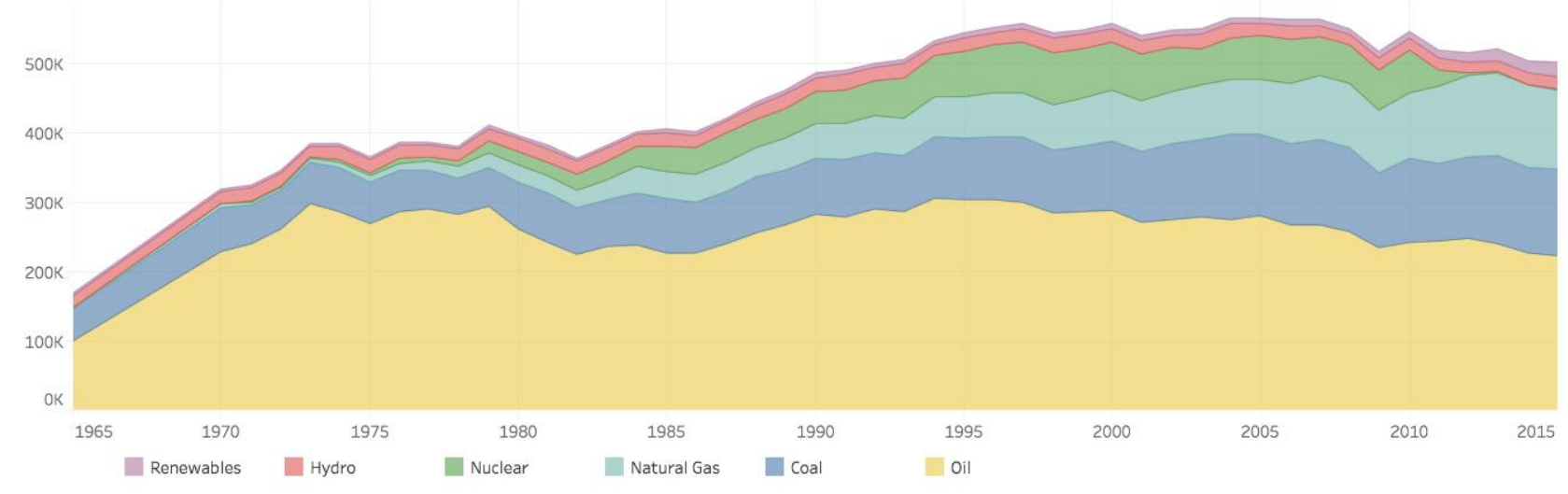

Source: EDMC (2017) - Data excludes energy trade

The share of oil in the energy mix has decreased from its peak of 75.5 per cent in 1973, but in absolute terms the volume of oil imported every day only recently dipped below $4 \mathrm{Mb} / \mathrm{d}$. ${ }^{19}$ Another factor that accounts for the Japanese preoccupation with oil is its role in driving the Japanese postwar economic recovery and its industries. The period of high economic growth in the 1960 s coincided with cheap and abundant crude oil in global oil markets, and from 1965 to 1973 the consumption of crude oil increased from $1.5 \mathrm{Mb} / \mathrm{d}$ to more than $5 \mathrm{Mb} / \mathrm{d}$.

Additionally, the historical experience of the initial classification of Japan as an unfriendly state by OPEC producing countries during the First Oil Crisis, the rise in oil prices, and the shock of the first economic recession in post-war Japan in 1974, have all played a role. These experiences resulted in a strong sense of vulnerability towards supply disruptions and an awareness of the country's

\footnotetext{
${ }^{18}$ Energy mix in 2016: Oil: 41.4\%; Coal: 26.9\%; Natural Gas: 22.5\%; Hydroelectric: 4.1\%; Renewables: 4.2\%. EDMC. ${ }^{19}$ ibid.
} 

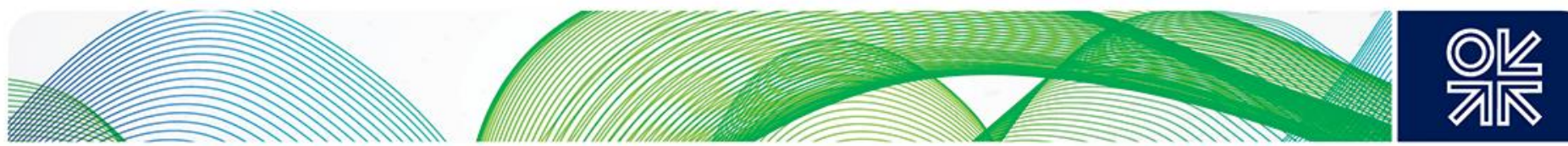

dependence on the Middle East. ${ }^{20}$ Figure 6 below demonstrates changes in crude oil consumption in Japan, phases of economic development, and major supply disruptions, along with forecasted future demand.

Figure 6: Crude oil imports to Japan (Mb/d) - 1965 to 2030

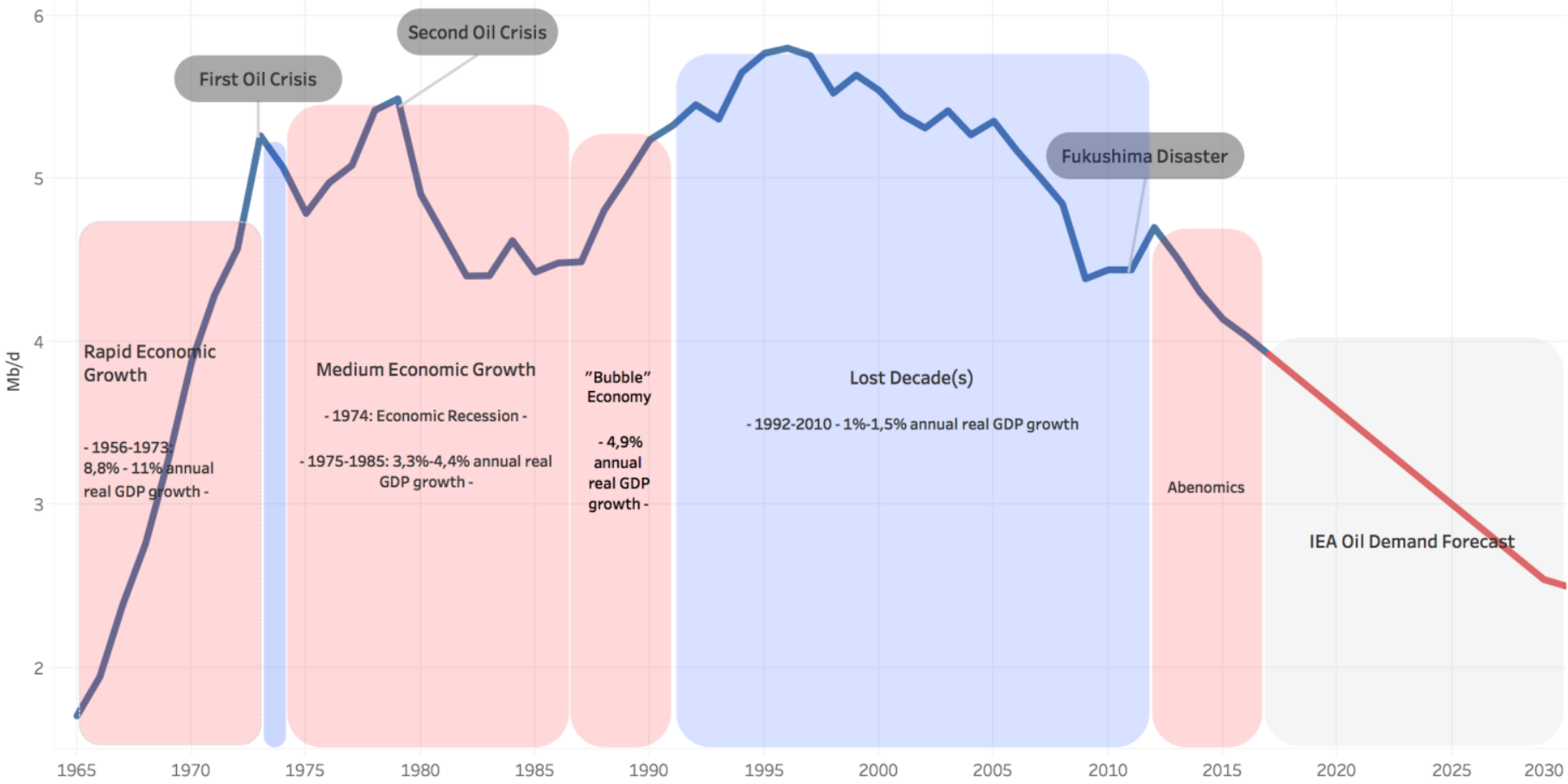

Source: Arranged by author based on Flath (2014), BP (2017) and METI statistics

Following the Second Oil Crisis, oil consumption decreased due to stronger fuel efficiency standards and oil-to-gas and oil-to-nuclear switching, but it grew again in the late 1980s and peaked in 1997. Oil consumption is forecasted to decrease to $2.5 \mathrm{Mb} / \mathrm{d}$ by 2030 , a 50 per cent reduction from 2005 levels, representing a dramatic demand change that may force a re-evaluation of oil-related concerns. ${ }^{21}$

As demonstrated in Figure 7 below, the main sources of oil imports in March 2016 were in the Middle East. In contrast to oil, gas imports are more diversified, and dependency on the Middle East only stood at 23.6 per cent in 2016. ${ }^{22}$

\footnotetext{
${ }^{20}$ Yoshi Tsurumi, 'Japan,' in The Oil Crisis, ed. Raymond Vernon (New York: W.W. Norton \& Company Inc., 1976).

${ }^{21}$ IEA.

${ }^{22}$ METI, 'Enerugi Ni Kan Suru Nenjihoukoku [in Japanese] [Annual Report on Energy].'
} 

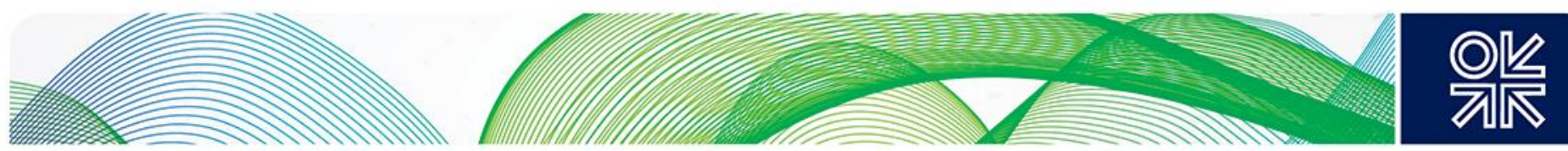

Figure 7: Sources of oil and gas imports in FY 2015 (\% of total gas and \% of total oil)

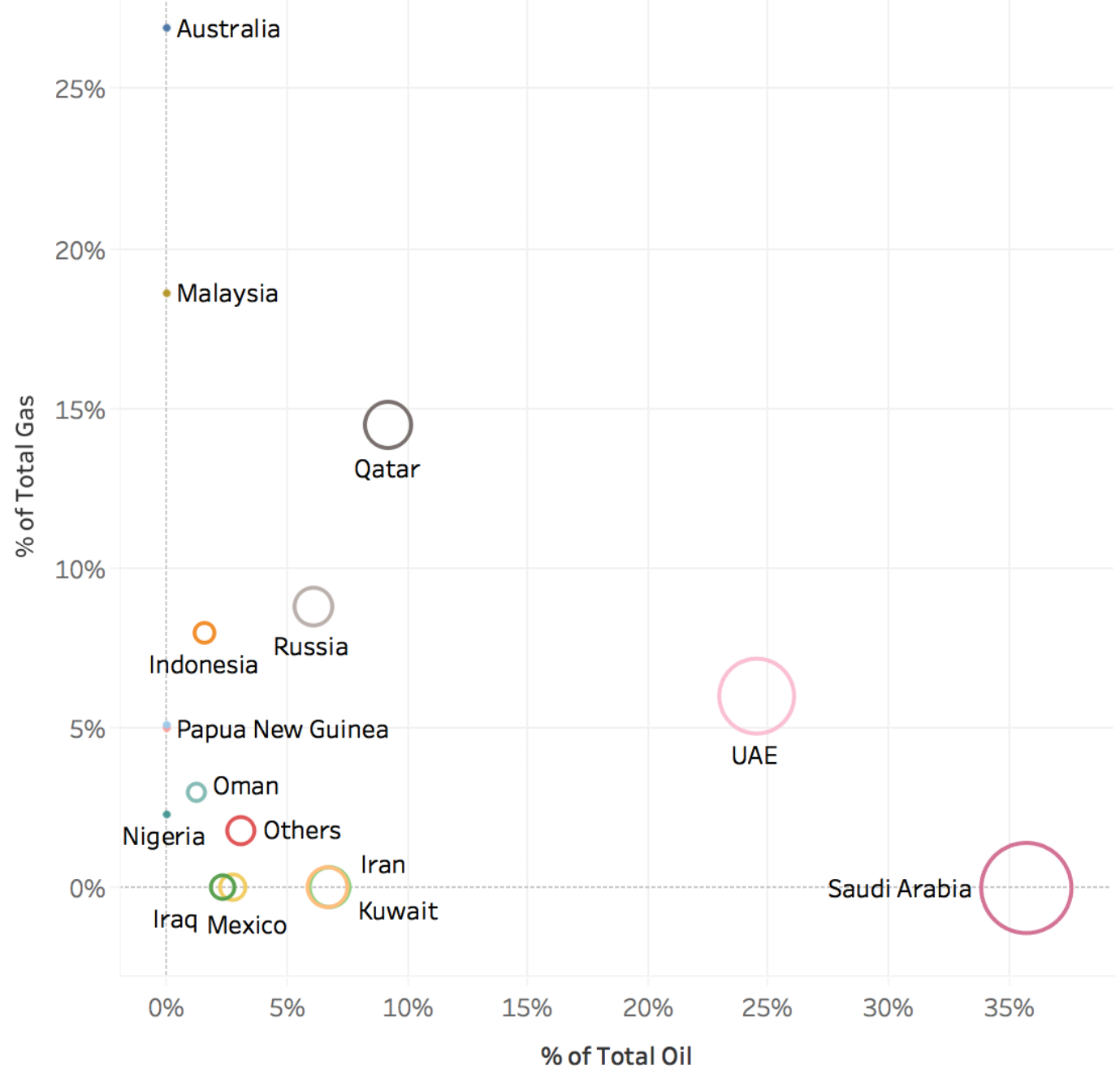

Source: Arranged by author based on METI statistics

Figure 8 below, demonstrates how Middle East dependency decreased after the First Oil Crisis until the late 1980s (from 80 per cent to 70 per cent), as imports from Indonesia and other regions increased. From the 1990s onwards Middle East dependency has crept upwards (available volumes from Indonesia and Mexico decreased as their oil industries went into decline) and stood at 87.2 per cent in $2017 .{ }^{23}$ 

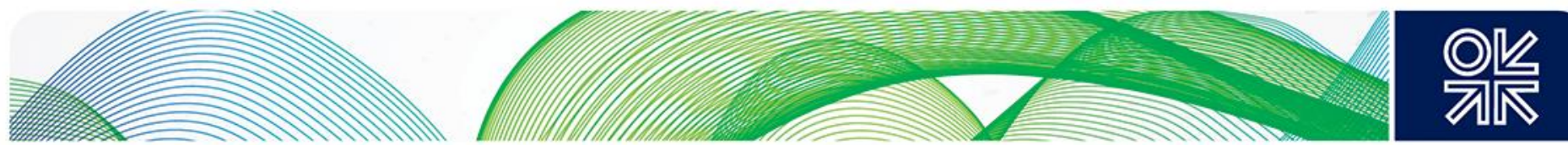

Figure 8: Oil imports and Middle East dependency 1960-2015 (million litres of oil per day and $\%$ from the Middle East)

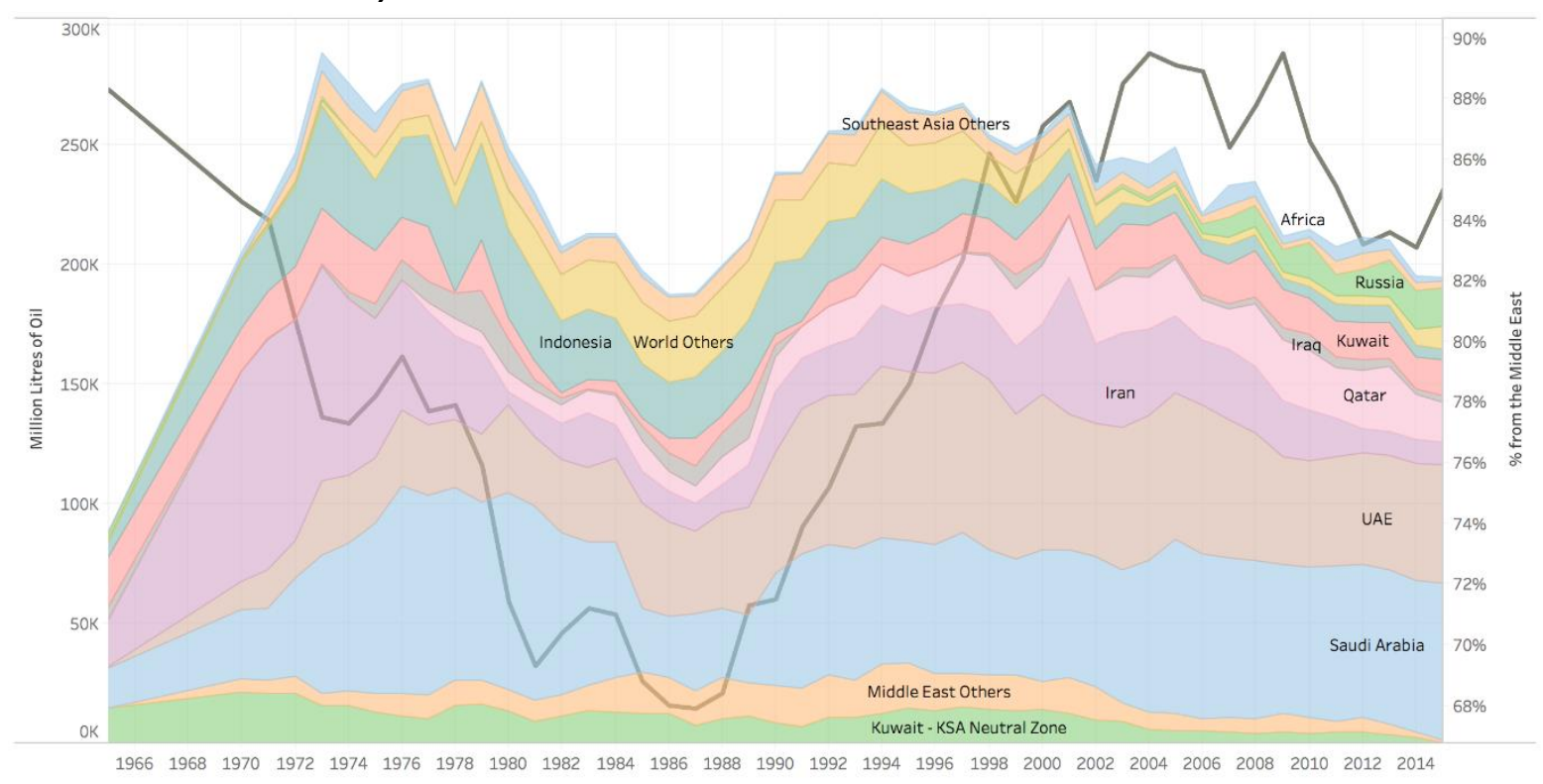

Source: EDMC (2017)

The major change in sources of imports has been the gradually increasing share of KSA, UAE, and Kuwait - at the expense of Iran, Indonesia, and Kuwait. At the time of writing, there are no indicators that this trend will reverse in the short term.

\section{Japanese overseas oil development}

In order to address oil security and import dependency, the Japanese state has supported efforts to increase the ratio of self-developed oil and to diversify imports. However, until the late 1960s, there was relatively limited concern about, or interest in, oil security in Japan. ${ }^{24}$ Post-war oil exploration had restarted in 1955 when JAPEX was established to explore and produce oil domestically, but this yielded limited results - not least given the reality that there are no substantial oil reserves in Japan. ${ }^{25}$

As oil imports increased in the 1960s, voices within Japan started to call for Japanese firms to develop their own overseas oil resources, to reduce the reliance on international oil majors. To address these concerns, the JPDC was established in 1967 to promote the exploration and development of overseas assets, with the aim of reaching a 30 per cent SDR of oil target by 1985 . In response to concerns from Keidanren (Japan Business Federation) and downstream players with capital tie-ups and long-term supply agreements with the majors, the structure of JPDC was confined

\footnotetext{
${ }^{24}$ Before the defeat of World War II a government-owned oil company, Teikoku Oil KK, held concessions in areas that are now in Indonesia, Russia, and China. In the immediate post-war period, almost every single downstream player in Japan established capital tie-ups with US oil companies that ensured the secure supply of oil; policymakers and industry showed limited interest in the upstream sector.

${ }^{25}$ In 1965 JAPEX was permitted to participate in overseas projects. Between 1955 and 1978, 112 exploration wells were drilled onshore at a total cost of JPY 68.5bn, yielding no more than 8,000 barrels per day and failing to have any considerable impact on Japan's reliance on foreign oil. Hughes, Llewelyn. Globalizing Oil: Firms and Oil Market Governance in France, Japan, and the United States (Cambridge: Cambridge University Press, 2014).
} 

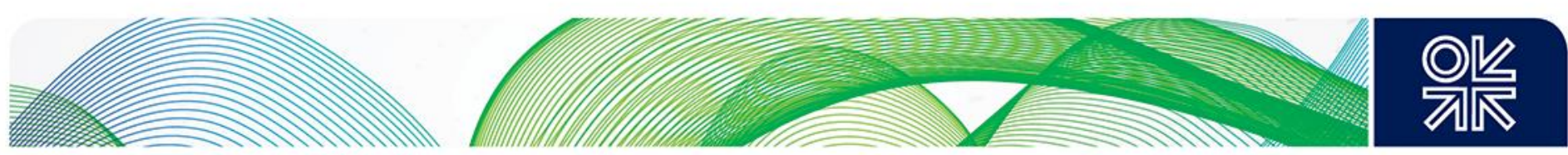

to offering cheap loans and subsidizing the upstream investment projects of other Japanese oil companies, rather than acting as a national oil company. ${ }^{26}$

Several Japanese firms took advantage of JPDC support and participated in upstream projects in countries such as Malaysia, Indonesia, Thailand, Canada, the USA (Alaska), Abu Dhabi, Qatar, and Egypt. JPDC did not discriminate in its investment decisions against firms on the basis of operational experience or investment stakes, and by 1976 it was supporting 60 different projects split between 20 Japanese firms. ${ }^{27}$ It did not act directly as the operator in overseas oil development projects and had no mandate to sell, import, or allocate the crude oil it would potentially produce.

\subsection{Support mechanism for overseas oil develop: Japan National Oil Corporation}

To further strengthen overseas oil development, JPDC was reorganized to form the Japan National Oil Corporation (JNOC) in 1978. JNOC received an enhanced mandate to support upstream activities through equity investments, and accordingly the target for the self-development ratio of oil was revised to $1.5 \mathrm{Mb} / \mathrm{d}$, with a 1990 target achievement date. JNOC could provide up to 70 per cent of required equity for upstream projects during the development stage and guarantee debt up to 60 per cent of loans if projects reached the production stage. Just like JPDC, its predecessor, JNOC was restricted to providing equity, loans, and loan guarantees to the private sector; it could not develop or produce oil under its own name and it did not act as an operator.

Importantly, if no oil was discovered or if it became apparent that the projects were not feasible, then outstanding liabilities to JNOC were waived, and project companies were liquefied. The Japanese government envisioned that by making soft financing and debt insurance available, then private firms would follow and strengthen their presence in the upstream oil sector. In cases where private firms were neither interested nor capable of participating in projects that JNOC (or METI - Ministry of Economy, Trade and Industry) wanted to pursue, JNOC would designate the project as a national project and provide 100 per cent of the initial investment; it would divest down to 50 per cent if oil was discovered, but otherwise take the loss in the case of project failure. ${ }^{28}$

The typical investment arrangement was for JNOC to provide equity and loan guarantees up to 70 per cent of project costs during exploration, and up to 50 per cent of equity and 60 per cent of loan guarantees if projects reached the development stage. (The remaining shares were held by banks, trading companies, and other large corporations). Project companies would then invest a stake in the overseas upstream project together with other foreign oil companies and in most cases as minority shareholders. ${ }^{29}$ Figure 9 below presents a stylized version of the One Project-One Company investment setup.

\footnotetext{
${ }^{26}$ ibid.

${ }^{27}$ Most projects were operated by project-specific companies. The average paid in capital per project was around JPY4.3bn (USD42m) ibid.

${ }_{28}$ Jan-Hein Chrisstoffels, 'Getting to Grips Again with Dependency: Japan's Energy Strategy,' (Hague: Clingendael International Energy Programme CIEP, 2007).

${ }^{29}$ Koike, Mogi, and Albedaiwi.
} 

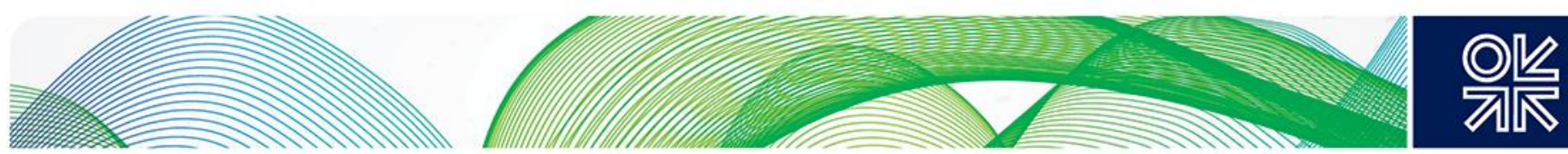

Figure 9: JNOC support in a One Project-One Company consortium

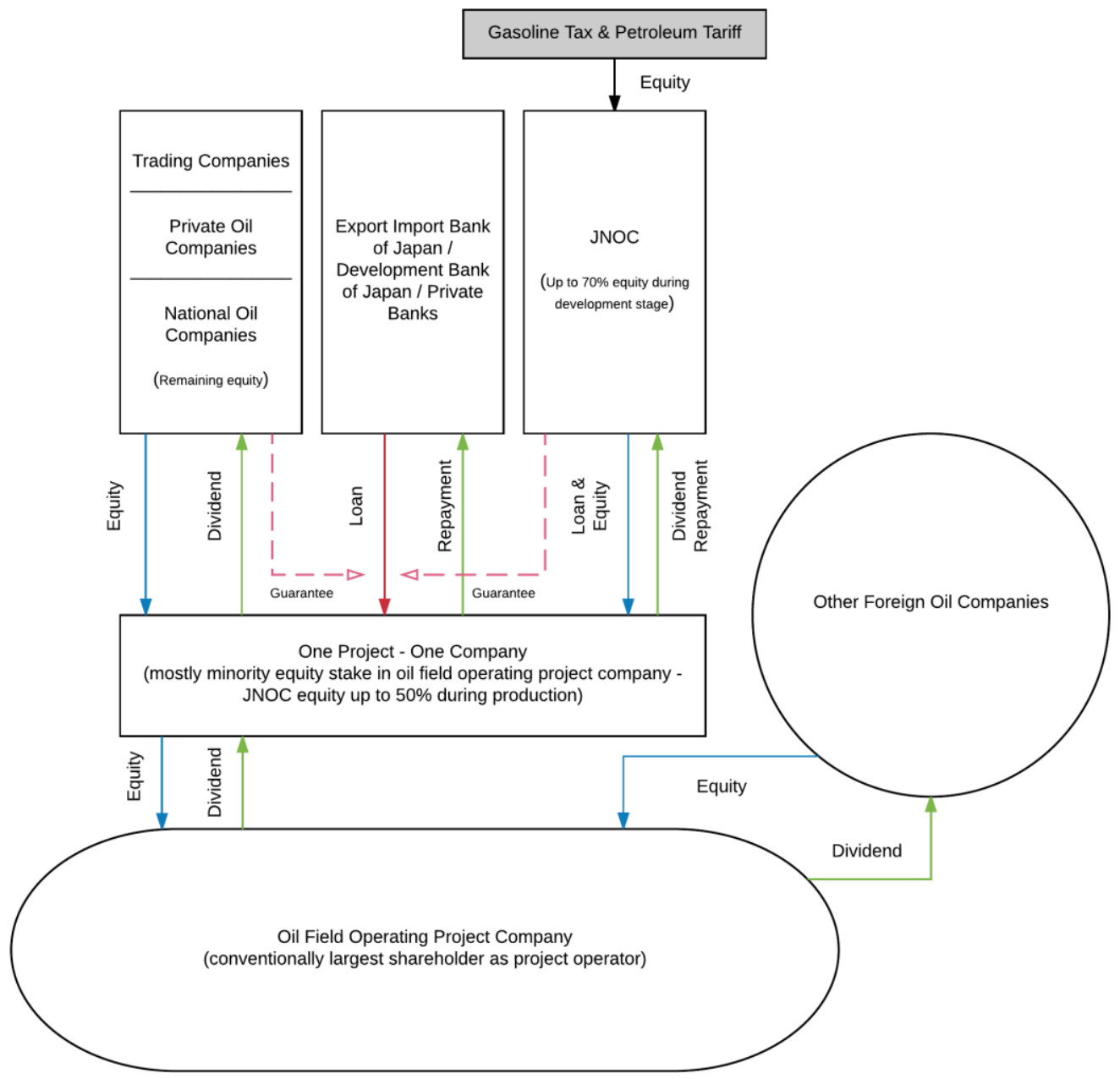

Source: Koike et al. (2008), Zen (2008)

The strengthening of the support mechanism for overseas oil developed through JNOC resulted in the establishment of hundreds of upstream project-specific companies in Japan. By reviewing project data, we see some notable common features of these project companies:

- Predominately minority shares in overseas projects.

- Asia-Pacific centred.

- Low ratio of operatorship.

- Project participation at the exploration stage.

Figure 10 below illustrates the low project concession/PSC share and the internal differences among the three different types of Japanese oil firms. ${ }^{30}$

\footnotetext{
${ }^{30}$ Industry insiders interviewed in Tokyo on 28 July and 29 September 2017 attribute the low share of project concessions or PSCs shares to a combination of difficulties with finding suitable oil development opportunities and a preference for maximizing the number of projects rather than investment shares in individual projects for risk diversification purposes.
} 

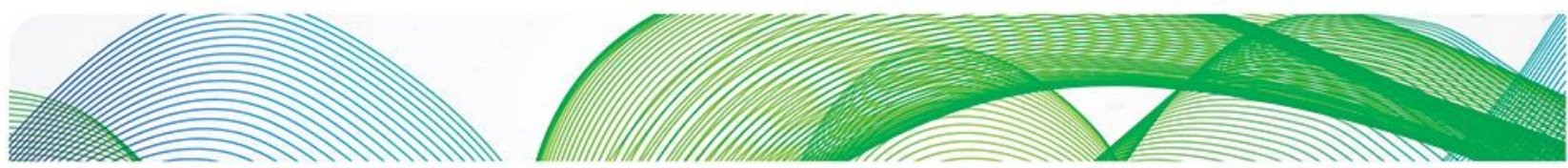

\section{䬧}

Figure 10: Project concession/PCS share (\%) and number of projects (\#)

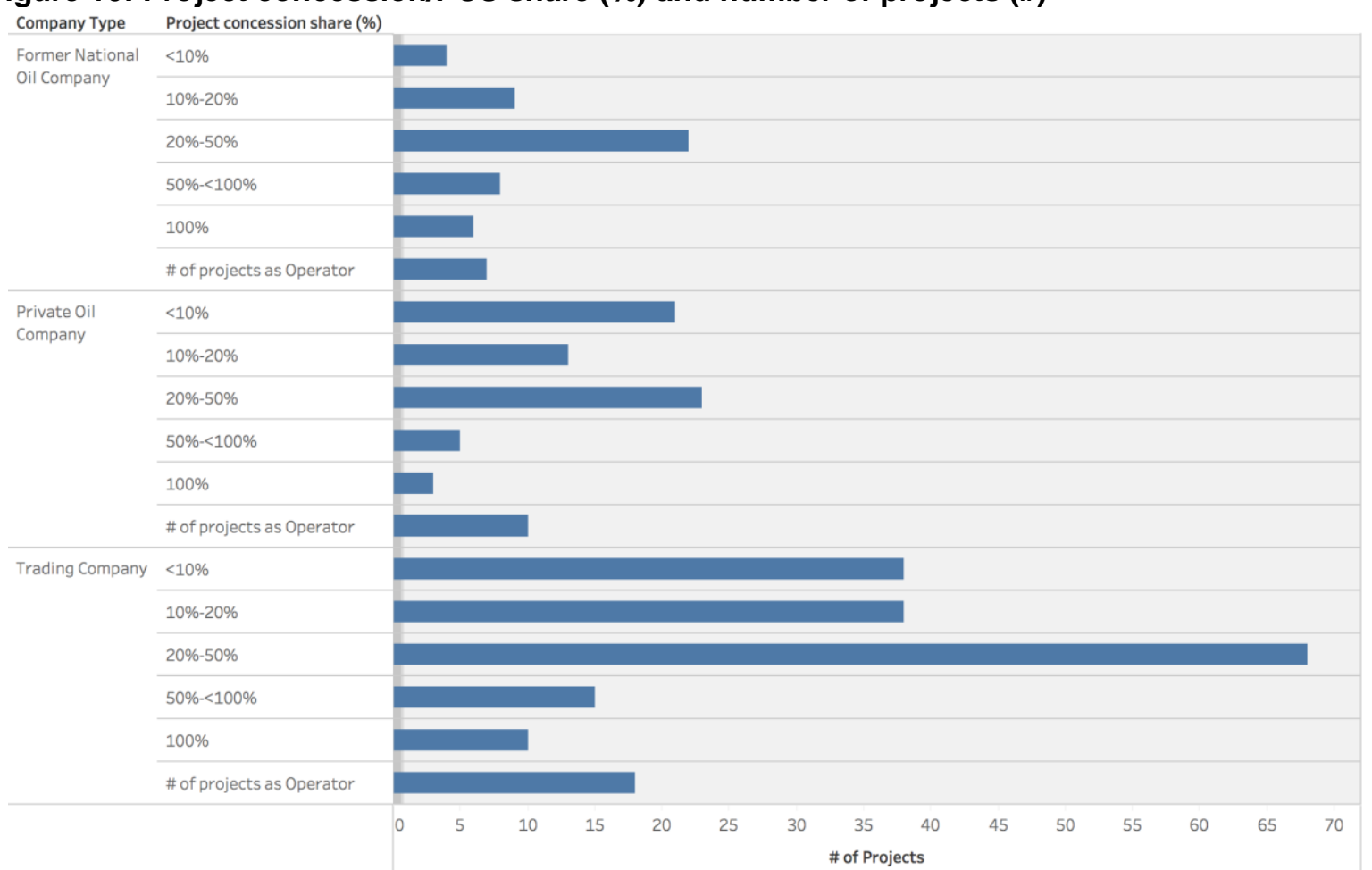

Source: Zen (2008)

In terms of geographical distribution, the majority of projects were located in the Asia-Pacific region, which can be explained by geographical proximity and ease of market access. Figure 11 below illustrates the geographical distribution and share of operatorship.

Figure 11: Number (\#) of upstream oil and gas projects by region and number of operatorship (horizontal black line)

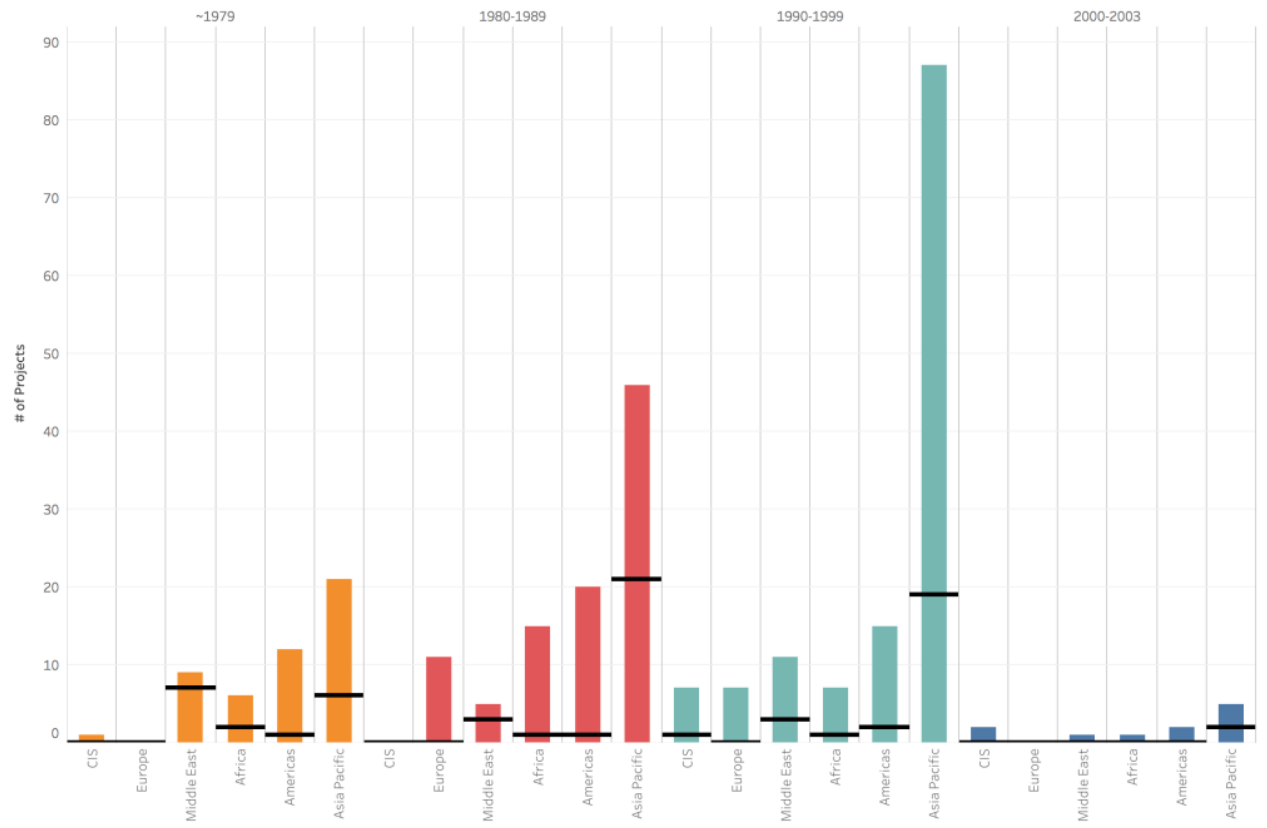

Source: Zen (2008) 

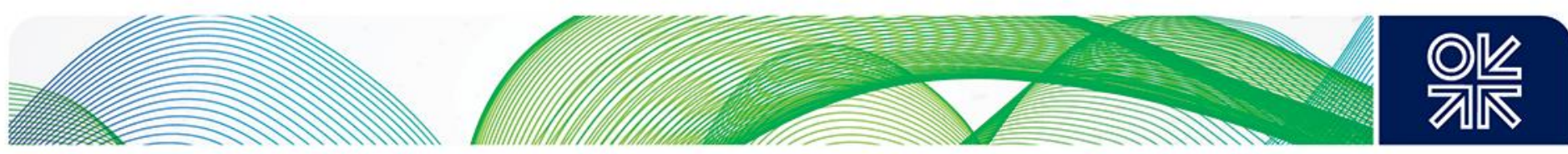

Another feature of JNOC support was a preference for supporting projects during the exploration stage rather than during the development or production stages. Accordingly, 47.8 per cent of all Japanese projects were acquired during the riskiest phase of the project cycle rather than pursuing project acquisition at later stages.

Table 1 below provides an overview of the point of the project development cycle at which different types of firms bought into oil projects.

\section{Table 1: Number of projects by acquisition stage based on company type (1979 to 2005)}

\begin{tabular}{|c|c|c|c|c|c|}
\hline \multirow[b]{2}{*}{ Type of Company } & \multicolumn{4}{|c|}{ Stage of Acquisition } & \multirow[b]{2}{*}{ Tota } \\
\hline & Exploration & Development & Production & Not known & \\
\hline Former National Oil Comp.. & 37 & 2 & 10 & 0 & 49 \\
\hline Private Oil Company & 43 & 9 & 9 & 4 & 65 \\
\hline Trading Company & 1 & 6 & 21 & 27 & 5 \\
\hline
\end{tabular}

Source: Zen (2008)

\subsection{Dismantling of JNOC and birth of JOGMEC}

The institutional design of JPDC and JNOC and the One Project-One Company setup resulted in moral hazard issues, as upside profits in upstream E\&P projects could be captured by private investors, whereas losses were mostly paid for by the Japanese government. Considering government equity, loans, and loan guarantees, the oil development support mechanism effectively offered options to firms interested in oil exploration regardless of operational experience, with a relatively limited financial downside; hundreds of project-specific companies were accordingly established over the lifespan of JNOC. ${ }^{31}$ Not surprisingly JNOC losses grew, and by 2003 the cumulative loss had reached a staggering JPY1, 300bn (USD11.5bn). ${ }^{32}$

Figure 12 below demonstrates the accumulation of losses at JNOC before its dismantling.

Figure 12: JNOC: cumulative equity \& loan contribution and losses (JPY Billion)
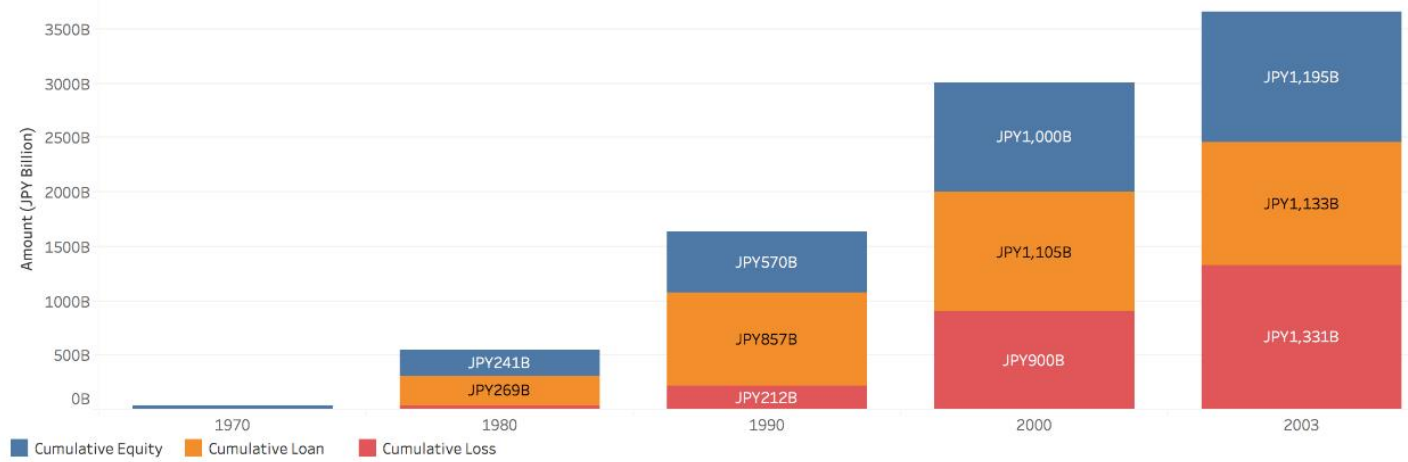

Source: Koike et al. (2008)

JNOC was disbanded after coming under severe criticism from the Liberal Democratic Party (LDP) Koizumi government for wasteful spending, and some observers called JNOC a retirement home for retired MITI bureaucrats. ${ }^{33}$ In 2004, a new organization, JOGMEC, was established as an independent administrative agency, under considerably more stringent governance, to take over the

\footnotetext{
${ }^{31}$ For further discussion in English on the institutional design of JNOC see: Chrisstoffels; Hughes; Koike, Mogi, and Albedaiwi.

${ }^{32}$ Based on the Bank of Japan - JPY/USD exchange rate on the December $5^{\text {th }}, 2017$

${ }^{33}$ Nihon Keizai Shinbun (morning edition, 18th February 2004) cited in Chrisstoffels.
} 

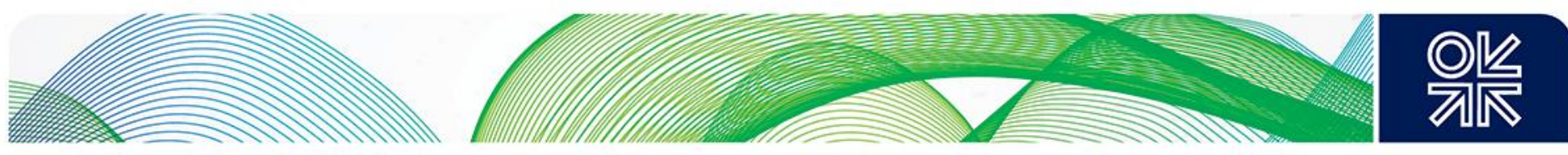

functions of JNOC. The main role of JOGMEC in the case of oil was to provide financial support for oil development, research and development, and oil stockpiling support. ${ }^{34}$

As outlined in Table 2 below, assets previously held by JNOC were split into three groups. The more profitable national project companies - such as JODCO in Abu Dhabi - were merged with INPEX, other project companies were sold (by tender), and JNOC's operations (research and development and human resource development) were taken over by JOGMEC.

\section{Table 2: Breakup of JNOC assets}

\begin{tabular}{|l|l|l|}
\hline $\begin{array}{l}\text { Former National Oil Projects: } \\
\text { INPEX and JODCO }\end{array}$ & Other operational assets & $\begin{array}{l}\text { Assets under exploration and } \\
\text { development, R\&D function, } \\
\text { and human resource } \\
\text { development }\end{array}$ \\
\hline Merged into INPEX & $\begin{array}{l}\text { Sold through a tender with the } \\
\text { lead company (majority } \\
\text { shareholder) retaining a first } \\
\text { bid right OR disbanded. }\end{array}$ & $\begin{array}{l}\text { Transferred from JNOC to } \\
\text { JOGMEC }\end{array}$ \\
\hline
\end{tabular}

The operational model of JOGMEC was also reformed from that of its predecessor; the key differences being that JOGMEC stopped offering loans to upstream projects, equity contributions were capped at 50 per cent of total project size, loan guarantees were also capped at 50 per cent, and JOGMEC lost the mandate to invest directly in so-called national projects.

\subsection{Evaluating Japanese oil policy}

One result of government involvement in the upstream sector in Japan through JNOC was the dependence on government funds for oil development; between 1978 and 1990, JNOC supplied 46 per cent of all upstream investments by Japanese firms. Secondly, the support mechanism allowed for dispersed minority investments by non-operators, which did little to increase operational experience in the Japanese oil industry. ${ }^{35}$ However, as recently as 2015 , the then director general of the Agency for Natural Resources and Energy at METI, Hirohumi Kono, stated that: 'Japanese oil companies can only compete against the International Oil Majors with the support of the government. ${ }^{36}$

Currently, the number of overseas oil projects with which JOGMEC is involved is small when compared to its predecessors. In December 2017, JOGMEC was invested in more than 45 overseas projects involving Japanese players, and out of those the majority involved firms with partial government ownership: 33 per cent of projects involved INPEX, 14 per cent JAPEX, 10 per cent Mitsui, and 43 per cent other firms. ${ }^{37}$ This smaller number of projects having JOGMEC involvement represents a break from previous oil development support mechanisms that supported a diverse group of firms in a very large number of projects.

Japanese oil policy is still directed by METI - in particular the Agency for Natural Resources and Energy (ANRE). A central task of ANRE is to design the Basic Policy for Energy every three years. ${ }^{38}$ In November 2016, the legal mandate of JOGMEC was reformed through a partial revision of the

\footnotetext{
${ }^{34}$ Koike, Mogi, and Albedaiwi.

35 ibid.

${ }^{36}$ Namie Tsujigami and Koji Horinuki, 'Japan in the Gulf - between Intra-Bureaucratic Politics and Inter-Asian Rivalry,' in The Emerging Middle East-East Asia Nexus ed. Yukiko Miyagi and Anoushiravan Ehteshami (London: Routledge, 2015$), 88$.

${ }^{37}$ Author's calculations. Based on a JOGMEC list of major ongoing projects.

JOGMEC, 'Omo Na Shien Purojekuto [in Japanese] [Main Projects under JOGMEC Support],' JOGMEC,

http://www.jogmec.go.jp/oilgas/financial_004.html; 'Renketsu Fuzoku Meisaisho [in Japanese] [Consolidated Supplementary Statements],' (Tokyo: JOGMEC, 2017).

38 Tsujigami and Horinuki, 88.
} 

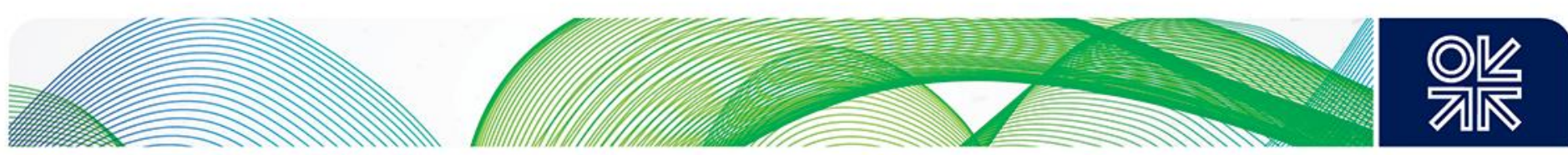

JOGMEC Act, to take advantage of new opportunities brought about by lower oil prices. Before the reform, JOGMEC was only able to support overseas oil development indirectly, by providing equity to Japanese oil companies, but it is now allowed to invest directly in foreign NOCs. In November 2016, the first attempt under the new JOGMEC law was made, to purchase a 10 per cent stake in Rosneft, but this failed and the share was sold to Qatar Petroleum and Glencore instead. ${ }^{39}$ While this first purchase attempt failed, it may have signalled a more direct role for the Japanese state in oil development. It also raises questions about the relationship between the Japanese government and its own private oil companies, and also that between the Japanese oil industry and oil-producing countries in the Middle East and elsewhere.

By measuring the actual self-development ratio of oil against targets, it becomes clear that oil development targets have never been met and that import dependency on the Middle East has not improved. In light of this, it is perhaps valid to question what Japanese oil development policy has achieved and whether it is logical for a resource-scarce country like Japan to attempt to increase its self-development of oil in the first place.

Table 3 below lists explicit targets and results:

Table 3: Self-development ratio of oil targets and results

\begin{tabular}{|l|l|l|l|}
\hline Target set & $\begin{array}{l}\text { Oil Self-development } \\
\text { Target }\end{array}$ & Target date & Results \\
\hline 1965 & $\begin{array}{l}30 \% \text { of total import of } \\
881 \quad 1985 \\
\text { barrels/year million }\end{array}$ & $\begin{array}{l}10.7 \%, \quad 133 \text { million } \\
\text { barrels/year }\end{array}$ \\
\hline 1967 & $30 \%$ of total imports & 1985 & $10.7 \%$ \\
\hline 1978 & $1.5 \mathrm{Mb} / \mathrm{d}$ & 1990 & $0.45 \mathrm{Mb} / \mathrm{d}$ \\
\hline 1983 & $1.2 \mathrm{Mb} / \mathrm{d}$ & 1995 & $0.69 \mathrm{Mb} / \mathrm{d}$ \\
\hline 1993 & $1.2 \mathrm{Mb} / \mathrm{d}$ & $\begin{array}{l}\text { At the beginning of the } \\
21 \text { st century }\end{array}$ & $0.58 \mathrm{Mb} / \mathrm{d}$ \\
\hline 2000 & $\begin{array}{l}\text { Cancellation of } \\
\text { numeric target }\end{array}$ & & \\
\hline 2006 & $\begin{array}{l}40 \% \text { of oil imports of oil and gas } \\
40 \% \text { 2030 } \\
\text { imports }\end{array}$ & 2030 & $27.4 \%$ in April 2016 \\
\hline 2008 & &
\end{tabular}

Source: Arranged by author based on Koike et al, 2008 and METI Statistics

When the recent SDRs of oil and gas are measured together, notable improvements can be observed. This trend is likely to continue as Japanese key LNG projects, such as those in Australia and Africa, start production in upcoming years. ${ }^{40}$ Figure 13 outlines the oil and gas self-development ratio trend from 1973 to 2015 :

\footnotetext{
39 The share of Qatar Oil and Glencore was partially (14.16\%) sold to the Chinese oil conglomerate CEFC in October 2017. Reuters, 'Glencore sale of Rosneft stake earns rivals' respect, bankers' relief,' (2017), https://www.reuters.com/article/usglencore-rosneft/glencore-sale-of-rosneft-stake-earns-rivals-respect-bankers-relief-idUSKCN1BNOHM.

${ }^{40}$ Under current SDR methodology, oil and gas produced and sold into ex-Japan markets are counted when measuring the SDR. Assumptions that oil and gas cargos can be diverted to Japan in the case of an emergency require further scrutiny and an evaluation of individual supply contract between Japanese producers and their customers.
} 

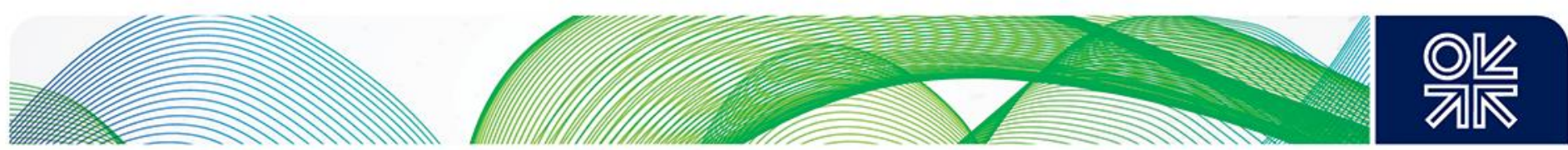

Figure 13: Self-development ratio (\%) of oil and natural gas (1973-2015)

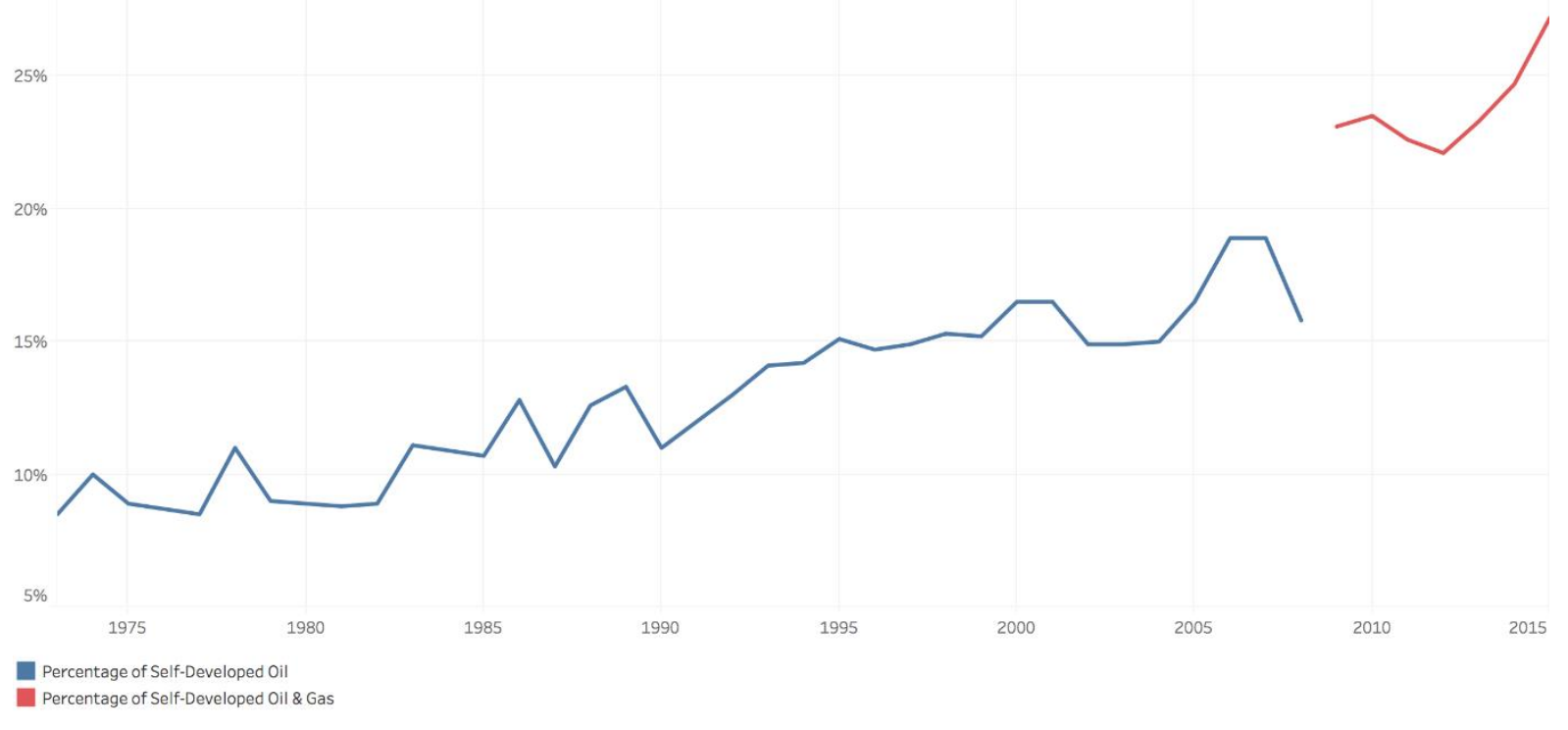

Source: Arranged by author based on METI statistics

\section{Market structure}

Against the backdrop of oil development policy and government involvement in the oil industry, it is important to recognize that the Japanese oil industry is made up of firms with different priorities and capabilities. In addition to government entities like JOGMEC, the major players in the Japanese oil industry fit into three categories: former national oil companies, private oil companies, and trading companies. In 2016 the industry cumulatively produced around $1.467 \mathrm{Mboe} / \mathrm{d}$ of oil and gas (sold both into Japan and to other markets), while domestic refining capacity stood at $3.556 \mathrm{Mb} / \mathrm{d}$. ${ }^{41} \mathrm{We}$ will now provide an overview of the three major types of firms in the Japanese oil industry together with their relationship with the state and future strategy, recent industry consolidation, and the current structure of the oil value chain.

\subsection{Market players}

\subsubsection{Former national oil companies}

INPEX and JAPEX are both former government-owned upstream oil companies; they were partially privatized following the dismantling of JNOC. ${ }^{42}$ The Japanese government still holds an 18.94 per cent golden share in INPEX and a 34 per cent share in JAPEX, through METI. The operational focus of both companies overlaps to a certain extent, but due to legacy issues JAPEX is historically more

\footnotetext{
${ }^{41}$ Source: Author's calculations.

42 INPEX was established in 1966, as a subsidiary of JAPEX. Ownership of INPEX was later transferred to JNOC. In 2003 INPEX took on key JNOC assets such as JODCO in Abu Dhabi and was, in 2006, merged with the remnants of Teikoku Oil through an administrative merger.

JAPEX (Japan Petroleum Exploration KK) was established in 1955 to develop domestic oil fields to increase the oil selfsufficiency rate of Japan. Main basins were in Niigata, Akita prefecture, and more recently in Hokkaido. From the late 1960s and 1970s, the company moved into overseas projects in Canada, Libya, and Indonesia and has been active in tight oil projects in North America and projects in Iraq in recent years.
} 

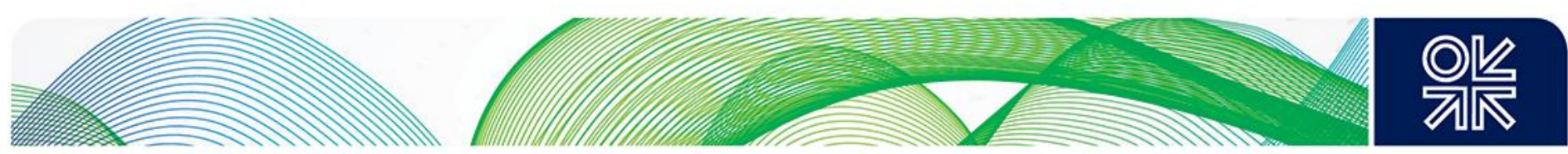

focused domestically, whereas the bulk of INPEX's operations are overseas. In terms of oil and gas production in 2016, INPEX was the larger producer (daily production stood at 514 thousand Barrels of Oil Equivalent per Day (boe/d)), whereas JAPEX's production level was much lower at 73.7 thousand boe/d. Neither company is directly involved in the refining sector but both own a natural gas pipeline network (INPEX: $1400 \mathrm{~km}$ and JAPEX: $800 \mathrm{~km}$ ); these are used to deliver gas to utilities and other industrial customers. ${ }^{43}$

\section{Relationship with the Japanese state}

The presidents, together with a number of senior managers at both companies, are former METI officials, and annual reports and mission statements from both companies reflect this relationship with the Japanese state. Both firms seem to acknowledge the role that they play in securing a stable supply of oil to Japan, thereby supporting Japanese oil policy and the quest for self-developed oil. While neither company is a national oil company in the strictest sense, due to its strategic importance INPEX has been referred to as a so-called core company in Japan by METI; however, according to industry insiders, decision making is commercially driven and direct METI influence in day-to-day operations is limited. ${ }^{44}$

\section{Strategy and future direction}

Both companies aim to increase their production of oil and gas. INPEX aims to reach production levels of $1 \mathrm{Mboe} / \mathrm{d}$ in the near term and JAPEX a more modest 100 thousand boe/d. While oil production remains an important foundation of their business, annual reports, interviews, and recent investments indicate the following future trends:

- An increasingly LNG-driven business model and FLNG projects (INPEX).

- Increased focus on domestic pipeline business, captive customers, and power generation (INPEX/JAPEX).

- A departure from oil project participation at any cost (INPEX/JAPEX).

Additionally, JAPEX is involved in a number of projects that could be defined as national projects. These include an R\&D project on gas extraction from methane hydrates (jointly with JOGMEC), together with the recently completed Soma LNG terminal and ongoing construction of a gas-fired power plant in the Tohoku region - designated as a special economic zone following the devastation of the $3 / 11$ earthquake, tsunami, and nuclear disaster in Fukushima. ${ }^{45}$

\subsubsection{Private oil companies}

Unlike INPEX and JAPEX, the private oil companies in Japan are largely concentrated in the downstream sector. The only notable example of a private oil company with a large upstream presence was the now-defunct Arabian Oil Company (AOC) that held concessions in the Neutral Zone between KSA (until 2000) and Kuwait (until 2002). AOC is in many ways an anomaly in the Japanese oil industry and not representative of the industry. ${ }^{46}$ Today, the major companies are JXTG, Cosmo Oil, Showa Shell, and Idemitsu, in addition to smaller regional players with a focus on the midstream, service stations, and one-refinery companies such as Fuji Oil. ${ }^{47} \mathrm{~A}$ series of mergers (outlined below) has brought down the number of private oil companies in Japan significantly.

\footnotetext{
${ }^{43}$ INPEX, 'Annual Report 2017,' (Tokyo: INPEX Corporation, 2017); JAPEX, 'Corporate Report,' (Tokyo: JAPEX, 2017).

${ }^{44}$ Source: interviews conducted by author in November 2017.

45 The Soma LNG project started operations in November 2017; the first LNG load arrived on 6 December and was supplied by Petronas, a JAPEX partner in Iraq. Joseph Green, 'First LNG Tanker Arrives at the Soma LNG Terminal,' LNG Industry (2017), https://www.Ingindustry.com/liquid-natural-gas/07122017/first-Ing-tanker-arrives-at-the-soma-Ing-terminal/.

${ }^{46}$ Based on interviews with former employees, AOC was perceived as a maverick company within Japanese bureaucratic circles and received limited government support in Japan, partially due to the entrepreneurial background of its founder. ${ }^{47}$ Despite its name, Showa Shell Sekiyu is only a Shell licence holder. Idemitsu purchased a $31.25 \%$ stake in Showa Shell in 2016 from Shell that currently holds less than $4 \%$ of Showa Shell's stocks. Idemitsu and Showa Shell are undergoing merger talks and currently cooperate under a business alliance that includes joint purchases of crude oil.
} 

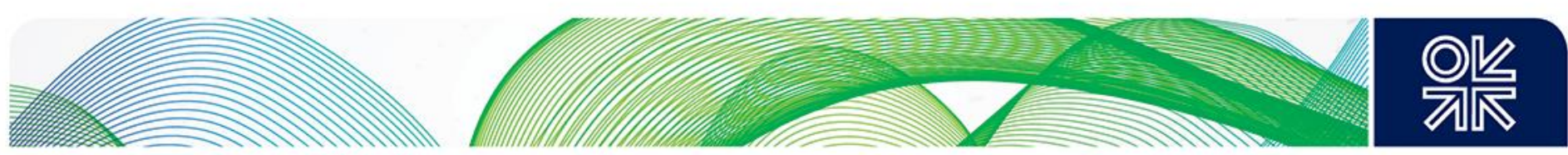

In terms of refining capacity in 2016, JXTG is a dominant player in Japan with $1.93 \mathrm{Mb} / \mathrm{d}$, followed by Idemitsu (500 thousand b/d), Cosmo Oil (400 thousand b/d), and Showa Shell (445 thousand b/d). Among the private oil companies, JXTG is also the largest producer of oil and gas at 120 thousand $\mathrm{b} / \mathrm{d}$, followed by Idemitsu ( 43 thousand $\mathrm{b} / \mathrm{d}$ ), and Cosmo Oil (41 thousand b/d). ${ }^{48}$

\section{Relationship with the Japanese state}

In contrast to INPEX and JAPEX, senior managers and board members at the private oil companies are almost exclusively drawn from the private sector and there are also examples of non-Japanese directors at firms such as Showa Shell (14.96 per cent of shares held by Saudi Aramco) and Cosmo Oil (which has capital ties with various entities in Abu Dhabi). ${ }^{49}$ Historically, and especially in the 1970s and 1980s, the relationship between METI (prior to 2001, with its predecessor, MITI) and the private oil companies has also been turbulent, due to discord on industrial policy, capacity licensing, and other forms of interference. ${ }^{50}$

Attempts to merge private oil companies with former national oil companies have also been made by METI, in order to create a so-called Japanese major (j. wasei meja). These attempts have, however, been unsuccessful. The most notable recent attempt was an administrative merger between INPEX and JX (predecessor to JXTG) in the early 2000s, but this failed.

\section{Strategy and future direction}

Due to their focus on the downstream sector, the private oil companies do not publish explicit production targets for oil and gas. Instead, this group of companies is faced with decreasing demand for refined products in Japan and they have therefore diversified into other businesses in recent years. Companies like JXTG already have large mining and metals divisions, and Cosmo Oil has established a wind generation business. By reviewing annual reports, the following trends become apparent:

- Decreased focus on refining business in Japan; optimization of capacity and strategic alliances with other downstream players.

- Increased focus on new business units in Japan.

- Increased focus on high-growth markets where Japanese firms face relatively low entry barriers (such as Vietnam, Thailand) and focus on mature markets (such as Taiwan and Australia). ${ }^{51}$

The private oil companies are profit-driven, and their competitive advantage lies in refining, petrochemicals, mining, and marketing rather than in oil exploration. Therefore, they are naturally less concerned with oil and gas self-development targets than their peers - INPEX and JAPEX.

\subsubsection{Trading companies}

Major trading companies like Mitsui Bussan, Mitsubishi Shoji, Sumitomo Shoji, and Itochu Shoji entered the oil business in the early 1970s. This was partly in response to government pleas to facilitate the procurement of oil for downstream players and utilities in Japan following the First Oil Crisis. These oil purchases, at a premium, by Japanese trading companies became infamous as they

\footnotetext{
${ }^{48}$ Showa Shell, 'Corporate Report 2017,' (Tokyo: Showa Shell Sekiyu K.K., 2017); Cosmo Oil, 'Cosmo Energy Holdings Cosmo Report 2017,' (Tokyo: Cosmo Energy Holdings, 2017); JXTG, 'JXTG Report Sogou Report 2017 [in Japanese] [JXTG Consolidated Report 2017],' (Tokyo: JXTG, 2017); Cosmo Oil; FOC, 'Annual Report 2017,' (Tokyo: Fuji Oil Company, Ltd., 2017); Idemitsu, 'Annual Report,' (Tokyo: Idemitsu Kosan Co. Ltd., 2017).

${ }^{49}$ The International Petroleum Investment Company (IPIC) of Abu Dhabi purchased a 20\% stake in Cosmo Oil in 2009 and historically the management of Cosmo Oil has had a strong relationship with Abu Dhabi.

${ }^{50}$ Among private oil companies, Idemitsu plays a special role. The company traces its history back to pre-war downstream operations in Japanese-occupied China, Korea, and Taiwan; its founder, Sazou Idemitsu, was traditionally hostile towards Western Oil Majors and government interference. Accordingly, the company has a long history of conflict with the Japanese state - whether with METI or MOFA - over issues such as its purchases of oil from the Soviet Union in the 1950s and from Iran after the nationalization of its oil industry in the 1950s.

${ }^{51}$ Idemitsu recently completed a refining and petrochemical complex in Vietnam and established Idemitsu Q8 Petroleum LCC together with Kuwait Petroleum, to facilitate downstream sales in Vietnam.
} 

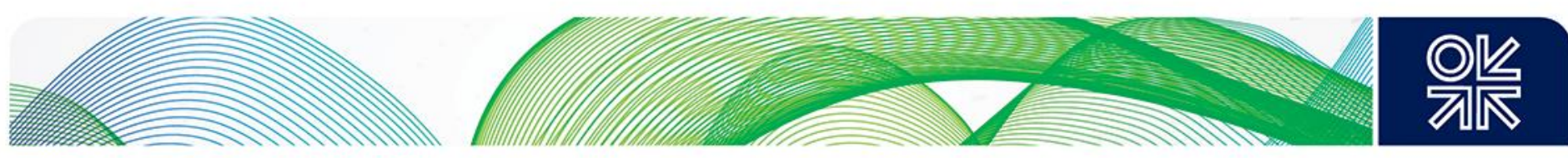

drove up prices in the emerging Rotterdam spot market in the immediate aftermath of the First Oil Crisis. ${ }^{52}$ Since then, trading companies have moved from what was predominantly a procurement function, to oil and gas exploration and development, and project acquisitions.

Among the trading companies, Mitsui produces the largest amount of oil and gas at 258 thousand boe/d, making it the second-largest producer in Japan. Mitsui is followed by Mitsubishi (188 thousand boe/d), Itochu (36 thousand boe/d), Marubeni (28 thousand boe/d), and Sojitz (13.5 thousand boe/d). ${ }^{53}$ The trading companies themselves are generally not directly involved in the downstream sector in Japan, but there are several cases of group company involvement for strategic reasons, in addition to participation in various overseas projects, such as Ras Laffan in Qatar. Compared to other Japanese oil companies, the trading companies show a preference for opportunistic brownfield project acquisitions - such as the acquisition from Santos in Australia made by Mitsui and Co. Ltd. in $2016 .{ }^{54}$

\section{Relationship with the Japanese state}

The relationship between trading companies and the Japanese state has historically been symbiotic. Trading companies have played procurement roles for Japanese industries, performed marketing functions for Japanese products, and provided information on overseas developments through their wide networks (these often exceeded those of the state). To this date, the procurement role of trading companies is still valuable for Japanese industries, and trading companies often play the role of dealmakers on behalf of other companies. In the oil and gas sector, trading companies are mostly involved in commercially driven overseas upstream projects that are perceived favourably by the Japanese state.

\section{Strategy and future direction}

Trading companies are faced with decreasing demand for LNG in Japan, while the emergence of utility-owned purchasing companies such as JERA decreases opportunities to act as middlemen in crude oil and LNG procurement at home. ${ }^{55}$ Therefore, while they will continue to be active in oil and gas, the following trends can be expected:

- Gradual realignment towards ex-Japan off-takers for oil and gas.

- Opportunistic participation in brownfield upstream projects.

- Continued focus on LNG project participation in the Middle East and in countries such as Mozambique.

\subsection{Consolidation in the industry}

Except for the trading companies, the market players discussed above are mostly the result of recent mergers and consolidation in the Japanese oil industry. ${ }^{56} \mathrm{~A}$ defining feature of the Japanese oil industry is a historically fragmented industry that is split between the upstream and downstream

\footnotetext{
52 Chrisstoffels.

${ }^{53}$ Sumitomo production levels are not publicly available but estimated at 10-15 thousand boe/d. Production data includes subsidiaries and majority-owned group companies. Mitsui, '2018 Nen 3 Gatsuki Dainisihanki Kessai Setsumei Shiryo [in Japanese] [Financial Report Documents for the 2nd Half of Fiscal Year Ending in March 2018],' (Tokyo, 2017); Sumitomo (Petro Summit), 'Petro Summit E\&P Corporation,' http://www.psep.tokyo.jp/company/history/; Mitsubishi, '2017 Nendo Dainihanki Ir Shiryo [in Japanese] [2017 H2 Investor Relations Documents],' (Tokyo: Mitsubishi Corporation, 2017); Sojitz. 'Inquiry on Sojitz Daily Oil and Gas Production' by Loftur Thorarinsson, 13 December 2017; Marubeni, 'Marubeni Kabushikigaisha Sougou Hokokusho 2017 [in Japanese] [Marubeni KK Consolidated Report 2017],' (Tokyo: Marubeni Corporation, 2017); Itochu, 'Annual Report 2017,' (Tokyo: Itochu Corporation, 2017).

${ }^{54}$ Mitsui, 'Completion of the Acquisition of Santos' Interest in an Offshore Gas and Condensate Field in Australia,' Mitsui, https://www.mitsui.com/jp/en/release/2016/1218623_8910.html.

55 JERA is an LNG purchasing alliance between Tokyo Electric and Chubu Electric.

56 Trading companies in their current form were established in the immediate post-war period. However, most of the firms can trace their history back at least to the 19th century.
} 

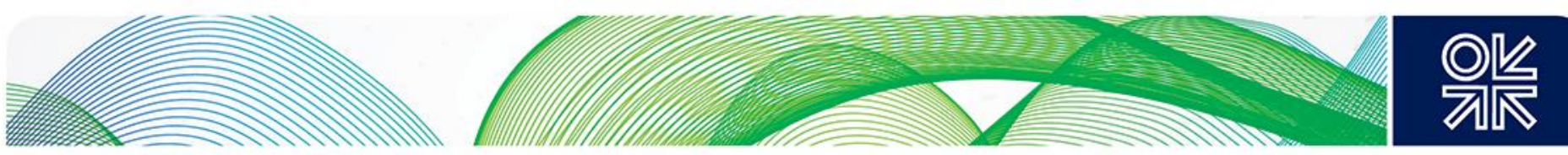

sectors. ${ }^{57}$ While the upstream-downstream split is still prevalent, considerable efforts have been made both by industry and government to consolidate and rationalize the Japanese oil industry.

\subsubsection{Consolidation in the downstream sector}

The key drivers behind consolidation in the downstream sector were: market liberalization in the 1980s and 1990s, divestments by western oil majors in their Japanese downstream partners, the expiry of long-term supply agreements, and the impact of chronic refining overcapacity.

Figure 14 shows the consolidation from 17 to four major corporate downstream groups. ${ }^{58}$

Overcapacity in Japanese oil refineries has also improved, and capacity utilization rates have increased from a low point of 66 per cent (1980) to 86 per cent (2016). Smaller, less efficient, refineries were decommissioned, often in conjunction with government support for the affected downstream players. Considering a future decrease in demand for refined petroleum products, the industry is expected to continue on this trajectory.

\section{Figure 14: Downstream industry consolidation}

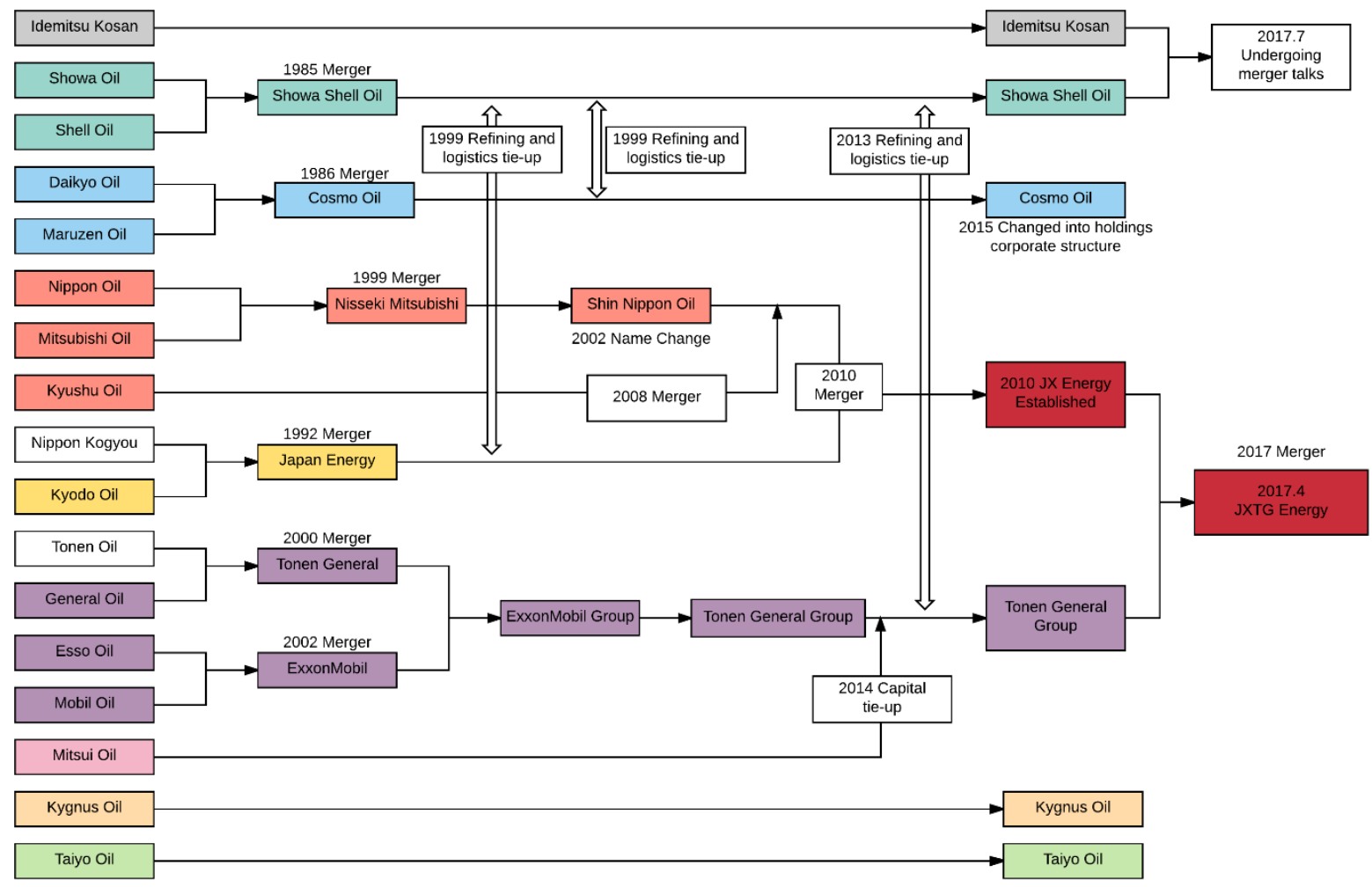

Source: Arranged by author based on METI

Figure 15 shows the trend of decreasing refining capacity and increased utilization rates:

\footnotetext{
${ }^{57}$ Fundamentally, the reason behind industry fragmentation is a combination of: industrial policy that favoured such fragmentation in the downstream sector to encourage competition, an ambivalence towards horizontal integration, a policy of participating in the maximum number of upstream projects with a large number of Japanese oil and non-oil companies, and lastly resistance from downstream players who had capital ties with the majors to any sort of horizontal or vertical integration. Takeo Kikkawa, Sekiyu Sangyo No Shinjitsu [The Truth About the Oil Industry] (Tokyo: Sekiyu Tsushin, 2015).

${ }^{58}$ The four groups today are Idemitsu Kosan, Showa Shell Oil, JXTG, and Cosmo Oil. Kygnus Oil (Shareholders - Mitsubishi Oil: $80 \%$, Cosmo Oil: $20 \%$ ) and Taiyo Oil are small regional retail firms.
} 

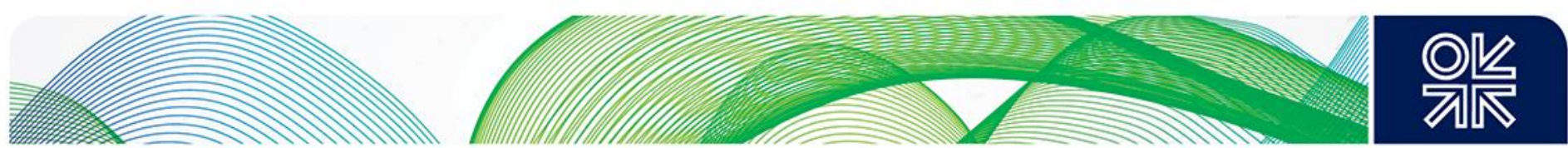

Figure 15: Downstream refining capacity (thousand b/d) and industry refining utilization rate (\%)

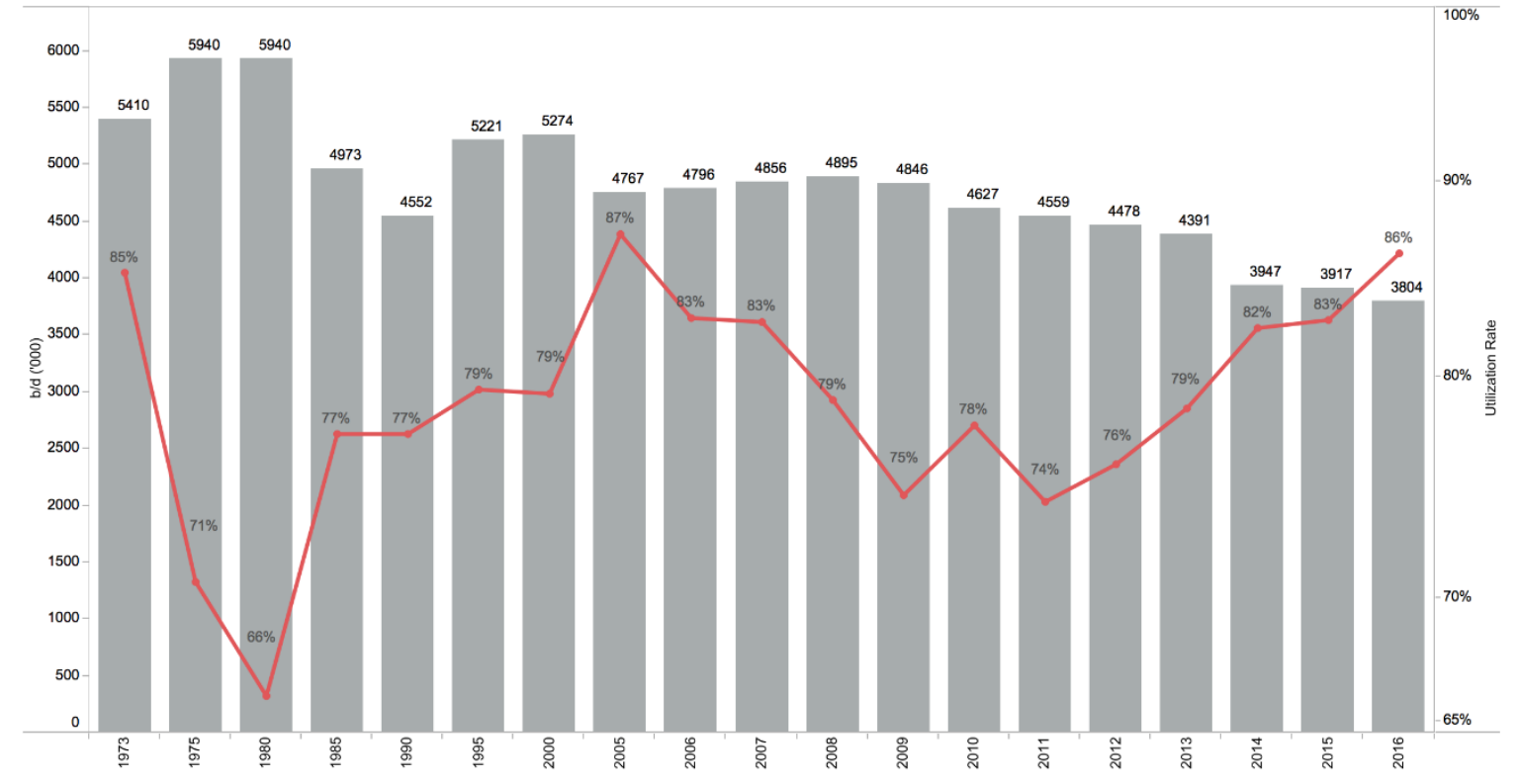

Source: Petroleum Association of Japan (2017)

\subsubsection{Consolidation in the upstream sector}

In comparison to the downstream sector, the market structure and main players in the upstream sector have been relatively stable in recent years. Most of the One Project-One Company consortia discussed in Section 3 were either disbanded or consolidated with other oil companies in the 2000s. Figure 16 provides an overview of how the upstream sector has evolved in recent years: 

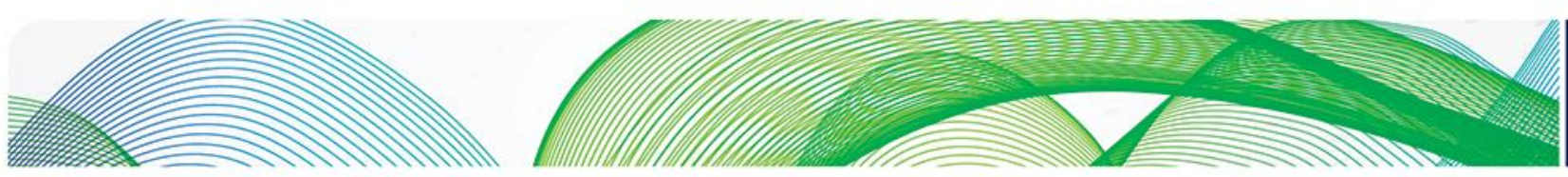

Figure 16: Upstream industry consolidation

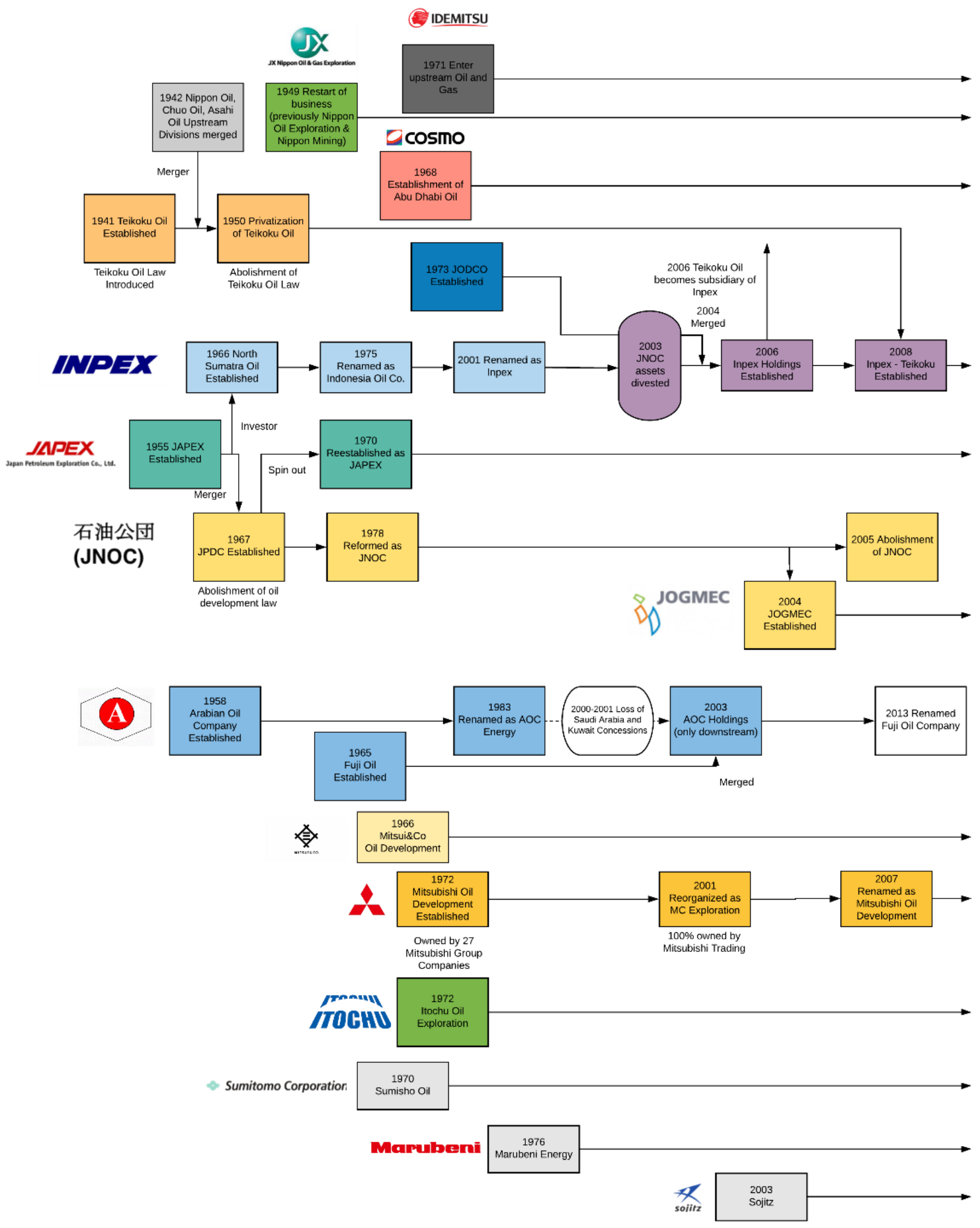

Source: Arranged by author based on METI reports 

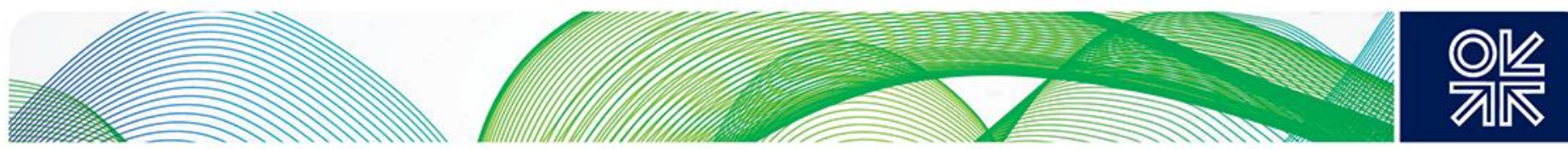

\subsection{Upstream-downstream split}

Despite notable industry consolidation, the upstream-downstream split is a persistent feature of the industry. The former national oil companies and trading companies dominate the upstream sector but have no presence in the downstream sector. Conversely, apart from JXTG and, to a lesser extent, Cosmo Oil and Idemitsu, the upstream operations of private oil companies are limited.

Figure 17 below provides an overview of upstream oil and gas production based on the three categories of Japanese oil companies (former national oil companies, private oil companies, and trading companies) for April 2017:

\section{Figure 17: Oil and gas production by company type (boe/d)}

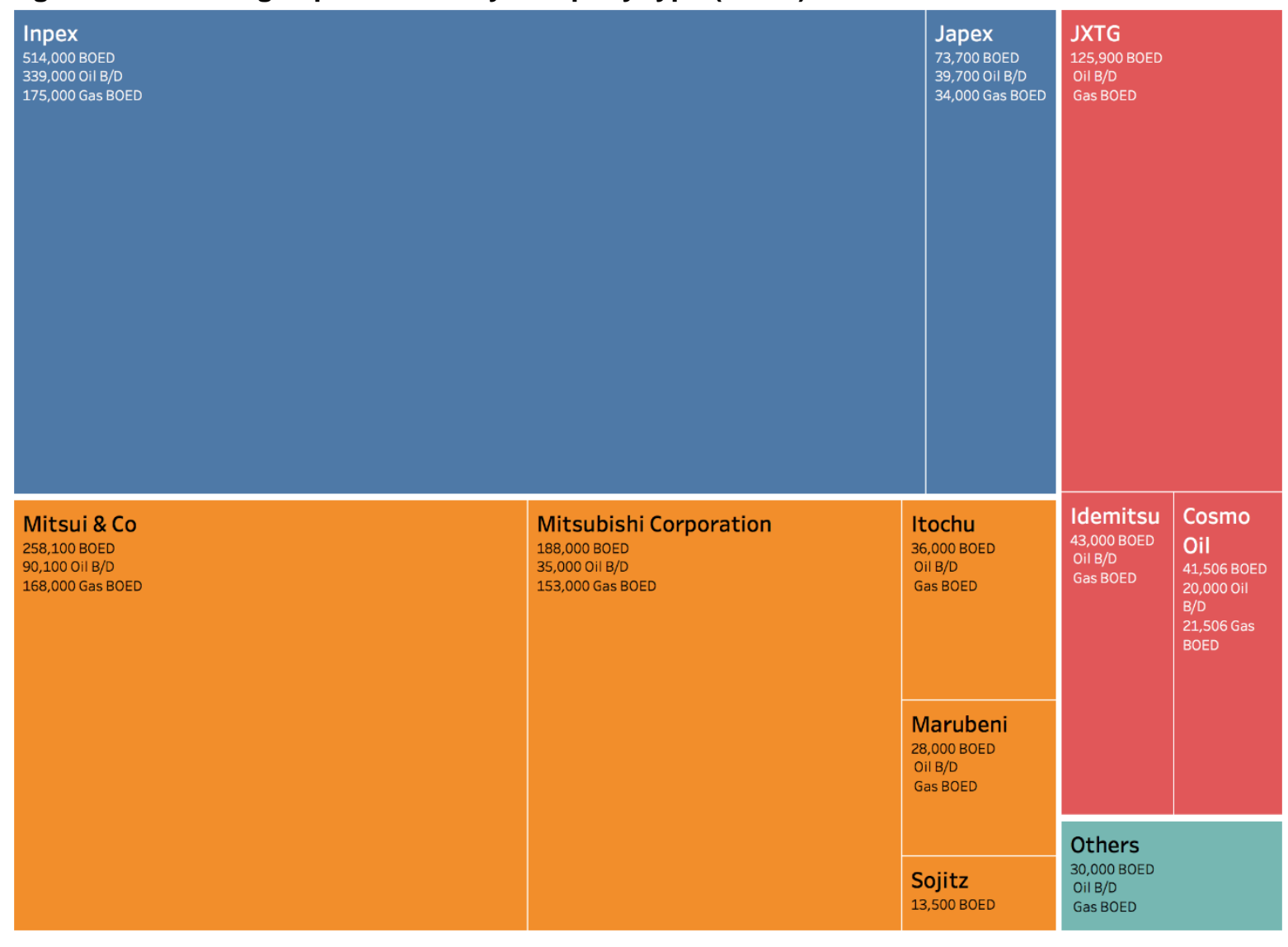

Eormer National Oil Company $\quad$ Private Oil Company

Trading Company

Others

Source: Annual Reports \& Investor Relations.

In the downstream sector, JXTG has reached a dominant position with 50 per cent of refining capacity. Further consolidation can be expected considering the strategic alliance between Showa Shell and Idemitsu.

Figure 18 below illustrates refining capacity in April 2017: 

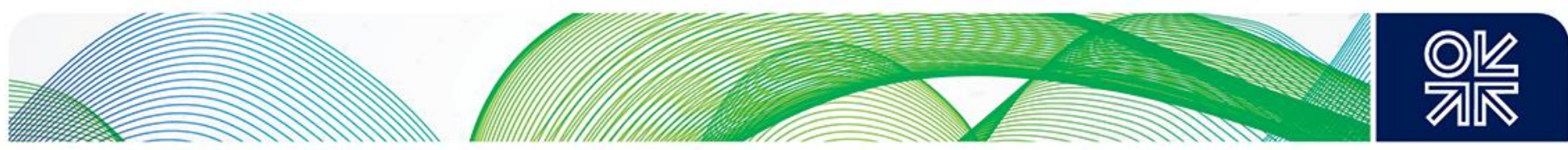

Figure 18: Oil refining capacity by company (b/d)

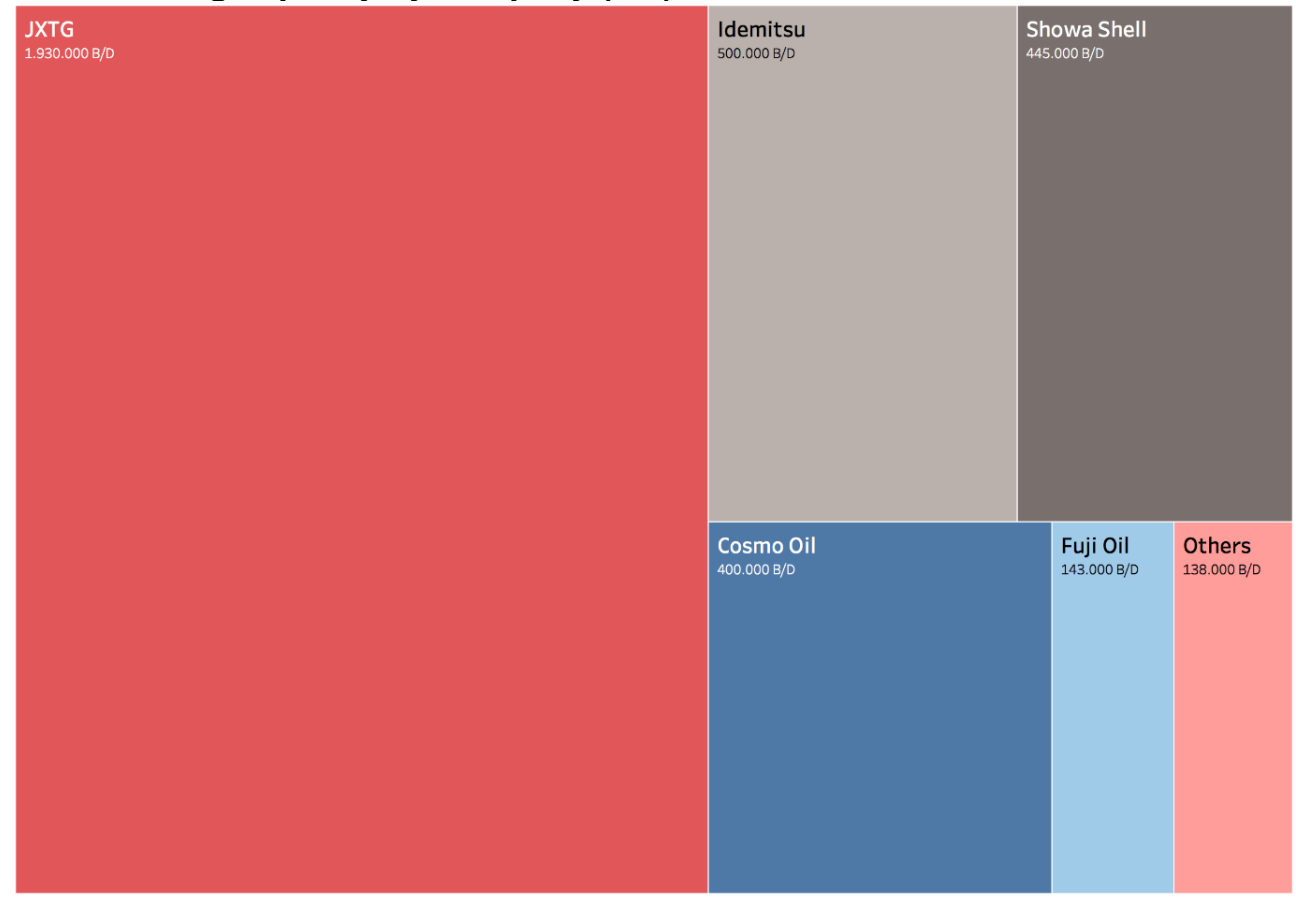

Source: Annual Reports

Consolidation in the upstream and downstream sectors has significantly decreased the number of market players. The industry is still fragmented in comparison to countries with large national oil companies (NOC) or international oil companies (IOC), but the current structure represents a considerable change from the Japanese oil industry in the 1980s where hundreds of companies existed.

Figure 19 below outlines the main firms in the oil industry value chain today:

\section{Figure 19: Oil industry structure}

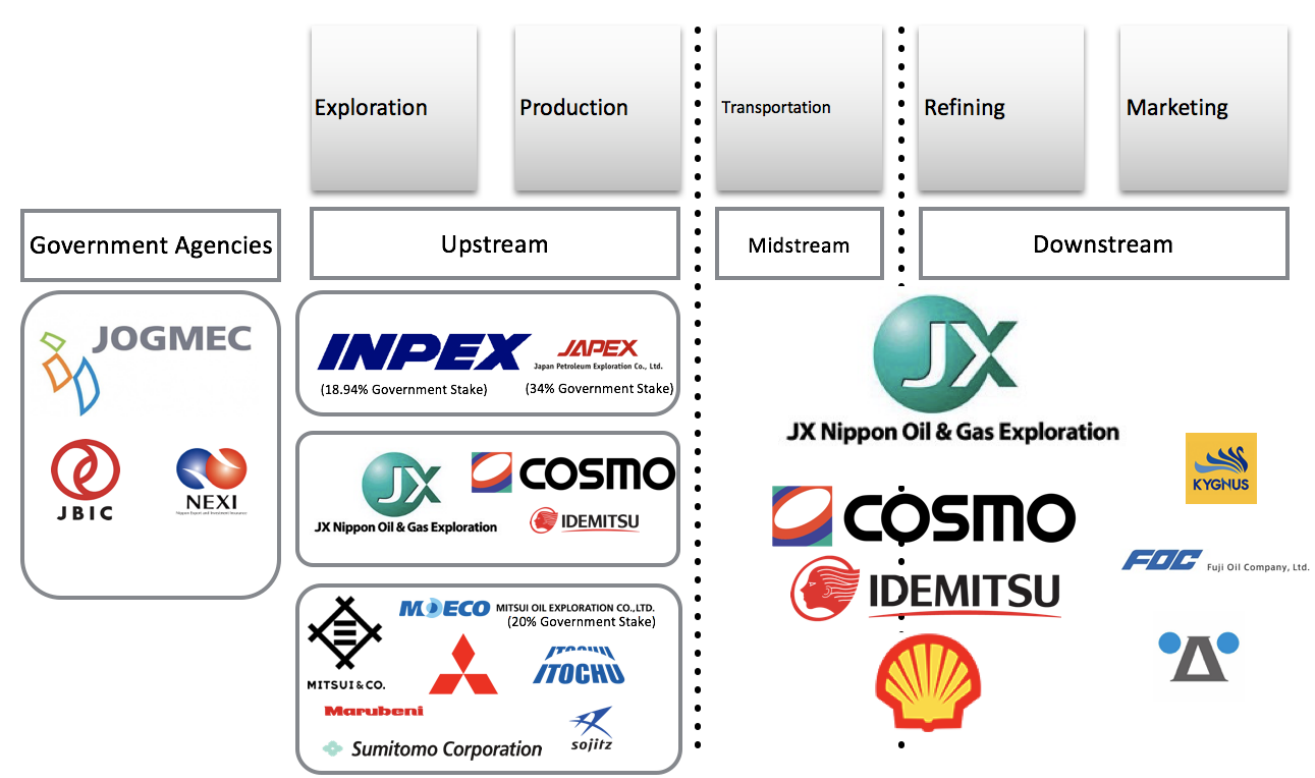

Source: Company and institutional websites 

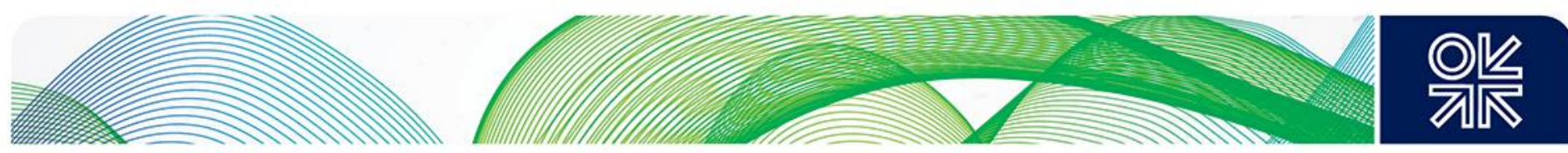

\section{Resource diplomacy towards the Middle East}

Resource diplomacy has been influenced by two competing strategic factors: Japan's energy dependency on the Middle East and the USA-Japan security relationship. Additionally, different domestic views by METI and MOFA on how to conduct overseas economic policy have, at times, impacted decision making. This dual dependency has caught up Japan between conflicting US and Middle Eastern interests, and for this reason, Japan has attempted to balance its relations while avoiding alienating either the USA or Middle Eastern countries. Subsequently, Japan's default policy response in conflicts such as the Arab-Israeli conflict, KSA-Iran conflicts, and more recently in the Qatar diplomatic crisis, has been to attempt to maintain political neutrality. Such a position of neutrality has, however, not always been the case, and since the First Oil Crisis, Japanese resource diplomacy towards the Middle East has gone through three distinct phases. ${ }^{59}$

\subsection{First phase of resource diplomacy towards the Middle East}

The legacy of the First Oil Crisis remains strong in Japanese policy circles, as it represented the first time that Japan became involved in regional affairs in the Middle East and it resulted in a foreign policy shift from inactive neutralism to active neutralism. ${ }^{60}$ Before the First Oil Crisis, Japan imported most of its oil from the Middle East through Western oil majors operating in the region, and to a lesser extent from private oil companies such as Idemitsu and the now-defunct Arabian Oil Company. Policymakers woke up to the need to deepen the relationship with oil producers following the establishment of OPEC. However, when Japan was designated as an unfriendly state by OPEC members in 1973, government-to-government relations in the region were found to be limited and diplomatic channels underdeveloped. ${ }^{61}$ The Oil Crisis, therefore, caught policymakers off guard, caused panic in Tokyo, and led to a rapid shift in the relationship with the Middle East.

Figure 20 illustrates how the share of NOCs as suppliers of crude oil to Japan rapidly increased at the expense of Western oil majors after 1973.

In the aftermath of the Oil Crisis, bilateral relations with the Middle East transformed and foreign policy moved towards a pro-Arab diplomatic stance, distancing itself from Israel. Japanese development banks and senior ministers also agreed loans to Iraq and other oil-producing countries in exchange for oil, as securing oil supplies became a key policy objective in Tokyo. ${ }^{62}$

Throughout the 1970s and early 1980s Japanese firms, supported by the Japanese government, aggressively sought stakes in projects around the world - including those in countries such as Iran and the Soviet Union - despite objections from its traditional post-war ally the USA. As discussed in Section 3, the results of these efforts were mixed, but they have been referred to as the first example of a Japanese foreign policy response independent from the USA in the post-war period. ${ }^{63}$

\footnotetext{
${ }^{59}$ Yukiko Miyagi and Yoshikazu Kobayashi, 'Japan's Energy Policy and Energy Diplomacy in the Gulf,' in The Emerging Middle East-East Asia Nexus ed. Yukiko Miyagi and Anoushiravan Ehteshami (London: Routledge, 2015); Namie Tsujigami and Koji Horinuki, 'Japan in the Gulf - between Intra-Bureaucratic Politics and Inter-Asian Rivalry,' ibid.

60 Tsurumi (1976) provides evidence that actual supply disruptions and reductions in oil imports incurred during the First Oil Crisis were grossly misreported by Japanese policymakers for political purposes.

${ }^{61}$ Yukiko Miyagi, 'Japan's Pursuit of Gulf Energy Resources: Between US Dependence and Asian Competition,' in Converging Regions: Global Perspectives on Asia and the Middle East, ed. Charlotte Schriwer and Nele Lenze (Farnham: Routledge 2014).

62 ibid

63 ibid.
} 

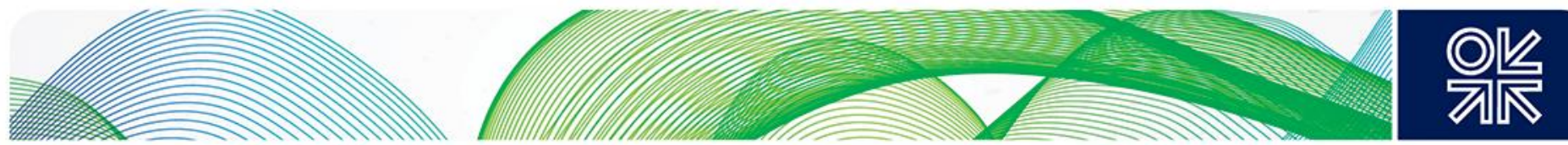

Figure 20: Oil imports by company type 1973-2014 (Million kilolitres)

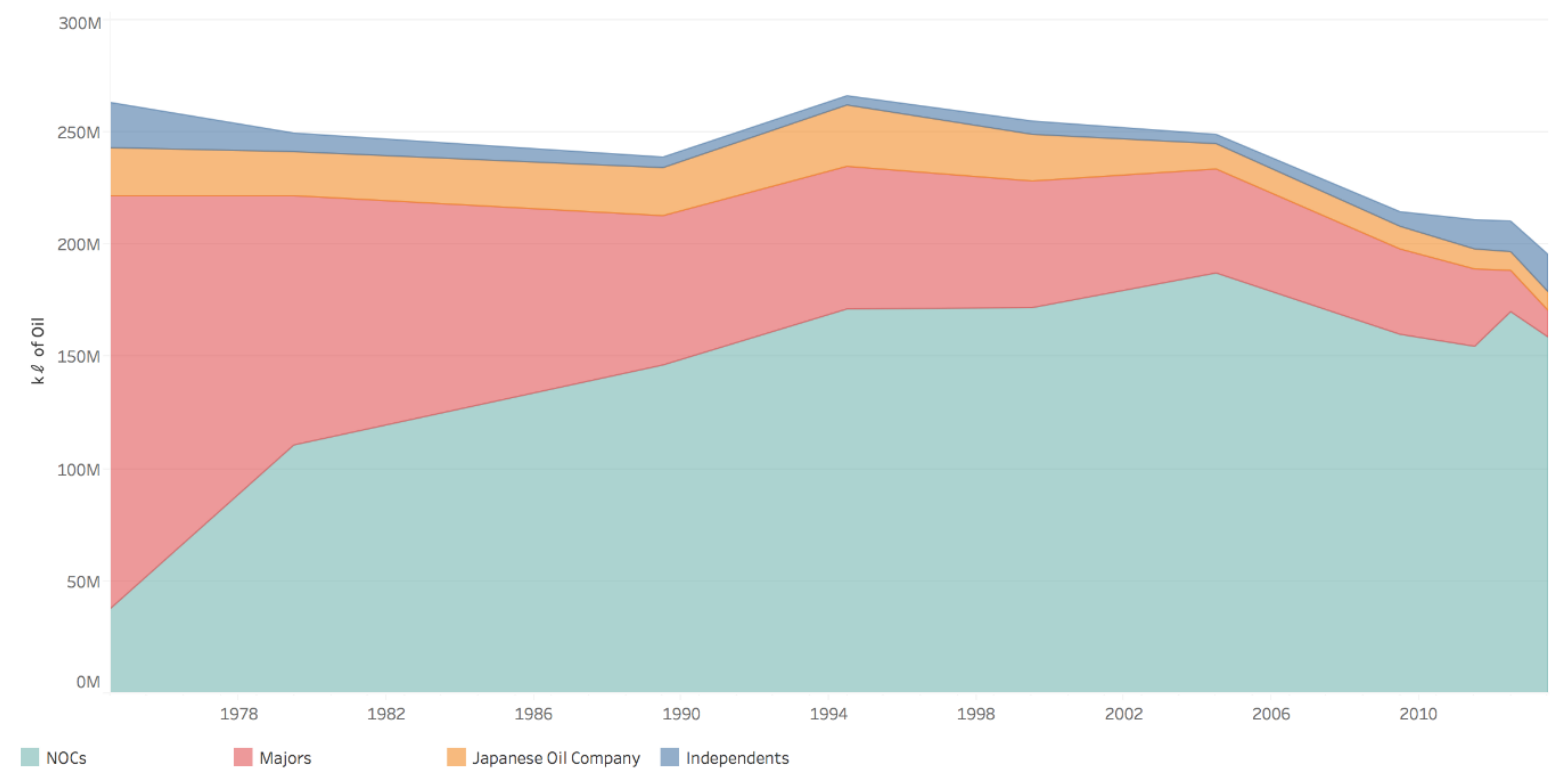

Source: Petroleum Association of Japan (2015)

Note: 'Independents' refers to both foreign independent oil companies and Japanese trading companies.

\subsection{Second phase of resource diplomacy towards the Middle East}

From the mid-1980s, imports from China, Indonesia, Mexico, and other non-Middle Eastern markets decreased and so Japan's reliance on Middle Eastern imports increased. However, this coincided with the period of low global oil prices and relative abundance of oil seen in the 1980s. Japan and the Middle Eastern producers started to recognize their interdependent relationship and the benefits of supply stability. Japanese economic assistance continued, and during major conflicts such as the Iran-Iraq War, Japan sought to protect its investments through bilateral engagement while maintaining neutrality towards the conflicting sides and encouraging multilateral diplomatic initiatives (through the United Nations, for example) to end the conflict. ${ }^{64}$

The relative abundance of oil at low prices resulted in a decrease of rushed resource diplomacy (such as had been seen in the immediate aftermath of the First Oil Crisis) and the sense of energy insecurity retreated. Economic cooperation with the Middle East continued, however, but Japanese foreign policy again became increasingly aligned with US foreign policy in the region. In the 1980s, Japan started to distance itself from Iran and, later, from Iraq as Saddam Hussain fell out of favour with the US leadership at the time. On the other hand, engagement with GCC states started to increase.

\footnotetext{
${ }^{64}$ Shintaro Abe, then foreign minister and father of current Prime Minister Shinzo Abe, visited Iran and Iraq in 1983 in an attempt to prevent escalations of the Iran-Iraq war and to protect Japanese investments. At the time of the visit, Japan imported $10 \%$ of its oil from Iran, while Iraq was the most important overseas market for Japanese construction companies and a significant market for machinery.
} 

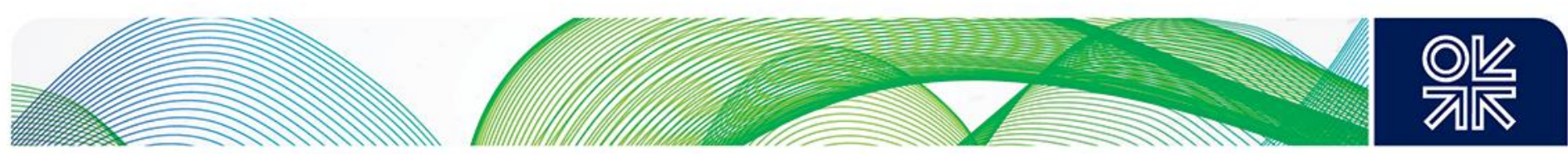

\subsection{Third phase of resource diplomacy towards the Middle East}

In the 1990s, Japan recognized that it was not the only Asian buyer of crude oil in the Middle East nor the only provider of capital goods. China turned from being a net oil exporter to a net oil importer in 1993, and emerging economies in Asia rapidly increased their purchases of oil. In light of this, concerns about supply disruptions in the Middle East were supplemented by security threats closer to home in east Asia (countries like China and North Korea), worries on chokepoints in Asia (such as the Strait of Malacca), and later by market disruptions like the Chinese oil demand shock in the 2000s. ${ }^{65}$

As oil prices started to climb again in the mid-2000s, a notable increase in diplomatic visits to the Middle East and a strengthening of resource diplomacy followed. ${ }^{66}$ Adding to rising oil prices, a failure to renew Japanese concessions in KSA and Kuwait and to reach an agreement with Iran on developing the Azadegan field, forced Japan to diversify and expand its approach in the Middle East attempts were made to strengthen ties through an approach coined 'technology-for-oil'.

This period (late 1990s and early 2000s) also coincided with two conservative Japanese governments that aligned the country's foreign policy very closely to that of the USA, and included the first major deployment of Japanese troops to the Middle East in 2003 as part of the invasion of Iraq. ${ }^{67}$ Accordingly, Japanese engagement with Middle Eastern oil producers who also fell under the US security umbrella (such as KSA, Kuwait, Qatar, and the UAE) increased.

The only real exceptions to the alignment of Japanese resource diplomacy with US foreign policy were the continuation of crude oil imports from Iran and attempts by Japanese firms in the 2000s to develop the Azadegan project in Iran. Oil imports from Iran, however, decreased in the 2000s as Japan gave in to a combination of US and international pressure to disengage with Iran.

\subsection{Towards a multilateral resource diplomacy}

Since the 2000s, resource diplomacy has transformed into what is referred to as 'multilateral resource diplomacy'; this includes diplomatic, economic, and private engagement with oil producers and is not exclusive to the oil and gas sectors. Japanese ministries such as METI and MOFA have coordinated their efforts and strategies following previous setbacks - such as the loss of concessions in KSA and Kuwait, and the failure to develop the Azadegan field in Iran. METI has also introduced a New National Energy Strategy that calls for the involvement of key government institutions - such as the Japan Bank for International Cooperation (JBIC) and NEXI - to assist oil-producing countries in diversifying their oil-dependent economies. ${ }^{68}$

Reflecting this policy change, high-level visits by ministers, monarchs, and private companies between the Middle East and Japan have increased, and the promotion of Japanese businesses has been strengthened through the establishment of trade missions. The Japanese government has also continued to offer economic packages that involve large-scale business contracts, allowing numbers of both public and private companies to participate in fields that have been identified as significant for Japanese interests, such as infrastructure. ${ }^{69}$

\footnotetext{
65 Tsutomu Toichi, 'Hajime Ni [in Japanese] [Introduction],' (Tokyo: The Japan Institute for International Affairs, 2016); METI, 'Enerugi Ni Kan Suru Nenjihoukoku [in Japanese] [Annual Report on Energy].'

${ }^{66}$ Foreign minister Kono visited Saudi Arabia, UAE, Kuwait, and Qatar in 2000 and called for a 'dialogue among civilization' to facilitate understanding of history and culture. Yukiko Miyagi. 'Japan's Pursuit of Gulf Energy Resources: Between US Dependence and Asian Competition.'

67 In 1996, Japan dispatched a limited number troops for peace keeping operations in the Golan Heights.

68 Tsujigami and Horinuki.

${ }^{69}$ Abe visited Saudi Arabia, the UAE, Kuwait, and Qatar in 2006 and sealed agreements (with KSA) to expand cooperation beyond the energy field. Furthermore, joint committees on economic cooperation were established with the UAE, Kuwait, and Qatar. PM Abe visited the UAE and Saudi Arabia again in 2013. Yukiko Miyagi. 'Japan's Pursuit of Gulf Energy Resources: Between US Dependence and Asian Competition.
} 

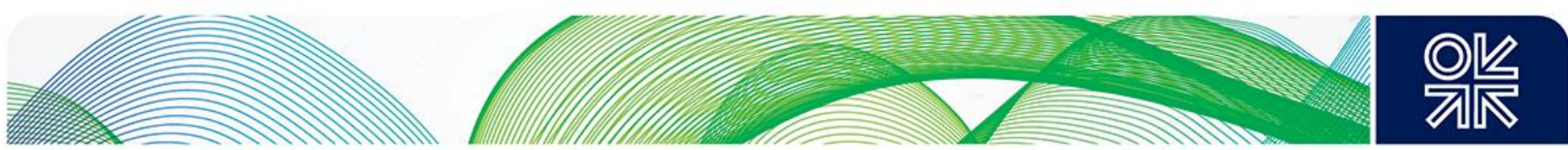

The multilateral approach and the move away from simple imports of oil solve two issues at the same time:

- The procurement of oil and gas is facilitated.

- Business opportunities for Japanese firms are opened up.

Multilateral resource diplomacy fundamentally seeks to outgrow business relations that are solely confined to energy and to extend them to other fields.

The outlook for Japan's resource diplomacy is dependent on considerations such as current relations with oil producers, future oil demand, US foreign policy, and economic and security cooperation in Asia. These considerations will be summarized in Section 7 .

\section{Japanese involvement in oil projects in the Middle East}

In this section, we will provide an overview of the involvement and investments of Japanese oil companies in the Middle East. For the sake of structuring the review, countries are reviewed in the order: Gulf Cooperation Council states, Iran, and Iraq.

Figure 21 below reveals a breakdown of the sources of Japan's imports from the Middle East and how they have evolved over time. Major trends are:

- The gradual increase of KSA and UAE imports.

- Decreased imports from Iran and other countries in the Middle East and North Africa (such as Libya).

- Decreased imports from the Kuwait-KSA Neutral Zone, due to the loss of Japan's AOC concession in the year 2000 .

Figure 21: Oil imports from the Middle East (million litres) - 1960-2015

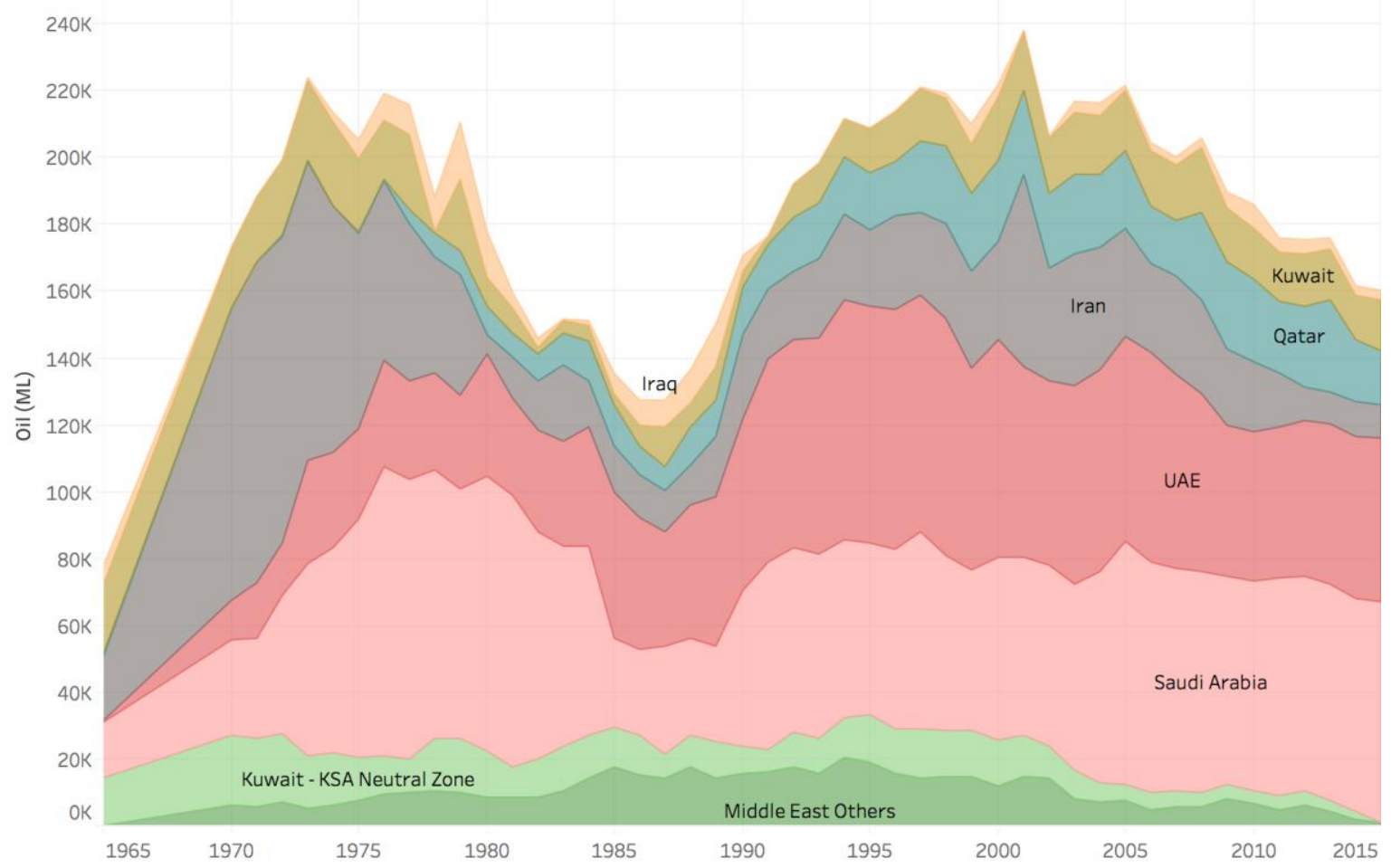

Source: EDMC (2017) 

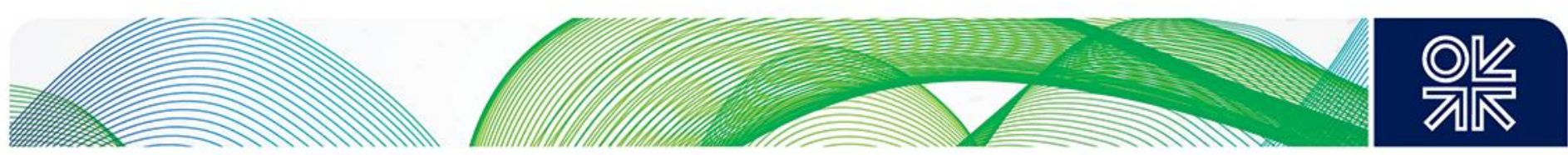

$\mathrm{KSA}$, along with the UAE, stand out as the most important suppliers of crude to Japan and as the countries where the level of multilateral engagement is most notable. As both states fall within the US security framework, Japanese policymakers and firms have faced no major political obstacles from the USA towards investments, and investment activities increased as competition for oil resources intensified from other Asian importers in the 1990s and 2000s. Today, Japan is the second-largest export market for Saudi Arabia and the third for the UAE, reflecting the economic interdependency of the countries. ${ }^{70}$

\subsection{Saudi Arabia}

The first foreign oil concessions that Japan acquired in the post-war period were in the Neutral Zone between KSA and Kuwait (in the al-Khafaji, al-Hout, and Lulu fields) and exports to Japan started in 1961. The Japanese operator, AOC, lost the concessions in the Saudi part in 2000, and in the Kuwaiti part in 2002; Japanese oil companies currently have no direct stakes in oil fields in KSA, although they have cooperated in downstream projects. ${ }^{71}$ Despite this loss of concessions, the share of KSA oil in the Japanese oil mix has been increasing and stood at 37.4 per cent in 2016, as exports of light crude and Arab extra light have increased to Japanese customers who were willing to pay a premium to ensure stable supply during recent OPEC production cuts. ${ }^{72}$ Saudi Aramco's business in Japan is also not confined to supplying oil, as the firm has a footprint in the downstream sector through its investment in Showa Shell, and the Kingdom of Saudi Arabia holds a stake in the minor downstream player Fuji Oil. ${ }^{73}$ Saudi Aramco also leases 8.2 million barrels (Mb) of storage capacity in Okinawa and half of the oil is treated as Japan's quasi-governmental strategic petroleum reserve (SPR). ${ }^{74}$

On the diplomatic front, there has been no shortage of interaction between Japan and KSA, or of statements under the broad exchange of 'technology for oil'. In 2007, the Japan-Saudi Taskforce was established to further investments, human resource development, and support for SMEs from both countries in a wide range of sectors. Japan has also attempted to contribute to human resource development and to assist Saudi Arabia in its 'Saudization' programme. ${ }^{75}$ In 2016. Crown Prince Mohammed bin Salman led a delegation from Saudi Arabia to meet with Japan's political and business elites, followed by another visit in 2017 together with King Salman. ${ }^{76}$ During the 2016 visit, more than $20 \mathrm{MOUs}$ on various projects were signed. Following the announcement of Vision 2030, the 'Saudi-Japan Vision 2030' was introduced; this outlines future investments and economic cooperation, such as on special economic zones for Japanese firms in Saudi Arabia. More recently, the Public Investment Fund of the Kingdom of Saudi Arabia made a large investment in Softbank's USD93bn Vision Fund that is being spearheaded by Japanese billionaire Masayoshi Son. ${ }^{77}$

Despite the flurry of statements and activities, the fact that the Saudi-Japan Vision 2030 forum is driven by governments and not by private businesses must be taken into account; it therefore remains to be seen if private businesses will follow into KSA. Japanese manufacturers in particular are reluctant to set up manufacturing facilities in KSA, having taken into account perceived labour

\footnotetext{
70 Source: JETRO, 'State of Qatar,' (Tokyo: JETRO, 2017).

71 Sumitomo Chemical Project in Rabigh, KSA and other downstream and petrochemical projects.

72 Reuters, 'Saudi Arabia Tightens Its Grip on Japan, Its Biggest Asian Oil Market,' (2017).

${ }^{73}$ Shareholders include: Kuwait Petroleum Corporation (7.43\%); Government of the Kingdom of Saudi Arabia (7.43\%); Showa Shell (6.57\%).

74 The storage needs to be at least half filled and in times of emergency Japan has a priority claim to the stockpiles. Osamu Tsukimori, 'Japan to Raise Crude Storage Capacity for Saudi Aramco in Okinawa,' World Oil,

http://www.worldoil.com/news/2017/7/7/japan-to-raise-crude-storage-capacity-for-saudi-aramco-in-okinawa.

75 Tsujigami and Horinuki; Satoru Nakamura, 'Challenges for Qatar and Japan to Build Multilayered Relations,' (Doha: Gulf Studies Center, Qatar University, 2016).

${ }^{76}$ Deputy Crown Prince at the time of the visit in August and September 2016.

77 METI, 'Nihon No Enerugi to Chuto Shokoku - Antei Kyokyu Ni Muketa Kokusaiteki Na Torikumi [in Japanese] [Japanese Energy and the Middle East - an International Arrangement Towards Stable Supply],' in Enerugi Anzen Hoshyo - Supesyaru Kontentsu (METI, 2017).
} 

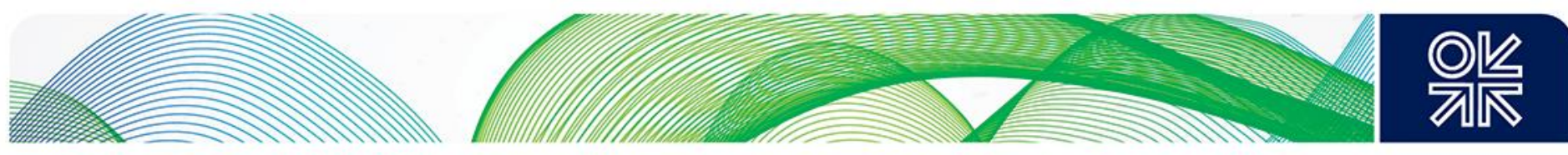

productivity issues, local content rules, lack of supply chains, and the relatively small domestic market. ${ }^{78}$ Secondly, the notion of China as an anchor investor in the upcoming Saudi Aramco IPO has troubled policymakers and the media in Japan and could temporarily dampen Japanese enthusiasm for investments in the Kingdom. However, despite these challenges the level of activity cannot be overlooked, and considering factors such as the size of the Japanese economy, its generally pragmatic economic policy, and the lack of historical baggage in the Arab World make the country a natural fit in Saudi Arabia's ambitious Vision 2030. ${ }^{79}$

\subsection{United Arab Emirates}

When it comes to the acquisition and extension of overseas oil-producing assets, the United Arab Emirates are by far the most important partner for Japan, and the place where oil firms' interests mostly lie. The Abu Dhabi offshore concession was the first that Japan acquired in the Emirates (in 1978), through its former national oil project company JODCO; this concession is now held by INPEX. The UAE represents one of the few areas in the world where Japanese oil firms have access to lowcost-high-reserve plays, and 40 per cent of Japanese overseas concessions are currently located in the UAE. Of these concessions, 40 per cent were extended in January 2017, and agreement on these extensions was considered a high-level priority within government in Japan. According to METI, the successful extensions were attributed to a coordinated multilateral use of what can best be classified as resource diplomacy. Negotiations for the extension of the remaining 60 per cent of the concessions (ADMA-OPCO, scheduled to expire in March 2018) are underway, and a visit by PM Abe scheduled for 2018 reflects the importance that Japanese policymakers assign to the UAE. Japanese downstream player JXTG is also expected to join the negotiations, concurrent with planning to build a refining and petrochemical complex in Abu Dhabi to meet increased demand for refined products in the Emirates and as a part of a strategy to diversify out of Japan. ${ }^{80}$

While some Japanese firms hold stakes in the UAE, overall reliance on the UAE is highest at INPEX and Cosmo Oil. Table 4 below demonstrates Japanese project involvement in the UAE.

\section{Table 4: Projects in the United Arab Emirates}

\begin{tabular}{|l|l|l|l|}
\hline Owner & Main Partner & Block & Share \\
\hline \multirow{4}{*}{ INPEX - JODCO } & ADNOC & Satah & $40 \%$ \\
\cline { 3 - 4 } & & Umm Al-Dalkh & $12 \%$ \\
\cline { 2 - 4 } & \multirow{3}{*}{ ADNOC, BP, Total } & ADCO & $5 \%$ \\
\cline { 3 - 4 } & & Lower Zakum & $12 \%$ \\
\cline { 3 - 4 } & & Umm Lulu & $12 \%$ \\
\cline { 3 - 4 } & & Umm Shaif & $12 \%$ \\
\cline { 2 - 4 } & ADNOC, ExxonMobil & Upper Zakum & $12 \%$ \\
\hline \multirow{2}{*}{ Cosmo Oil } & \multirow{2}{*}{ JX } & Mubarraz & $64 \%$ \\
\cline { 3 - 4 } & & Neewat Al-Ghalan & $64 \%$ \\
\cline { 3 - 4 } & & Umm Al-Anbar & $64 \%$ \\
\hline
\end{tabular}

\footnotetext{
78 Source: Senior oil analyst in Tokyo, interview with author on 25 October 2017.

${ }^{79}$ Nikkei, 'Japan Inc. Signs on to Saudi's Quest for Diversified Economy,' Nikkei Asian Review, https://asia.nikkei.com/PoliticsEconomy/International-Relations/Japan-Inc.-signs-on-to-Saudis-quest-for-diversified-economy?page=2. Giorgio Cafiero et al., 'Japan's Important Role in Saudi's Vision 2030,' (2016), http://www.mei.edu/content/article/future-riyadh-tokyo-relations. 80 Jennifer Gnana, 'Energy Year in Review: Middle East Oil Majors Gain Optimism,' The National (2017), https://www.thenational.ae/business/energy/energy-year-in-review-middle-east-oil-majors-gain-optimism-1.689618; METI, 'METI and ADNOC Concluded a Basic Agreement on the Extension of Japanese Company's Oil Concessions on the Satah and Umm Al Dalkh Oilfields Offshore from Abu Dhabi That the Company Has Possessed for Forty Years'; Nikkei, 'Japan's JXTG Weighs Investment in Abu Dhabi Petrochemical Project', Nikkei Asian Review, 9 November 2017.
} 

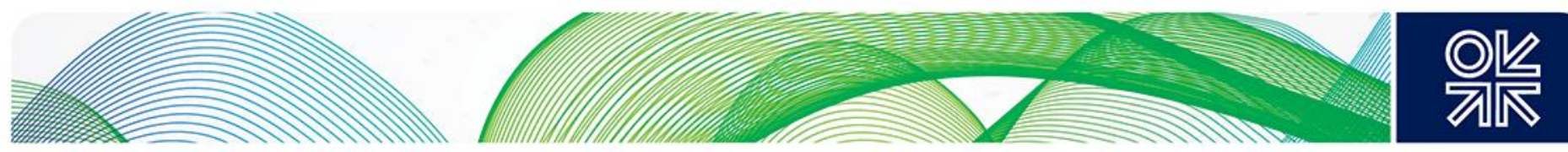

\begin{tabular}{|c|c|c|c|}
\hline \multirow[t]{3}{*}{ JX } & \multirow[t]{3}{*}{ Cosmo Oil } & Mubarraz & $32 \%$ \\
\hline & & Neewat Al-Ghalan & $32 \%$ \\
\hline & & Umm Al-Anbar & $32 \%$ \\
\hline \multirow[t]{3}{*}{ Kansai Electric } & \multirow[t]{3}{*}{ Cosmo Oil } & Mubarraz & $2 \%$ \\
\hline & & Neewat Al-Ghalan & $2 \%$ \\
\hline & & Umm Al-Anbar & $2 \%$ \\
\hline \multirow[t]{3}{*}{ Chubu Electric } & \multirow[t]{3}{*}{ Cosmo Oil } & Mubarraz & $2 \%$ \\
\hline & & Neewat Al-Ghalan & $2 \%$ \\
\hline & & Umm Al-Anbar & $2 \%$ \\
\hline
\end{tabular}

Source: Company websites

The investment arm of the Abu Dhabi government, International Petroleum Investment Company (IPIC), holds a stake in downstream player Cosmo Oil, as well as holding a share in Cosmo Oil's upstream assets in the UAE. Similar to Saudi Aramco's position in Okinawa, Abu Dhabi National Oil Company (ADNOC) has leased 6.3 Mb of storage capacity in Kagoshima in southern Japan that is counted as part of Japan's quasi-governmental SPR. Currently, Saudi Aramco and ADNOC are the only NOCs in Japan to have such agreements in place with the Japanese state.

Japan and the UAE have signed MOUs in the field of energy, education, medicine, and technology, among others. Secondly, JOGMEC has entered into a memorandum of cooperation with the UAE on strategic business development in the upstream, midstream, and downstream sectors, including the entry of new markets in Asia. ${ }^{81}$ The oil storage facility in Kagoshima and its stake in Cosmo Oil may serve a stepping stone for these purposes, according to industry insiders. Outside of oil, the UAE represents an important market for Japanese infrastructure, construction, and heavy industrial firms such as Mitsubishi Heavy Industries, Kawasaki Heavy Industries, Taisei, and the trading company Marubeni. Currently, the largest number of Japanese firms in the Middle East is located in the UAE, and the Japanese expatriate population in the UAE is also the largest in the Middle Eastern region.

\subsection{Qatar}

Qatar was the third-largest supplier of oil (9 per cent) and LNG (15 per cent, or 12.06 metric tons per annum (mtpa)) in 2016 to Japan. ${ }^{82}$ Oil imports from Qatar started in the 1980s, and LNG deliveries in 1996 as Chubu Electric (a major utility company in Japan) became the first customer to sign a longterm LNG purchase agreement (4 mtpa) with Qatar and its nascent LNG industry in 1992. ${ }^{83}$ Japan, the largest LNG importer in the world, is Qatar's top export partner and the majority of trade is concentrated on oil and gas. ${ }^{84}$ Unlike the cases of KSA and the UAE, the importance of the LNG business outweighs that of oil, and the relationship is rooted in pragmatism and a deep national interest. ${ }^{85}$ Accordingly, relations are stronger between Japan's traditional buyers of LNG (utilities and trading companies) and Qatar than those with oil companies.

Japanese oil companies do hold stakes in oil projects in Qatar although the scale is limited compared to the UAE. Tables 5 and 6 demonstrate Japanese involvement in projects in Qatar and Abu DhabiQatar offshore.

\footnotetext{
${ }^{81}$ METI, 'Nihon No Enerugi to Chuto Shokoku - Antei Kyokyu Ni Muketa Kokusaiteki Na Torikumi [in Japanese] [Japanese Energy and the Middle East - an International Arrangement Towards Stable Supply].'

${ }^{82}$ Source: METI 'Enerugi Ni Kan Suru Nenjihoukoku [in Japanese] [Annual Report on Energy].'; IGU, '2017 World LNG Report,' (Barcelona: International Gas Union, 2017).

${ }^{83}$ Nakamura.

${ }^{84}$ JETRO, 'State of Qatar,' (Tokyo: JETRO, 2017).

${ }^{85}$ Cinzia Miotto and Giorgio Cafiero, 'The Prospects for Japanese-Qatari Relations,' Atlantic Council (2016),

http://www.atlanticcouncil.org/blogs/menasource/the-prospects-for-japanese-qatari-relations.
} 

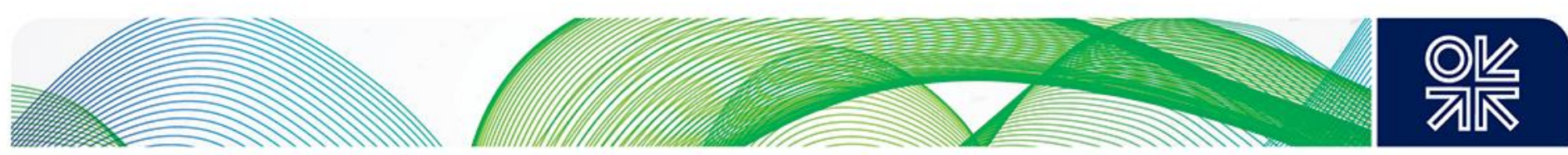

Table 5: Projects in Qatar

\begin{tabular}{|l|l|l|l|}
\hline Owner & Main Partner & Block & Share \\
\hline Cosmo Oil & Sojitz & Qatar Offshore Block 1SE (AI Karkara) & $75 \%$ \\
\hline Mitsui Oil Development & Qatar Petroleum, Total & Qatar Northwest Offshore & $3 \%$ \\
\hline Sojitz & Cosmo Oil & Qatar Offshore Block 1SE (AI Karkara) & $25 \%$ \\
\hline
\end{tabular}

Source: Company websites

Table 6: Projects in Abu Dhabi -Qatar offshore

\begin{tabular}{|l|l|l|l|}
\hline Owner & Main Partner & Block & Share \\
\hline \multirow{2}{*}{ JX } & $100 \%$ JX & Block A (Pre-Khuff) & $100 \%$ \\
\cline { 2 - 4 } & Cosmo Oil & Bunduq & $45 \%$ \\
\hline Mitsui Oil Development & JX/Cosmo Oil & Bunduq & $10 \%$ \\
\hline Cosmo Oil & JX & Bunduq & $45 \%$ \\
\hline
\end{tabular}

Source: Company websites

Japanese firms played a significant role in creating the LNG business in Qatar and in developing the North Field (discovered in 1971). Marubeni took a 7.5 per cent stake in Qatargas 1 in 1984, to support LNG marketing in Japan, and Mitsui also holds a 7.5 per cent equity stake. Additionally, the Japanese export banks and credit insurance agencies (today's JBIC and NEXI) provided financing and credit insurance for the project, Chiyoda Corporation provided EPC services, and Chubu Electric was the sole LNG off-taker. Mitsui, Marubeni, Itochu, and Cosmo Oil also participated in later projects such Qatargas 3 and the Las Raffan Refinery Project Company (trains 1 and 2). LNG Japan - a JV between Sumitomo and Sojitz - holds a 3 per cent stake in the Las Raffan LNG project. ${ }^{86}$ Japanese utility companies such as Chubu and Tepco have all entered into a number of long-term LNG purchase agreements with Qatar that tie them to the market until the 2030s. The complicated nature of LNG projects and the need to coordinate a large number of stakeholders (such as long-term offtakes and government banks) is an area where tier-one trading companies such as Mitsui were historically at an advantage, compared to oil projects that are more dependent on the operator's experience, technology, and balance sheet strength.

In non oil and gas-related fields, the Japan-Qatar Economic Forum has been held regularly since 2006; Japanese major construction firms such as Taisei and Takenaka are involved in Qatar and the ongoing construction of the Doha Metro is led by a consortium of Mitsubishi Heavy Industries, Hitachi, and Kinki Sharyo. ${ }^{87}$ In the ongoing Qatar Diplomatic Crisis, PM Shinzo Abe has called both the Emir of Qatar and Crown Prince Mohammad bin Salman to voice the Japanese stance. This represents a departure from Japanese 'passenger seat' diplomacy and a move towards a more assertive policy. Secondly, rumoured attempts to drive Japan away from Qatar might prove difficult given its dependence on Qatari LNG. ${ }^{88}$

There are, however a number of challenges on the horizon for Japan-Qatar relations. First, with the emergence of LNG purchasing companies such as JERA (a JV between Chubu Electric and Tepco), Japanese buyers have pressed hard to renegotiate long-term LNG purchase contracts and destination clauses. Secondly, the development and start of operations of large-scale LNG plants in Australia being led by INPEX are expected to decrease Japanese reliance on Qatari LNG and alter

\footnotetext{
${ }^{86}$ Qatargas, 'Corporate Structure,' Qatargas, http://www.qatargas.com/english/aboutus/corporate-structure.

${ }^{87}$ Mitsubishi, 'Five Member Consortium of Mitsubishi Heavy Industries, Mitsubishi Corporation, Hitachi, Kinki Sharyo and

Thales Receives Letter of Conditional Acceptance for Doha Metro Construction,' news release, 20 February 2015 ,

https://www.mitsubishicorp.com/jp/en/pr/archive/2015/html/0000026741.html.

${ }^{88}$ Source: Senior oil analyst in Tokyo, interview with author on 25 October 2017.
} 

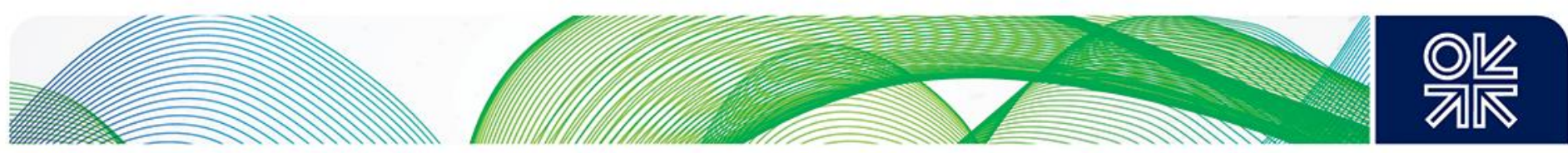

the predominant role of trading and utility companies in the Japanese LNG market. LNG exports from the USA would further hasten the decrease in reliance on Qatar. ${ }^{89}$

\subsection{Other Gulf Cooperation States: Kuwait and Oman}

\section{Kuwait}

Kuwait supplies more than 7 per cent of Japan's crude oil and the now disbanded oil company (AOC) held a concession in the Kuwaiti part of the Neutral Zone until 2002. Japanese firms have not been directly involved in projects in Kuwait since the loss of the AOC concession, and the relationship is mostly confined to oil imports. Despite the sizeable amount of Kuwaiti exports to Japan, its oil company (Kuwait Petroleum Corporation) has a limited presence in Japan - a 7 per cent equity stake in downstream minor Fuji Oil. The only other notable oil-related involvement between Kuwait and Japan is the recently established joint venture by downstream player Idemitsu with Kuwait Petroleum Corporation in Vietnam, on oil refining and marketing.

\section{Oman}

Oman plays a very limited role in oil as it only supplies around 1 per cent of Japanese imports. Oman, however, supplies 3 per cent of LNG imports and the trading company Mitsui has been active in LNG projects in recent years. Other trading companies, such as Itochu, Mitsui, and utility company Osaka Gas, have also invested in the Oman LNG Project as minority shareholders (3 per cent each in train 3), whereas Mitsui and Mitsubishi each hold a 3 per cent share and Itochu a 1 per cent share in trains 1 and $2 .{ }^{90}$

Table 7 shows Japanese participation in LNG projects in Oman:

Table 7: Projects in Oman

\begin{tabular}{|l|l|l|l|}
\hline Owner & Main Partner & Block & Share \\
\hline \multirow{3}{*}{ Mitsui Oil Development } & OCCED & Block 3\&4 & $20 \%$ \\
\cline { 2 - 4 } & \multirow{2}{*}{ Occidental } & Block 9 & $5 \%$ \\
\cline { 3 - 4 } & & Block 27 & $35 \%$ \\
\hline Itochu & Oman LNG/Government of Oman & Muscat & $3 \%$ \\
\hline Mitsubishi & Oman LNG/Government of Oman & Muscat & $3 \%$ \\
\hline Osaka Gas & Oman LNG/Government of Oman & Muscat & $3 \%$ \\
\hline
\end{tabular}

Source: Company Websites

The former national oil companies (INPEX, JAPEX) and private oil companies have no presence in Kuwait or Oman.

\subsection{Iran}

While KSA is currently the largest supplier of oil to Japan today, Iran held that role until the First Oil Crisis. In 1953, following the nationalization of the Iranian oil industry and despite objections from the Anglo-Iranian Oil Company, Idemitsu imported its first cargo directly from Iran. The incident caused a

\footnotetext{
89 Jonathan Stern, 'The New Japanese LNG Strategy: A Major Step Towards Hub-Based Gas Pricing in Asia,' Oxford Energy Comment (Oxford: Oxford Institute for Energy Studies 2016); Tom Finn and Oleg Vukmanovic, 'Qatar Talks Tough on Project Stakes in Japan LNG Contract Talks,' Reuters (2017), https://www.reuters.com/article/us-qatar-japan-Ing/exclusive-qatar-talkstough-on-project-stakes-in-japan-Ing-contract-talks-idUSKBN18Q1W3.

90 Oman LNG Development Foundation, 'Oman LNG Development Foundation,' (Muscat: Oman LNG Development

Foundation, 2017); Japan Petroleum Development Association, Wagakuni Sekiyu Tennen Gasu Kaihatsu No Genjyo to Kadai [The state of affairs of oil and natural gas issues in Japan] (Tokyo: Japan Petroleum Development Association, 2017).
} 

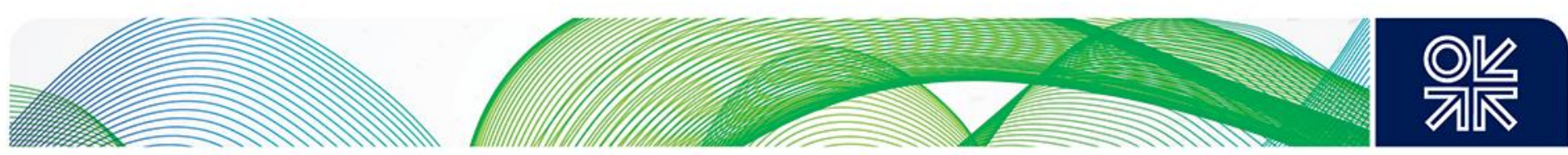

diplomatic dispute between Japan and the UK, but regardless of that, imports from Iran rose to 41 per cent of imports by 1971. Iranian imports still accounted for more than 20 per cent until the Iranian Revolution, but decreased during the Iran-Iraq War and then again later, due to economic sanctions and US pressure. In recent years, Iran's share has hovered between 5 and 8 per cent. ${ }^{91}$

Japanese involvement in Iran has been heavily strained by its relationship with the USA, and when major tensions flared between the USA and Iran, both in 1979 and 2002, Japanese private companies had significant interests in Iran. ${ }^{92}$ In 1971, Iran became home to the largest Japanese overseas investment at the time as, with the strong support of the Japanese government, Mitsui launched a JV (the Iran Japan Petrochemical Company, or IJPC) with the National Iranian Oil Company (NIOC). However, Mitsui left the project after it was devastated by heavy Iraqi bombardment during the IranIraq War. ${ }^{93}$ In 1999, following the discovery of the Azadegan oil field, President Khatami offered a privileged position to Japan to develop the USD2bn project. INPEX took a 75 per cent per cent stake in the project in 2004, with the intention of developing it. After considerable Iranian frustration over delays, problems with clearing landmines from the Iran-Iraq War, outstanding issues with the production sharing contract, and pressure from the USA, INPEX's share was reduced to 10 per cent in $2004 .{ }^{94}$ In 2010, INPEX returned its remaining 10 per cent share to NIOC to avoid itself being subject to either US sanctions or limitations in financing its operations in other markets, due to immense pressure from the USA to make the Azadegan deal and Japan-Iranian relations subject to Iran's compliance on nuclear issues. INPEX's sunk projects costs were estimated at USD153m. ${ }^{95}$

Despite the risks and the bitter experience of the Iran Japan Petrochemical Company, the idea of participating in the Azadegan project proved enticing to METI, as it would have allowed Japanese firms to increase their upstream assets, secure the long-term flow of oil into Japan, and increase the SDR. The failure to develop the project was a disappointment to METI especially, since it came after the loss of Japanese concessions in KSA and Kuwait in 2000 and 2002. Today, the only project with direct Japanese ownership in Iran is Saroosh-Nowrooz, a formerly JNOC majority-owned buy-back project, where JAPEX still holds a 20 per cent share. ${ }^{96}$

Tokyo has maintained amicable relations with Tehran in recent years, but the declining importance of Iran is showing. PM Shinzo Abe has yet to visit Iran, despite numerous visits to neighbouring countries, and any speculation that the Iranian government has collaborated with North Korea on its nuclear programme is an exceptionally thorny issue in Japan. ${ }^{97}$ Following the removal of international economic sanctions on Iran in 2016 INPEX, along with other oil companies, entered negotiations and submitted technical proposals in preparation for a bid on the development of the Azadegan field. ${ }^{98}$ However, the delay of the bid, previous experience (coupled with the election of Donald Trump as US president), and severe security concerns on North Korea have raised questions on the real willingness of INPEX and its largest shareholder (the Japanese state) to get involved in the project. It must be taken into account that INPEX, with the strong support of METI and MOFA, is also in the midst of negotiations in Abu Dhabi on the extension of its existing concessions. Considering these conditions, together with the strained relationship between the UAE (and KSA) and Iran, it is unlikely that either INPEX or other Japanese firms will pursue interests in Iran at any cost.

\footnotetext{
91 EDMC

92 Yukiko Miyagi. 'Japan's Pursuit of Gulf Energy Resources: Between US Dependence and Asian Competition.

93 ibid.

${ }^{94}$ As the conditions of the Azadegan agreement became clearer the attractiveness of the project decreased to both the Japanese government and INPEX.

95 Vlado Vivoda, Energy Security in Japan: Challenges after Fukushima (London: Routledge, 2014); Reuters, 'Japan's INPEX Quits Iran Azadegan Oilfield Project,' (2010).

96 Japan Petroleum Development Association; JAPEX, 'Annual Report 2006,' (Tokyo: JAPEX, 2006). Up to date information on the project is limited in either JAPEX's annual report or other published materials.

${ }_{97}$ Nikkei, 'Could Iran Be Behind North Korea's Nuclear, Missile Advances?,' Nikkei Asian Review,

https://asia.nikkei.com/Spotlight/North-Korea-crisis/Could-Iran-be-behind-North-Korea-s-nuclear-missile-advances

98 Platts, 'Former Operator INPEX Considers Bidding for Iran's Azadegan Oil Field,' (2017).
} 

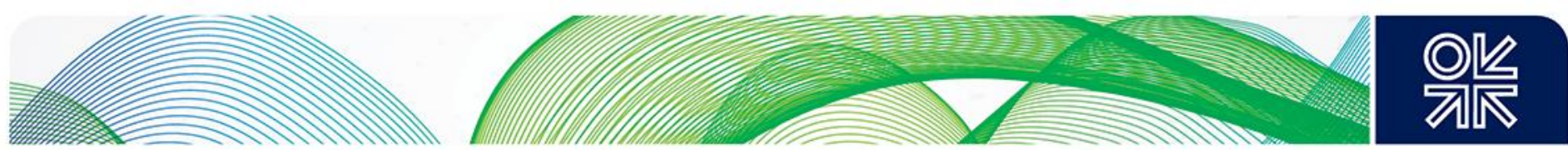

Despite the failure of both IJPC and the Azadegan project, Japanese long-term interest in Iran is strong and not only in the energy field. With the third-largest population in MENAT (Middle East, North Africa, and Turkey), a large domestic market, and the need for investment in infrastructure and various businesses, the Iranian market has potential and should be attractive if political normalization takes place in Iran. In reality, Japanese interest in post-sanctions Iran was largely stifled by the election of President Donald Trump in November 2016. On manufacturing, Turkey or south-east Europe may be more feasible options as manufacturing bases, and so firms can be expected to be very cautious about investing in Iran. Furthermore, both Japanese firms and the state are well aware of the need to balance their relationships and interests between Iran and Saudi Arabia. ${ }^{99}$

\subsection{Iraq}

The importance of Iraq as an oil supplier is currently limited to less than 2 per cent of Japan's total imports. In the 1970s, Japan provided financing for various projects in Iraq - such as a thermal power plant, an oil refinery, and a fertilizer plant - in exchange for oil, and a number of these projects involved Mitsubishi. During the Iran-Iraq War, Japan maintained a neutral position despite the bombardment of its assets in Iran, but Japan gave up its oil interests in Iraq in the 1990s because of strong US pressure. Attempts to re-establish oil relations with Iraq in the post-Gulf War period were thwarted by the USA, which wished to replace the Ba'ath regime in Iraq. ${ }^{100} \mathrm{At}$ the time of the 2003 invasion of Iraq, Japan had little or no economic interest in Iraq. Japanese policymakers believed that a US-supported regime in Iraq would go unopposed in the Middle East, thus re-opening oil opportunities for Japanese businesses in Iraq. ${ }^{101}$

Japanese support for the 2003 invasion of Iraq was contingent on a UN resolution; in the absence of such a resolution and with an understanding of the opposition to the war in the Arab World, Japanese support was mainly confined to post-war recovery, logistical support, and humanitarian assistance. 102 The resumption of Iraq-Japan relations was slow in the 2000s, considering the domestic security situation in Iraq, and Japanese policymakers overestimated the opportunities available in Iraq. In 2009, Iraq-Japan relations gained momentum as JAPEX, JOGMEC, and Mitsubishi were awarded a combined stake ( 30 per cent) in the Garraf project in southern Iraq, together with Petronas and the North Oil Company. INPEX also struck oil, in 2017, in the Onshore Block 10 project in the vicinity of Basra, together with operator Lukoil. ${ }^{103}$

Table 8 shows Japanese participation in LNG projects in Iraq:

Table 8: Projects in Iraq

\begin{tabular}{|l|l|l|l|}
\hline Owner & Main Partner & Block & Share \\
\hline INPEX & Lukoil & Onshore Block 10 & $40 \%$ \\
\hline Japex & Petronas, North Oil Corporation & Garraf & $17 \%$ \\
\hline JOGMEC & Petronas, North Oil Corporation & Garraf & $11 \%$ \\
\hline Mitsubishi & Petronas, North Oil Corporation & Garraf & $3 \%$ \\
\hline
\end{tabular}

Source: Company Websites

\footnotetext{
99 Shigeru Sudou, 'Perusyawangansyokoku No Enerurgi Jijyo to Nihon No Enerugi Senryaku [in Japanese] [the State of Energy Affairs in the Persian Gulf and Japanese Energy Strategy],' (Tokyo: The Japan Institute for International Affairs, 2016).

100 Yukiko Miyagi, 'Japan's Pursuit of Gulf Energy Resources: Between US Dependence and Asian Competition.'

101 Yukiko Miyagi, ‘Japan's Middle East Policy: “Still Mercantile Realism”,' International Relations of Asia-Pacific 12 (2012): 304.

102 Japanese business delegations led by government officials have visited Iraq on numerous occasions since the end of the war in Iraq, JICA opened offices in Erbil and Baghdad. However, real investment has been limited due to poor security in Iraq Yukiko Miyagi, 'Japan's Pursuit of Gulf Energy Resources: Between US Dependence and Asian Competition.'

103 JAPEX, 'Corporate Report.'; INPEX, 'INPEX Succeeds in Oil Discovery at Onshore Exploration Block 10, Iraq,' news release, 22 February 2017, http://www.inpex.co.jp/english/news/pdf/2017/e20170222.pdf.
} 

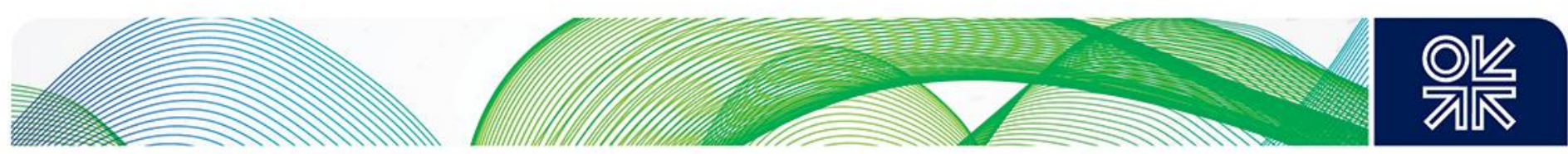

In 2017, Iraq-Japan relations entered a new stage as the Japan Bank for International Cooperation (JBIC), together with Mitsubishi and Sumitomo, resumed loans to Iraq for power plants, after a 31 year absence from the country. ${ }^{104}$ Considering the recent oil discoveries involving JAPEX and INPEX, and Mitsubishi's involvement in oil trade and the Basra Gas Company Project, the role played by Iraq as an oil supplier to Japan can be expected to increase in upcoming years. ${ }^{105}$

\section{Outlook for Japan and oil}

In this paper, we have established that oil import dependency in Japan and reliance on the Middle East will continue for the foreseeable future. However, oil consumption is projected to drop from current levels of $4 \mathrm{Mb} / \mathrm{d}$ to $2.5 \mathrm{Mb} / \mathrm{d}$ by 2040 according to IEA estimates, while other observers expect that Japan will turn into a $2 \mathrm{Mb} / \mathrm{d}$ market with a $2.3 \mathrm{Mb} / \mathrm{d}$ refining capacity by 2030 . This would represent a significant decrease in the importance of the Japanese market for exporters; it also raises questions on the logic behind, and the necessity for, Japanese oil development policy. ${ }^{106}$ We will now outline the implications of these developments, and provide concluding remarks on the future direction of the Japanese oil industry at the industry level, policy level, and from the viewpoint of oilproducing countries attempting to maintain their market share in Japan.

\subsection{Oil industry structure and strategy}

The market is still fragmented when compared to NOC or IOC-dominated markets, but a shrinking market has significantly brought down the number of players. The division between the upstream and downstream sectors remains an enduring market feature, but major players such as INPEX, Mitsui, Mitsubishi, and JXTG have firmly claimed stakes in their respective segments. There is still little indication that an upstream-downstream merger can be expected; such a merger would create a sizeable Japanese integrated oil company on a par with Italy's ENI (cited as a model for the Japanese oil industry). ${ }^{107}$ Decreased market size and squeezed margins may bring this development around in due course.

The Japanese oil industry is, however, adjusting to the decline of the domestic market and so the following developments can be expected:

- In the upstream oil and gas sectors, INPEX will continue to play a role as a core company, as the largest Japanese producer of oil and gas. INPEX and other upstream players can be expected to apply a concentrated regional focus in key areas that are open to Japanese upstream investments, such as the UAE, Iran, and, Iraq. However, given the relatively limited competitive advantage of Japanese oil companies, a continued pattern of minority investments in oil projects can be expected by all market players. To tackle the lack of competitive advantage, an increased focus on complex LNG and FLNG can be expected as a future source of competitive advantage to be leveraged both in oil and gas project acquisition. While coordination between the Japanese state and former national oil companies (such as INPEX and JAPEX) can be expected, it should not be taken for granted when considering the future strategies of downstream players (such as JXTG, Cosmo Oil, and, Idemitsu) that may have stakes in the upstream sector.

\footnotetext{
${ }^{104}$ Nikkei, 'After 31 Years, Japan to Resume Loaning to Iraq,' Nikkei Asian Review, https://asia.nikkei.com/PoliticsEconomy/Policy-Politics/After-31-years-Japan-to-resume-loaning-to-Iraq.

105 The Basra Gas Company aims to export stranded natural gas (such as that currently being flared) to neighbouring Kuwait for LNG liquefaction. Salam Zidane, 'Iraq Has Much to Gain from Gas-Supply Pact with Kuwait,' Al-Monitor, http://www.almonitor.com/pulse/originals/2018/01/iraq-gas-kuwait-oil-field.html.

${ }^{106}$ Osamu Tsukimori and Aaron Sheldrick, 'Japan oil refinery consolidation ends dominant era in oil markets,' Reuters, (2016), Published electronically 16 February 2016. http://www.reuters.com/article/us-global-oil-idUSKBN1AQ01H

${ }^{107}$ Takeo Kikkawa, Nihon Sekiyu Sangyo No Kyosouryoku Kochiku [The Competitiveness and Structure of the Japanese Oil Industry] (Nagoya: Nagoya Daigaku Shuppankai, 2012).
} 

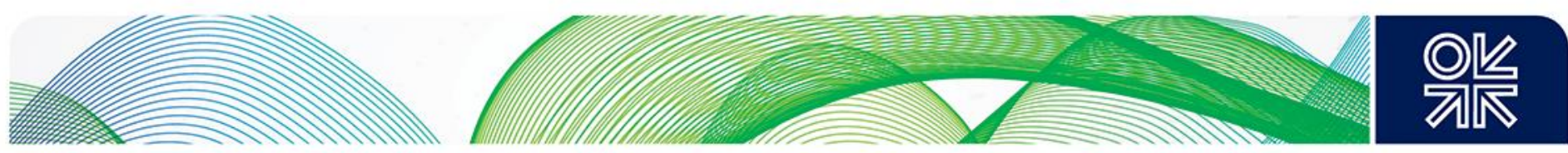

- The downstream sector is in a slow decline, when viewed through refining capacity, but business unit diversification is moving rapidly across the industry. Further industry consolidation (such as the ongoing but troubled Idemitsu-Showa Shell merger), reduced refining capacity, and cooperation in oil procurement through strategic alliances are all viewed as necessary. ${ }^{108}$ It is, however, difficult to foresee interest by downstream players in merging with upstream players such as INPEX or JAPEX, considering their long-term aversion to government intervention. Secondly, the low-margin nature of the Japanese downstream sector should be of limited interest to trading companies such as Mitsui or Mitsubishi, despite potential synergies with their upstream divisions and downstream players. Rather, continued independence from Japanese upstream players can be expected. It is more likely that downstream players will leverage their access to the Japanese market and relative ease of access to high-growth markets in Asia-Pacific (such as those in Vietnam, Thailand, the Philippines, and Australia) through tie-ups with NOCs that seek downstream know-how and experience. Finally, a strengthening of trading operations in Singapore (JXTG and Idemitsu) and elsewhere in Asia has already started, and according to one insider, downstream players may be pursuing a pan-Pacific marketing and refining network, in line with Valero Energy's strategy and business model in North America, the UK, and Ireland. ${ }^{109}$

\subsection{A more rational oil development policy and policy towards the Middle East}

Today, Japanese resource diplomacy and oil development support stand at a crossroads. Decreases in oil demand have made it politically difficult to justify pursuing upstream interests at any cost. Secondly, higher levels of economic interdependence and cooperation with producers in the Middle East, which are highly dependent on stable exports to Asia, have raised questions on the logic of Japan attempting to increase its self-development ratio of oil under the pretext of energy security. A re-evaluation of assumptions made in the early 1970s on how to assure oil security is overdue, and METI's next Strategic Energy Plan (expected in summer 2018) will most likely question the feasibility of self-development oil. Regarding the role of JOGMEC, oil development policy, and Japanese resource diplomacy towards the Middle East, the following developments can be expected:

- The future role of JOGMEC in research and development and information to stakeholders in Japan's oil industry is clear, but its role in oil project acquisition is rather ambiguous. As outlined in Section 3, JOGMEC support for overseas oil projects is limited when compared to its predecessor (JNOC), and while its risk money budget for overseas acquisitions was increased in FY 2016, no major acquisitions have been made. ${ }^{110}$ JOGMEC can now work directly with foreign governments or NOCs and it is no longer restricted to indirectly supporting Japanese projectspecific companies. The corporation aims to make sizeable investments that would award it a seat on the board of large oil and gas projects, and it does not intend to act as an operator. Its support does not, however, change the reality that the successful acquisition of overseas assets at reasonable prices is not only dependent on government support (whether through JOGMEC or $\mathrm{JBIC}$ ), but on the operational and technological strengths of its oil companies and the value they bring to their partners. It is likely that a JOGMEC failure to directly acquire overseas assets in the short run will raise questions on the need for JOGMEC to do so at all. ${ }^{111}$

\footnotetext{
${ }^{108}$ Akio Makabe, 'Enen to Naibu Koso Wo Tsudukeru Idemitsu Wo, Toushika Ga Migakirihajimeta [in Japanese] [as the Internal Conflict Continues at Idemitsu, Investors Start to Leave],' Business Journal, 9 January 2018.

109 Source: Industry insider, interview with the author on 29 October 2017 in Tokyo.

${ }^{110}$ Budget increase for operations JPY12bn for 2017 fiscal year and JPY150bn for investment and support purposes.

111 In 2016, when a proposal in the House of Representatives of the Japanese Diet was made to increase JOGMEG's budget and risk money, concerns were raised on what kind of measures were being taken to avoid a reputation of losses and governance issues like those seen at JNOC. The current Minister of Economy, Trade and Industry Hiroshige Seko assured the government that adequate governance and due diligence measures were in place to avoid a repetition of JNOC's losses and governance failure. Committee on Economy; Trade and Industry, 'Sekiyu Tensen Gasu Kinzoku Kobutsu Shigen Kikou (JOGMEC) Hou [in Japanese] [Jogmeg Law],' in Committee on Economy; Trade and Industry, House of Representatives (2016).
} 

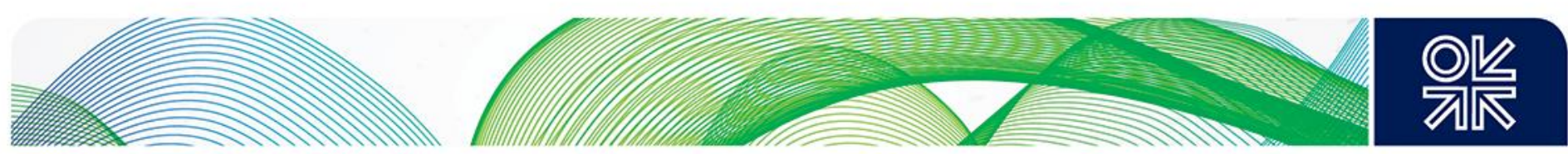

- Government support for overseas development is still guided by the objective of increasing Japan's self-development ratio of oil and gas from the current levels of 27 per cent to 40 per cent by 2030 . However, both the level of support and the 'shotgun' approach to project acquisition came under severe scrutiny in the 2000s. Therefore, a policy of concentrated support in selected markets (where resource diplomacy can be leveraged) together with limiting the number of Japanese oil companies (such as INPEX, JAPEX, Mitsui, and Mitsubishi) involved is highly likely. In the case of the Middle East and oil, this essentially confines support to the UAE, Iran, and Iraq. While the relevance of oil is declining in Japan, the country is faced with competition from other Asian countries such as China and South Korea. Japan also stands at a disadvantage as arms sales to sweeten deals, or Chinese-style directives against private companies, are largely off the table. There is, however, a clear indication that Japanese policymakers and oil companies are synchronizing their efforts more successfully. This is demonstrated in the ongoing negotiations with the UAE, where INPEX, JOGMEC, JXTG, METI, MOFA, JBIC, and NEXI are all involved in multilateral resource diplomacy, and this may be an indication of Japan's future approach to oil development.

- Japanese oil involvement in the Middle East is still largely consistent and explainable, through the foreign policy constraints of Japan's reliance on the USA for its security. Saudi Arabia and the United Arab Emirates are the pillars of Japanese supply security. In other countries, such as Kuwait, the relationship is confined to oil imports, whereas Mitsui and other trading companies have been active in the LNG business in Oman, just as they were in Qatar in the 1990s. Iraq still plays a limited role as a supplier, but recent discoveries and the potential for expanded production will surely not go unnoticed by the Japanese oil industry. In the case of Qatar, Japan has access to the lowest-cost gas in the world, but as the Japanese LNG purchasing landscape changes (with the emergence of players such as JERA and the start of operations of Japanese majorityowned FLNG projects such as the Ichthys project - with an expected production of 8.9 mtpa of LNG) the role of Qatar may decline. Finally, the real intentions of INPEX and the Japanese state in Iran may simply be to provide leverage in negotiations with the UAE, and to form part of the indirect pressure on KSA to prevent or mitigate the prospects of China as an anchor investor in the much-anticipated IPO of Saudi Aramco.

\subsection{How will oil producers ensure their market share in Japan?}

One final consideration: what are the implications of a shrinking market for oil producers and how will they ensure their market share in Japan? There is no denying that Japan is a sunset market in the oil sector, but at slightly less than $4 \mathrm{Mb} / \mathrm{d}$ it is still a large market, and for that matter one that is perceived as a premium market by oil producers. Unlike the situation in the gas sector, no large oil procurement company that follows the same pattern as JERA has yet emerged. Accordingly, oil producers that can reliably supply the correct class of API and sulphur content crude compatible with Japanese refinery configurations, can rely on captive customers. Japan's main suppliers, KSA and UAE, face limited actual risks that Japanese buyers will switch suppliers or diversify their supplies in the mid-term, as such a move would be met with resistance from refineries. Pressure by METI or JOGMEC to diversify away from KSA and UAE is also unlikely to materialize, due to the lack of realistic economic alternatives. Attempts to force private companies to purchase more expensive crude, considering transportation costs, from west Africa, would also be met with resistance.

Regardless of the low chances of supplier switching, Japan's main suppliers of crude have taken measures to fortify their positions in the market. Most notably, Saudi Aramco and ADNOC have made agreements with the Japanese government to store crude in Okinawa and Kagoshima. The crude is stored for commercial purposes, but in the case of an emergency, Saudi Aramco and ADNOC are required to prioritize deliveries to Japan. The Japanese government counts half of these reserves as part of their SPR, and in 2016 this accounted for four days' worth of the 208-day SPR. ${ }^{112}$ By

\footnotetext{
112 Petroleum Association of Japan.
} 

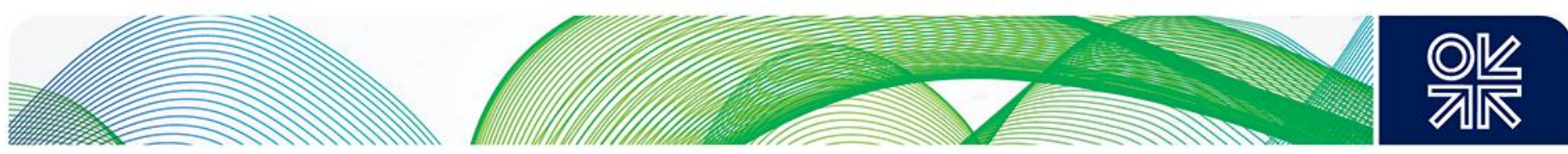

cooperating with NOCs, Japanese policymakers are attempting to increase market liquidity by encouraging firms to rent oil storage for trading. For oil producers, oil storage in southern Japan has opened up the option of small-scale deliveries to the so-called 'teapot refineries' in neighbouring China that may otherwise have been unable to purchase full loads from VLCC (Very large crude carriers), due to credit restrictions and long lead times. ${ }^{113}$ The NOCs and governments of Saudi Arabia and the UAE have also invested in Japanese downstream players Showa Shell, Cosmo Oil, and Fuji Oil, thereby further cementing their stake in Japan. On the assumption that the IdemitsuShowa Shell merger goes through, Saudi Aramco would hold an equity stake in a new player with approximately 25 per cent of Japan's crude refining capacity; this could, furthermore, be used as a springboard for downstream operations in other Asian markets such as Vietnam. For other oil producers in the Gulf, a decrease in Japanese purchases or increased discounts may be expected, together with the loss of what is considered a premium customer. However, robust demand in China and India will make up for decreased exports to Japan, and the position should stabilize in the long run.

In conclusion, Japanese policymakers, and METI in particular, have been too concerned about supply disruptions and have overlooked the Gulf's export dependence on Japan and Asia in recent years. The days of the Japanese oil development policy 'at any cost' are over, and the future path of Japanese oil investments will lead to an increased role for oil firms in the decision-making process and a departure from policies that are driven primarily by oil security and dictated by METI. While the role of the state in oil markets is still undeniably large, this represents a healthier relationship between the Japanese state and its oil firms. Japanese oil firms need the freedom to outgrow state support, seek upstream opportunities compatible with their strategies, and compete on the basis of their competitive advantage and access to the still large Japanese market. Oil producers in the Middle East dealing with Japanese players can also expect more rational counterparties who are aligned with IOC strategies to a greater extent, rather than the oil-obsessed Japan of the past.

\footnotetext{
${ }^{113}$ Michal Meidan, 'China's Independent Refineries: A New Force Shaping Global Oil Markets,' in Energy Insights (Oxford: Oxford Institute for Energy Studies, 2017).
} 

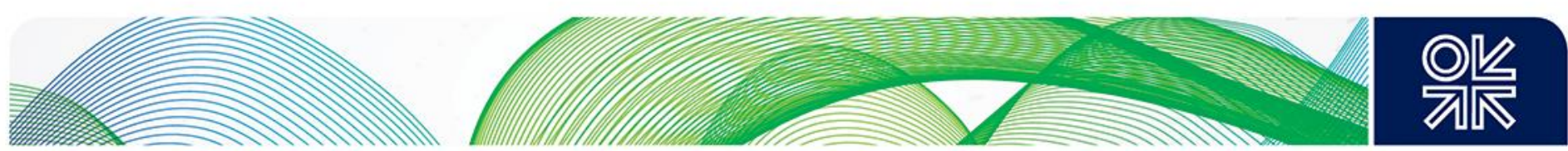

\section{Bibliography}

BP. 'BP Statistical Review of World Energy'. BP, 2017.

Cafiero, Giorgio, Theodore Karasik, Cinzia Miotto, and Daniel Wagner. 'Japan's Important Role in Saudi's Vision 2030.' (2016). Published electronically 29 December 2016. http://www.mei.edu/content/article/future-riyadh-tokyo-relations.

Chrisstoffels, Jan-Hein. 'Getting to Grips Again with Dependency: Japan's Energy Strategy.' Hague: Clingendael International Energy Programme CIEP, 2007.

Committee on Economy, Trade, and Industry. 'Sekiyu Tensen Gasu Kinzoku Kobutsu Shigen Kikou (JOGMEC) Hou [in Japanese] [Jogmeg Law].' In Committee on Economy; Trade and Industry, House of Representatives, 2016.

Cosmo Oil. 'Cosmo Energy Holdings Cosmo Report 2017.' Tokyo: Cosmo Energy Holdings, 2017.

Duffield, John. 'Fuels Paradise: Seeking Energy Security in Europe, Japan, and the United States. Baltimore: John Hopkins University Press, 2015.

EDMC. EDMC Handbook of Japan's \& World Energy \& Economic Statistics. Tokyo: The Energy Conservation Center, Japan, 2017.

Finn, Tom and Oleg Vukmanovic. 'Qatar Talks Tough on Project Stakes in Japan LNG Contract Talks.' Reuters (2017). Published electronically 31 May 2017.

https://www.reuters.com/article/us-qatar-japan-Ing/exclusive-qatar-talks-tough-on-projectstakes-in-japan-Ing-contract-talks-idUSKBN18Q1W3.

Flath, David. The Japanese Economy. 3rd Edition ed. Oxford: Oxford University Press, 2014.

FOC. 'Annual Report 2017.' Tokyo: Fuji Oil Company, Ltd., 2017.

Gnana, Jennifer. 'Energy Year in Review: Middle East Oil Majors Gain Optimism.' The National (2017). Published electronically 21 December 2017.

https://www.thenational.ae/business/energy/energy-year-in-review-middle-east-oil-majorsgain-optimism-1.689618.

Green, Joseph. 'First LNG Tanker Arrives at the Soma LNG Terminal.' LNG Industry (2017). Published electronically 7 December 2017. https://www.Ingindustry.com/liquid-naturalgas/07122017/first-Ing-tanker-arrives-at-the-soma-Ing-terminal/.

Hughes, Llewelyn. Globalizing Oil: Firms and Oil Market Governance in France, Japan, and the United States. Cambridge: Cambridge University Press, 2014.

Idemitsu. 'Annual Report.' Tokyo: Idemitsu Kosan Co. Ltd., 2017.

IEA. 'Energy Policies of IEA Countries Japan 2016 Review.' Paris: IEA, 2016.

IGU. '2017 World LNG Report.' Barcelona: International Gas Union, 2017.

INPEX. 'Annual Report 2017.' Tokyo: INPEX Corporation, 2017.

'INPEX Succeeds in Oil Discovery at Onshore Exploration Block 10, Iraq.' news release, 22 February 2017, http://www.inpex.co.jp/english/news/pdf/2017/e20170222.pdf.

Itochu. 'Annual Report 2017.' Tokyo: Itochu Corporation, 2017.

Japan Petroleum Development Association. Wagakuni Sekiyu Tennen Gasu Kaihatsu No Genjyo to Kadai [in Japanese] [The state of affairs of oil and natural gas issues in Japan]. Tokyo: Japan Petroleum Development Association, 2017.

JAPEX. 'Annual Report 2006.' Tokyo: JAPEX, 2006.

'Corporate Report.' Tokyo: JAPEX, 2017.

JETRO. 'State of Qatar.' Tokyo: JETRO, 2017. 

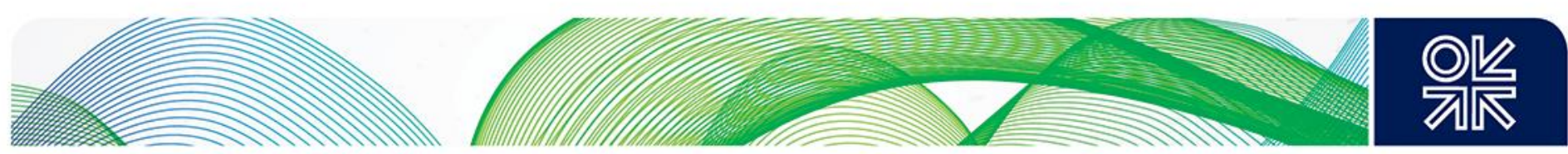

JOGMEC. 'Omo Na Shien Purojekuto [in Japanese] [Main Projects under JOGMEC Support].' JOGMEC, http://www.jogmec.go.jp/oilgas/financial_004.html.

.'Renketsu Fuzoku Meisaisho [in Japanese] [Consolidated Supplementary Statements].' Tokyo: JOGMEC, 2017.

JXTG. 'JXTG Report Sogou Report 2017 [in Japanese] [JXTG Consolidated Report 2017].' Tokyo: JXTG, 2017.

Kikkawa, Takeo. Nihon Sekiyu Sangyo No Kyosouryoku Kochiku [in Japanese] [The Competitiveness and Structure of the Japanese Oil Industry]. Nagoya: Nagoya Daigaku Shuppankai, 2012.

Sekiyu Sangyo No Shinjitsu [in Japanese] [The Truth About the Oil Industry]. Tokyo: Sekiyu Tsushin, 2015.

Koike, Masanari, Gento Mogi, and Waleed H. Albedaiwi. 'Overseas Oil-Development Policy of Resource-Poor Countries: A Case Study from Japan.' Energy Policy 36, no. 5 (2008): 176475.

Makabe, Akio. 'Enen to Naibu Koso Wo Tsudukeru Idemitsu Wo, Toushika Ga Migakirihajimeta [in Japanese] [as the Internal Conflict Continues at Idemitsu, Investors Start to Leave].' Business Journal, 9 January 2018.

Manning, Robert A. The Asian Energy Factor: Myths and Dilemmas of Energy, Security and the Pacific Future. London: Palgrave Macmillan, 2000.

Marubeni. 'Marubeni Kabushikigaisha Sougou Hokokusho 2017 [in Japanese] [Marubeni KK Consolidated Report 2017].' Tokyo: Marubeni Corporation, 2017.

Meidan, Michal. 'China's Independent Refineries: A New Force Shaping Global Oil Markets.' In Energy Insights. Oxford: Oxford Institute for Energy Studies, 2017.

METI. 'Enerugi Ni Kan Suru Nenjihoukoku [in Japanese] [Annual Report on Energy].' Tokyo: METI, 2017.

'METI and ADNOC Concluded a Basic Agreement on the Extension of Japanese Company's Oil Concessions on the Satah and Umm Al Dalkh Oilfields Offshore from Abu Dhabi That the Company Has Possessed for Forty Years.' METI, http://www.meti.go.jp/english/press/2017/0116_002.html.

_.'Nihon No Enerugi to Chuto Shokoku - Antei Kyokyu Ni Muketa Kokusaiteki Na Torikumi [in Japanese] [Japanese Energy and the Middle East - an International Arrangement Towards Stable Supply].' In Enerugi Anzen Hoshyo - Supesyaru Kontentsu: METI, 2017.

'Sogo Shigen Kansakai Bunkakai, Sekiyuseisaku Shoinkai [in Japanese] [Report of Policy Subcommittee of Petroleum Committee, Advisory Committee for Energy].' Tokyo: METI, 2006.

Miotto, Cinzia, and Giorgio Cafiero. 'The Prospects for Japanese-Qatari Relations.' Atlantic Council (2016). Published electronically 2 June 2016.

http://www.atlanticcouncil.org/blogs/menasource/the-prospects-for-japanese-qatari-relations.

Mitsubishi. '2017 Nendo Dainihanki Ir Shiryo [in Japanese] [2017 H2 Investor Relations Documents].' Tokyo: Mitsubishi Corporation, 2017.

.'Five Member Consortium of Mitsubishi Heavy Industries, Mitsubishi Corporation, Hitachi, Kinki Sharyo and Thales Receives Letter of Conditional Acceptance for Doha Metro Construction.' news release, 20 February 2015 , https://www.mitsubishicorp.com/jp/en/pr/archive/2015/html/0000026741.html.

Mitsui. '2018 Nen 3 Gatsuki Dainisihanki Kessai Setsumei Shiryo [in Japanese] [Financial Report Documents for the 2nd Half of Fiscal Year Ending in March 2018].' Tokyo, 2017.

'Completion of the Acquisition of Santos' Interest in an Offshore Gas and Condensate Field in Australia.' Mitsui, https://www.mitsui.com/jp/en/release/2016/1218623_8910.html. 

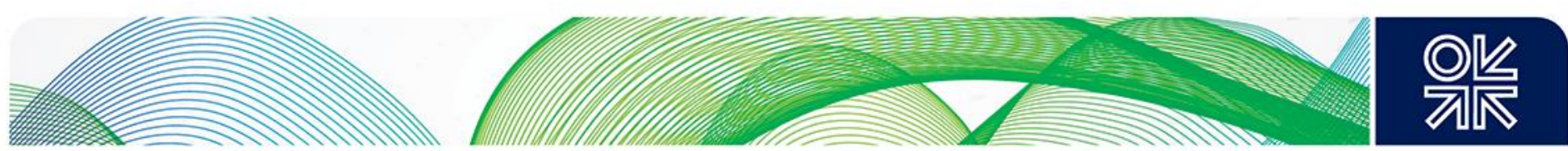

Miyagi, Yukiko. 'Japan's Middle East Policy: “Still Mercantile Realism”.' International Relations of AsiaPacific 12 (2012): 287-315.

.'Japan's Pursuit of Gulf Energy Resources: Between US Dependence and Asian Competition.' In Converging Regions: Global Perspectives on Asia and the Middle East, edited by Charlotte Schriwer and Nele Lenze. Farnham: Routledge 2014.

Miyagi, Yukiko and Yoshikazu Kobayashi. 'Japan's Energy Policy and Energy Diplomacy in the Gulf.' In The Emerging Middle East-East Asia Nexus edited by Yukiko Miyagi and Anoushiravan Ehteshami. London: Routledge, 2015.

Nakamura, Satoru. 'Challenges for Qatar and Japan to Build Multilayered Relations.' Doha: Gulf Studies Center, Qatar University, 2016.

Nikkei. 'After 31 Years, Japan to Resume Loaning to Iraq.' Nikkei Asian Review, 30 March 2017, https://asia.nikkei.com/Politics-Economy/Policy-Politics/After-31-years-Japan-to-resumeloaning-to-Iraq.

.'Could Iran Be Behind North Korea's Nuclear, Missile Advances?', Nikkei Asian Review, 26 September 2017, https://asia.nikkei.com/Spotlight/North-Korea-crisis/Could-Iran-be-behindNorth-Korea-s-nuclear-missile-advances.

'Japan Inc. Signs on to Saudi's Quest for Diversified Economy.' Nikkei Asian Review, 19 March 2017, https://asia.nikkei.com/Politics-Economy/International-Relations/Japan-Inc.signs-on-to-Saudis-quest-for-diversified-economy?page=2.

.Japan's JXTG Weighs Investment in Abu Dhabi Petrochemical Project', Nikkei Asian Review. 9 November 2017.

Oman LNG Development Foundation. 'Oman LNG Development Foundation.' Muscat: Oman LNG Development Foundation, 2017.

Petroleum Association of Japan. 'Konnichi No Sekiyu Sangyo [in Japanese] [the Oil Industry Today].' Petroleum Association of Japan, 2017.

—.'Petroleum Industry in Japan.' Tokyo: Petroleum Association of Japan, 2015.

Platts. 'Former Operator INPEX Considers Bidding for Iran's Azadegan Oil Field.' 30 May 2017.

Qatargas. 'Corporate Structure.' Qatargas, http://www.qatargas.com/english/aboutus/corporatestructure.

Reuters. 'Glencore sale of Rosneft stake earns rivals' respect, bankers' relief.' 12 September 2017.

.'Japan's INPEX Quits Iran Azadegan Oilfield Project.' 15 October 2010.

.'Saudi Arabia Tightens Its Grip on Japan, Its Biggest Asian Oil Market.' 6 July 2017.

Sankei. 'Hi No Maru Yuden Keneki Koshin Motomeru - Keizaisho, Abu Dhabi Homon He Kakuryo to Kousho [in Japanese] [a Visit by PM Abe Being Arranged with the Aim of Securing Japanese Oil Rights].' Sankei, 14 January 2017.

Showa Shell. 'Corporate Report 2017.' Tokyo: Showa Shell Sekiyu K.K., 2017.

Sojitz. 'Inquiry on Sojitz Daily Oil and Gas Production' by Loftur Thorarinsson, 13 December 2017.

Stern, Jonathan 'The New Japanese LNG Strategy: A Major Step Towards Hub-Based Gas Pricing in Asia.' Oxford Energy Comment. Oxford: Oxford Institute for Energy Studies June 2016.

Sudou, Shigeru 'Perusyawangansyokoku No Enerurgi Jijyo to Nihon No Enerugi Senryaku [in Japanese] [the State of Energy Affairs in the Persian Gulf and Japanese Energy Strategy].' Tokyo: The Japan Institute for International Affairs, 2016.

Sumitomo (Petro Summit). 'Petro Summit E\&P Corporation.' http://www.psep.tokyo.jp/company/history/.

Toichi, Tsutomu. 'Hajime Ni [in Japanese] [Introduction].' Tokyo: The Japan Institute for International Affairs, 2016. 

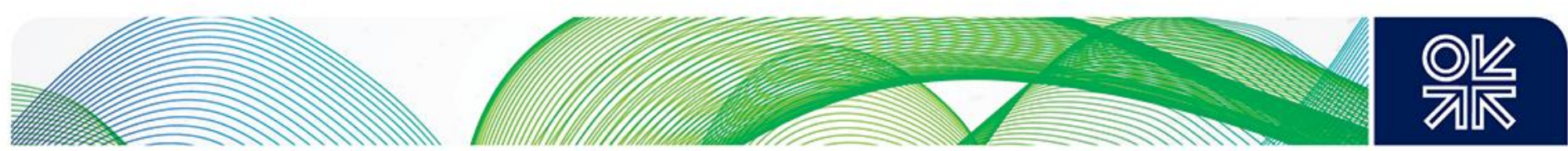

Tsujigami, Namie, and Koji Horinuki. 'Japan in the Gulf - between Intra-Bureaucratic Politics and Inter-Asian Rivalry.' In The Emerging Middle East-East Asia Nexus edited by Yukiko Miyagi and Anoushiravan Ehteshami. London: Routledge, 2015.

Tsukimori, Osamu. 'Japan to Raise Crude Storage Capacity for Saudi Aramco in Okinawa.' World Oil, http://www.worldoil.com/news/2017/7/7/japan-to-raise-crude-storage-capacity-for-saudiaramco-in-okinawa.

Tsukimori, Osamu and Sheldrick, Aaron. 'Japan oil refinery consolidation ends dominant era in oil markets,' Reuters, (2016), http://www.reuters.com/article/us-global-oil-idUSKBN1AQ01H

Tsurumi, Yoshi. 'Japan.' In The Oil Crisis, edited by Raymond Vernon, 113-27. New York: W.W. Norton \& Company Inc., 1976.

Vivoda, Vlado. Energy Security in Japan: Challenges after Fukushima. London: Routledge, 2014.

World Bank. 'World Development Indicators | Databank.' edited by World Bank, 2017.

Zen, Usoku. 'Nihon No Sekiyu Gasusangyo No Rekishi to Kozu - Kaihatsu Jigyou Wo Chusin Ni [in Japanese] [the Structure and History of the Japanese Oil and Gas Industry - a Study of Oil and Gas Development].' edited by Tetsuo Abo, 1-28. Kyoto: Minerva Shobo, 2008.

Zidane, Salam. 'Iraq Has Much to Gain from Gas-Supply Pact with Kuwait.' Al-Monitor, 7 January 2018, http://www.al-monitor.com/pulse/originals/2018/01/iraq-gas-kuwait-oil-field.html. 